\begin{tabular}{|l|l|}
\hline 2. To: (Receiving Organization) & 3. From: (Originating Organization) \\
East Tank Farms Transition & SGN Eurisys Services \\
Projects & Corporation \\
\hline 5. Proj./Prog./Dept./Div.: & 6. Design Authority/ Design Agent/Cog. \\
TWRS & R. S. Nichol son \\
\hline
\end{tabular}

8. Originator Remarks:

ETN-94-0010

for release)
3. From: (Originating Organization)
SGN Eurisys Services
Corporation
R. S. Nicholson

4. Related EDT No.:

609738

7. Purchase order No.:

N/A

9. Equip./Component No.: Hazleton $\mathrm{N}-20801$

10. System/Bldg./Facility: 241-AN-107

12. Major Assm. Dwg. No.: $\mathrm{H}-2-85264$

ATP performed in early FY 96 . Release of ATR delayed to FY 97 due to unexpected funding cut in FY 96
$N / A$

13. Permit/Permit Application No.: sponse Date: $N / A$

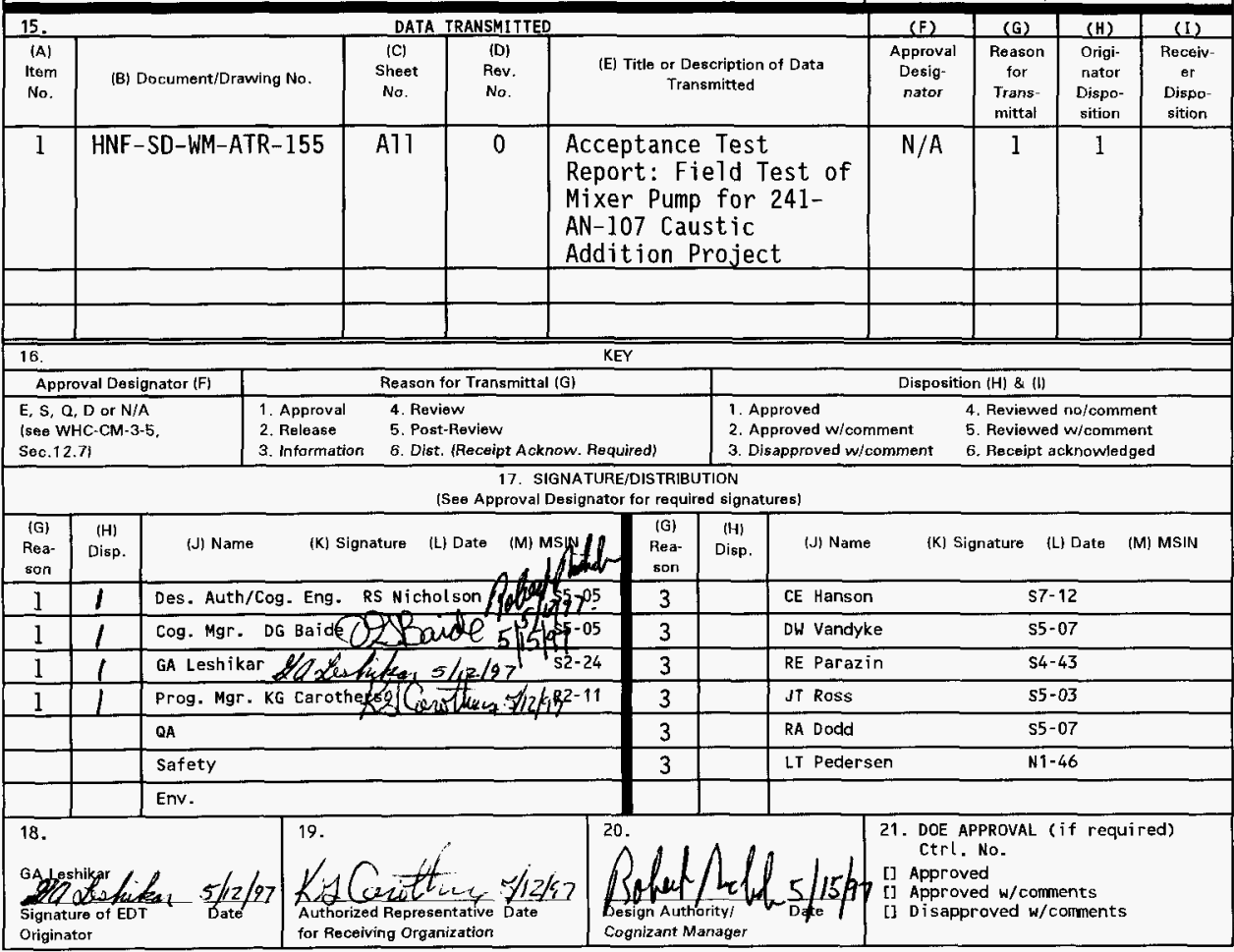




\title{
Acceptance Test Report: Field Test of Mixer Pump for 241-AN-107 Caustic Addition Project
}

\section{GA Leshikar}

SGN Eurisys Inc., Richland, WA 99352

U.S. Department of Energy Contract DE-AC06-87RL10930

\author{
EDT/ECN: EDT 612944 UC: $243 \mathrm{c}^{\circ}$ \\ Org Code: 08E00 Charge Code: N13B2 \\ B\&R Code: $E \# ; 20071$ TotaT Pages: $3<$
}

Key Words: Hazleton, mixer pump, mixing pump, caustic, caustic addition, 107-AN, 241-AN-107, AN-107, ETN-94-0010, Barrett Haentgens, submersible

Abstract: The field acceptance test of a 75 HP mixer pump (Hazleton serial \#N-20801) installed in Tank 241-AN-107 was conducted from October 1995 thru February 1996. The objectives defined in the acceptance test were successfully met, with two exceptions recorded. The acceptance test encompassed field verification of mixer pump turntable rotation set-up and operation, verification that the pump instrumentation functions within established limits, facilitation of baseline data collection from the mixer pump mounted ultrasonic instrumentation, verification of mixer pump water flush system operation and validation of a procedure for it's operation, and several brief test runs ("bump") of the mixer pump.

Photocopied information in this document are Non Coprighted materials.

TRADEMARK DISCLAIMER. Reference herein to any specific commercial product, process, or service by trade name, trademark, manufacturer, or otherwise, does not necessarily constitute or imply its endorsement, recommendation, or favoring by the United States Government or any agency thereof or its contractors or subcontractors.

Printed in the United States of America. To obtain copies of this document, contact: WHC/BCS Document Control Services, P.O. Box 1970, Mailstop H6-08, Richland WA 99352, Phone (509) 372-2420; Fax (509) 376-4989.
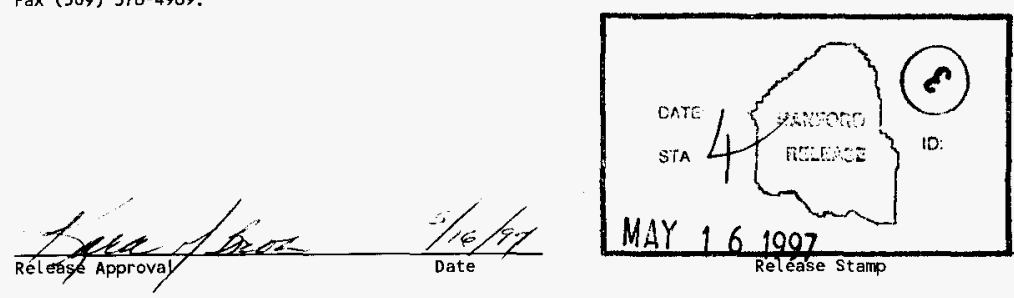

\section{Approved for Public Release}




\section{TABLE OF CONTENTS}

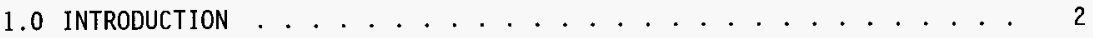

2.0 SYSTEM DESCRIPTION . . . . . . . . . . . . . . . . . 2

3.0 TEST DESCRIPTION . . . . . . . . . . . . . . . 2

4.0 TEST RESULTS . . . . . . . . . . . . . . . . 2

5.0 DISCUSSION - MIXER PUMP FIELD DATA VS. SHOP TEST DATA . . . . . 5

6.0 DISCUSSION - WATER FLUSH SYSTEM ............. 6

6.1 WATER FLUSH SYSTEM FIELD DATA ............ . . . 6

6.2 COMPARISON OF WATER FLUSH LINE ACTUAL FLOW RATE TO PREDICTED FLOW RATE ....................... 8

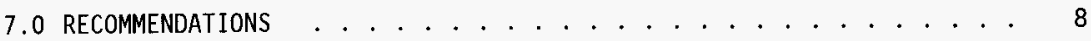

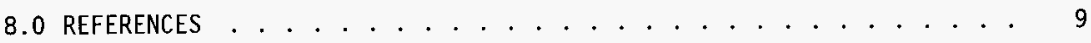

Appendix A: WHC-SD-WM-ATP-155 (signed off copy)

Appendix B: TEST EXCEPTIONS

Appendix C: TEST LOG

Appendix D: CALIBRATION DATA 
HNF-SD-WM-ATR-155

Revision 0

Page 2

\subsection{INTRODUCTION}

The field acceptance test of a $75 \mathrm{HP}$ mixer pump installation at Tank 241-AN-107 was conducted from 0ctober 1995 thru February 1996. The test was performed under JCS work package number 2E-94-00198. A copy of the workcompleted test procedure is included as Appendix A of this document. The mixer pump itself was acceptance tested previously at the 272-E shop per document WHC-SD-WM-TRP-149.

\subsection{SYSTEM DESCRIPTION}

The $75 \mathrm{HP}$ Hazleton rotating submersible mixer pump (serial no. $\mathrm{N}-20801$ ) is a key component of a caustic addition and entrainment system that has been installed at Double-She11 Tank (DST) 241-AN-107 for the purpose of increasing the hydroxide concentration of the waste. The desired result is to bring the waste into compliance with Tank Farm operating specifications for corrosion control.

The caustic addition system consists of three major components: a mixer pump, a caustic injection skid, and a pump control building. The focus of the ATP was the mixer pump installed on a stand above the central pump pit 42 " riser. The mixer pump produces $960 \mathrm{gpm}$ and 115 feet total dynamic head at $1800 \mathrm{rpm}$ and is $50^{\prime}$ long from mounting flange to bottom of discharge nozzles. Pump suction is taken approximately 68" above the tank floor and discharge is through two opposed 1.5" diameter nozzles approximately 10" above the tank floor. Discharge nozzles for caustic addition are located adjacent to the mixer pump discharge nozzles. The pump is capable of rotating thru $180^{\circ}$ to obtain $360^{\circ}$ coverage. The outside of the pump column has piping to transport caustic and flush water along with four echo ranging ultrasonic transducers and a densitometer to measure mixing effectiveness.

A portable mixer pump control building contains all the necessary electrical, control, and instrumentation hardware to operate the mixer pump. The control building, 241-AN-274, is located outside AN Tank Farm.

\subsection{TEST DESCRIPTION}

The acceptance test encompassed field verification of mixer pump turntable rotation set-up and operation, verification that the pump instrumentation functions within limits, facilitation of baseline data collection from the mixer pump mounted ultrasonic instrumentation, verification of mixer pump water flush system operation and validation of procedural steps for it's operation, and a brief test run ("bump") of the mixer pump to verify that it operates. 
HNF-SD-WM-ATR-155

Revision 0

Page 3

\subsection{TEST RESULTS}

The objectives defined in WHC-SD-WM-ATP-155 were successfully met, with two exceptions recorded. A copy of the work-completed test procedure is included as Appendix $A$ of this document. The exceptions are presented in Appendix B.

Listed below is each objective taken from WHC-SD-WM-ATP-155 followed by test results showing how the objective was achieved.

1.3.1 To verify that the mixer pump operates. This will be confirmed by briefly running the pump.

Result: On December 5, 1995 the mixer pump operated inside Tank AN-107 for approximately 45 seconds at $400 \mathrm{rpm}$ (approx. 22\% of fu11 speed). On February 15, 1996 the mixer pump was operated five or six times at $400 \mathrm{rpm}$ for durations between 30 seconds and one minute in order to allow troubleshooting of exceptions. Motor power was recorded as 1.3 $\mathrm{kW}$ and motor current draw was 22 amps. These values are nearly identical to the results obtained during shop testing (see Section 5 for comparison). Noticable, albeit very gentle, agitation of the waste surface could be discerned viewing the in-tank camera.

Water flushes of the pump inlet screen and discharge nozzles were performed each day before the mixer pump was operated.

1.3.2 To verify that the pump strain, vibration, motor temperature, and motor cavity moisture instrumentation functions within 1 imits.

Result: Pump strain, motor temperature, and motor cavity moisture instrumentation functioned and gave reasonable output within the limits given in Appendix A of the ATP. See the MIXER PUMP "BUMP" TEST DATA SHEET for recorded values.

Pump vibration instrumentation functioned but gave wildly scattered readings that quickly exceeded the limits given in Appendix A of the ATP. See Test Exception Sheet \#l for detailed description of the problem and the resolution action.

The vibration monitor, strain transmitter, and temperature monitor were calibrated before testing (see Appendix D).

1.3.3 To perform actions, such as rotating the mixer pump, that allow Iowa State/Ames Laboratory engineers to initial test the pump column mounted echo ranging ultrasonic transducers. Also to verify those tests are complete before tank mixing is commenced.

Result: Actions to support baseline data gathering from the ultrasonic transducers were performed per Section 6.2 of the ATP and such data was obtained. Results pertaining to the content or accuracy of that data were beyond the defined scope of the ATP. 
HNF-SD-WM-ATR-155

Revision 0

Page 4

1.3.4 To set the mixer pump turntable rotation arrow to the reference angle and visually verify versus the position controller readout in the pump control building. Also, to verify that mixer pump rotation in "auto mode" stops on the border of the defined non-indexing region, whose purpose is to prevent direct jet impingement on the tank thermocouple tree at full pump speed.

Result: Section 6.1 of the ATP was completed without exception. The pump turntable was rotated so the reference arrow pointed at the $90^{\circ}$ mark on the pump adaptor flange. Then the reference angle on the position controller in 241-AN-274 was set to 90.00 degrees. The pump was rotated until position controller readout was 0 degrees. Personne? observing from above the central pump pit verified that the reference arrow pointed at the $0^{\circ}$ mark. This procedure was repeated for the $180^{\circ}$ mark. Shop calibration of the position controller scale factor proved to be accurate.

Mixer pump rotation in the "auto mode" was observed to stop as expected at the $7^{\circ}$ and $173^{\circ}$ marks and, after a short time delay, reverse rotation.

1.3.5 To verify that there are no interferences in the pump pit between the cable swing arm, junction boxes, cables, and jumpers while the mixer pump turntable is rotating.

Result: Visual verification (with the cover blocks off) that there were no pump pit interferences throughout the $180^{\circ}$ range of mixer pump turntable rotation was accomplished. The power cable needed to be re-adjusted on the swing arm to avoid interference with the water flush 1 ine jumper head.

1.3.6 To test the mixer pump water flush system using raw water from AN tank farm. Also, to validate the procedure for operating the flush system in the waste tank environment.

Result: The mixer pump water flush system was used successfully per Section 6.4 of the ATP. Section 6.4 was performed four separate times. Some major items that were verified include:

- The flush system solenoid valves (normally open type) closed successfully when energized to prevent water flow into tank.

- AN farm service water pressure ranged between 100 psig and 135 psig outside the central pump pit.

System pressure was reduced to approximately 0 when the service water supply valve was closed and all in-line flush system valves open. When the isolation valve to the vacuum breaker was subsequently opened, system pressure remained at 0 psig. Total flush system depressurization allowed the safe detachment of the temporary above-ground piping apparatus (see ATP Figure 7). 
Flow rate thru the pump inlet screen branch of the flush system was approximately $4.8 \mathrm{gpm}$. See Section 6.0 for discussion.

Flow rate thru each discharge nozzle branch of the flush system was approximately $3.2 \mathrm{gpm}$. See Section 6 for discussion.

\subsection{DISCUSSION - MIXER PUMP FIELD DATA VS. SHOP TEST DATA}

A direct comparison of some field data with shop data is possible. WHC-SD-WM-TRP-222 (Reference 3) was the only shop test to utilize the variable frequency drive (VFD).

\section{MIXER PUMP SHOP DATA ${ }^{1}$ VS. FIELD DATA² FOR OPERATION AT 400 RPM}

5N-HAZLETON TYPE "SSB/MIXING" PUMP, SERIAL NO. N-20801

\begin{tabular}{|c|c|c|c|c|c|c|c|}
\hline Test & $\begin{array}{l}\text { Motor } \\
\text { Speed } \\
(\mathrm{rpm})\end{array}$ & $\begin{array}{l}\text { Motor } \\
\text { Power } \\
\text { (kt) }\end{array}$ & $\begin{array}{l}\text { Motor } \\
\text { Current } \\
\text { (amps) }\end{array}$ & $\begin{array}{l}\text { Pump } \\
\text { Vibration } \\
\text { (in/s) }\end{array}$ & $\begin{array}{l}\text { Motor } \\
\text { Temp. } \\
\text { (OF) }\end{array}$ & $\begin{array}{l}\text { Strain } / \\
\text { Unbalance } \\
\text { Load } \\
\text { (lb) }\end{array}$ & $\begin{array}{l}\text { Motor } \\
\text { Moisture } \\
\text { (yes/no) }\end{array}$ \\
\hline $\begin{array}{c}\text { WHC-SD-WM- } \\
\text { TRP-222 } \\
\text { (shop test) }\end{array}$ & 360 & 1.6 & 22.3 & $\begin{array}{l}\text { over } \\
\text { scale }\end{array}$ & $n / a^{3}$ & -4 & NO \\
\hline $\begin{array}{c}\text { WHC-SD-WM- } \\
\text { ATR-155 } \\
\text { (field test) }\end{array}$ & 400 & 1.3 & 22.3 & $\begin{array}{l}\text { over } \\
\text { scale }\end{array}$ & 106.4 & -35 & NO \\
\hline
\end{tabular}

1. Shop test fluid was water, specific gravity $=1.0$.

2. Tank 241 -AN -107 estimated specific gravity $=1.4$.

3. Motor temperature is dependent on the environment temperature, length of time the mixer pump has operated and on the horsepower delivered.

Motor power and motor current data between shop and field are essentially identical. This is encouraging but is not a conclusive indicator of proper pump performance because of the low speed at which the pump was operated. For a motor speed of $400 \mathrm{rpm}$, the pump characteristic curve (see Figure 1) predicts a flow of approximately $180 \mathrm{gpm}$ and total head of $7 \mathrm{ft}$. Using the formula to calculate brake horsepower:

$$
b h p=\frac{\text { QxTDHXsp.gr. }}{3960 x p u m p e f f i c i e n C y}=2.0=1.5 \mathrm{~kW}
$$

where: $Q=$ flowrate $=180 \mathrm{gpm}$

$\mathrm{TDH}=$ total dynamic head $=7 \mathrm{ft}$

sp. gr. = specific gravity $=1.4$

pump efficiency $=22 \%$ from characteristic curve

The predicted power of $1.5 \mathrm{~kW}$ compares favorably with the measured value of $1.3 \mathrm{~kW}$. 
HNF-SD-WM-ATR-155

Revision 0

Page 6

Pump vibration data was faulty for both the field test and the shop test (when VFD operating). Attempts to resolve the vibration problem were unsuccessful. See Test Exception \#1, Reference 3, and Reference 4 for more information.

Pump strain (unbalanced load) shop and field data compare very favorably. The difference in the values is due to wandering of the strain base value, which was expected considering the lifting stresses the pump column experienced while moving the pump out of the shop and installing it in Tank AN-107. Strain readings have varied less than $20 \mathrm{lb}$ from the unstrained initial value in both shop tests and the ATP.

During shop testing, the mixer pump motor winding RTD consistently indicated a temperature higher than ambient when the pump was at rest. A difference of approximately 7 to $8^{\circ} \mathrm{F}$ was recorded. The motor winding RTD (Rosemount, Series 78S) was determined to be the source of inaccuracy during troubleshooting. This is documented in Reference 3 . Reference 3 recommended that the shop test temperature data be used with the waste tank temperature data to obtain an "adjusted" temperature 1ine. For this reason, AN-107 thermocouple tree temperatures were recorded in the ATP. Per the manufacturer the RTD exhibits a linear resistance vs. temperature relationship. Figure 2 is an extrapolation from two temperature readings located relatively close to each other on the low end of the graph. It illustrates the potential difference between the RTD temperature readout in 241-AN-274 and what the actual temperature of the motor windings could be. The recommendation of this observer is that $10^{\circ} \mathrm{F}$ be subtracted from all motor winding temperature readings since a difference of that magnitude was actually measured. This is a conservative interpretation. This will allow longer duration mixer pump operation at full speed than would result otherwise, without risking exceedance of the manufacturer's $240^{\circ} \mathrm{F}$ temperature limit.

\subsection{DISCUSSION - WATER FLUSH SYSTEM}

\section{I WATER FLUSH SYSTEM FIELD DATA}

Section 6.4 of the ATP was performed four times for various reasons:

Test Run \#l - 11/17/95, discovered that solenoid valves not working, later found out the wiring to the solenoid switches in 241-AN-274 was not completed. Results from Test Run \#1 are therefore for flow through a11 3 branches simultaneously.

Test Run \#2 - 11/30/95, water flush procedure validated for first time, solenoid valves operating properly.

Test Run \#3 - 12/5/95, each branch flushed immediately prior to the mixer pump "bump".

Test Run \#4 - 2/15/96, each branch flushed immediately prior to initial mixer pump "bump". It is believed that this run gave the best data for flow rates. 
HNF-SD-WM-ATR-155

Revision 0

Page 7

WATER FLUSH SYSTEM FIELD DATA

\begin{tabular}{|c|c|c|c|c|c|c|c|}
\hline $\begin{array}{c}\text { Test } \\
\text { Rum } \\
\text { (see above) }\end{array}$ & Branch & $\begin{array}{c}\text { System } \\
\text { Pressure } \\
\text { (psi) } \\
\end{array}$ & $\begin{array}{r}\text { Initial } \\
\text { Gallon } \\
\text { Reading } \\
\end{array}$ & $\begin{array}{l}\text { Final } \\
\text { Gallon, } \\
\text { Reading } \\
\end{array}$ & $\begin{array}{l}\text { Total } \\
\text { Gallons } \\
\text { Used } \\
\end{array}$ & $\begin{array}{c}\text { Elapsed } \\
\text { Time } \\
\text { (minutes) }\end{array}$ & $\begin{array}{l}\text { Estimated } \\
\text { GPM }\end{array}$ \\
\hline 1 & a11 & 95 & 511079 & 511106 & 27 & $4: 00$ & 7 \\
\hline 2 & 1 & 100 & 115.8 & 122.3 & 6.5 & $1: 00$ & 6.5 \\
\hline 2 & 2 & 101 & 122.3 & 124.7 & 2.4 & $1: 00$ & 2.4 \\
\hline 2 & 3 & 101 & 124.7 & 128.6 & 3.9 & $1: 00$ & 3.9 \\
\hline 3 & 1 & 106 & 128.6 & 135.8 & 7.2 & $1: 00$ & 7.2 \\
\hline 3 & 1 & 106 & 135.8 & 180.1 & 44.3 & $13: 33$ & 3.3 \\
\hline 3 & 2 & 108 & 180.1 & 183.4 & 3.3 & $3: 00$ & 1.1 \\
\hline 3 & 3 & 106 & 183.4 & 193.8 & 10.4 & $3: 00$ & 3.5 \\
\hline 3 & 2 & 108 & 193.8 & 201.8 & 8.0 & $5: 00$ & 1.6 \\
\hline 4 & 1 & 135 & 201.8 & 206 & 4.2 & $5: 00$ & 1.0 \\
\hline 4 & 2 & 133 & 206 & 210 & 4.0 & $5: 00$ & 0.8 \\
\hline 4 & 3 & 132 & 210 & 226 & 16.0 & $5: 00$ & 3.2 \\
\hline 4 & 1 & 130 & 226 & 250.1 & 24.1 & $5: 00$ & 4.8 \\
\hline 4 & 2 & 131 & 250.1 & 266.2 & 16.1 & $5: 00$ & 3.2 \\
\hline
\end{tabular}

1. Branch \#1- pump intet screen, WST-SOV-140G and WST-sov-141 energized.

Branch \#2 - pump discharge nozzle, WST-SOV-140G and WST-SOV-142 energized.

Branch \#3 - pump discharge nozzle, WST-SOV-141G and WST-SOV-142 energized.

2. Test \#1 flow total readings taken from AN farm service water meter

Tests \#2 - \#4 flow total readings taken from in-line flowmeter (see figure 7 of ATP).

During Test \#4, toggling the applicable solenoid valve switch on/off seemed to increase the flow rates. Speculation: Debris in the raw water gets trapped in the solenoid valve. Better raw water filtration is recommended to prevent sluggish flow.

The first flush of each test run generally resulted in the highest flow rates because a significant portion of the flush line is initially vacant of fluid. For $70^{\prime}$ of $1^{\prime \prime}$ diameter hose plus about $15^{\prime}$ of empty $2^{\prime \prime}$ pipe, a quick volume calculation gives:

$70^{\prime}(12 \mathrm{in} / \mathrm{ft}) \pi\left(1^{11^{2}}\right) / 4=660 \mathrm{in}^{3}\left(\mathrm{gal} / 231 \mathrm{in}^{3}\right)=2.9$ gallons

$1^{\prime}(12 \mathrm{in} / \mathrm{ft}) \pi\left(2^{\prime \prime 2}\right) / 4=754 \mathrm{in}^{3}\left(\mathrm{ga} 7 / 231 \mathrm{in}^{3}\right)=2.5$ gallons

So it takes approximately 5.4 gallons of fluid just to fill the piping with water. 
HNF-SD-WM-ATR-155

Revision 0

Page 8

\subsection{COMPARISON OF WATER FLUSH LINE ACTUAL FLOW RATE TO PREDICTED FLOW RATE}

A pipe flow analysis of the mixer pump water flush system was performed using the computer program HYDROFLO by Engineering Software Inc., copyright 1988-90. The user creates a detailed hydraulic system including data for fluid viscosity, specific gravity, pipe roughness, loss coefficients for fittings, pipe length and pipe diameter. Some fittings were modeled as equivalent lengths of pipe and these numbers were obtained from Cameron Hydraulic Data, pg. 3-121. The flush system inlet pressure was assumed to be $100 \mathrm{psig}$ and the outlet pressure was calculated to be approximately 20 psig (because the discharge is under approximately 30 feet of fluid of specific gravity 1.4). See Figures 3 and 4 for the detailed results from HYDROFLO.

\begin{tabular}{|c|c|c|}
\hline Branch & $\begin{array}{c}\text { Predicted Flow Rate } \\
\text { Using HYDROFL0 } \\
\text { (gpm) }\end{array}$ & $\begin{array}{c}\text { Flow Rate obtained } \\
\text { during testing } \\
\text { (gpm) }\end{array}$ \\
\hline 1 & 7 & 4.8 \\
\hline 2 & 5 & 3.2 \\
\hline 3 & 5 & 3.2 \\
\hline
\end{tabular}

The analysis predicts higher flow rates thru the flush system piping than what were obtained in the field.

\subsection{RECOMMENDATIONS}

1. Install better filtration on the AN-107 raw water supply to ensure that the water flush system solenoid valves will operate without plugging.

2. Eliminate vibration indication as relevant monitoring data since it has been proven faulty. Impact to Caustic Addition Project is the possible loss of forewarning to excessive pump vibration which could lead to premature bearing wear and equipment failure. Note that vibration indication can not prevent equipment failure. There is no impact to tank safety.

3. Subtract $10^{\circ} \mathrm{F}$ from all motor winding temperature readings based on the earlier discussion of the systematicly high temperature readings given by the RTD. This will allow longer duration mixer pump operation at full speed without exceeding the manufacturer's $240^{\circ} \mathrm{F}$ temperature limit. The motor winding temperature digital indicator (which is tied into a VFD shut-off interlock) should be reprogrammed from $240^{\circ} \mathrm{F}$ to $250^{\circ} \mathrm{F}$. 
HNF-SD-WM-ATR-155

Revision 0

Page 9

\subsection{REFERENCES}

1. WHC-SD-WM-TRP-149 Test Report for Hazleton Rotating Submersible Mixer Pump SN N-20801, 2-07-94.

2. WHC-SD-WM-ATP-155 241-AN-107 Caustic Addition Project - 75 HP Mixer Pump Field Acceptance Test, 10-25-95.

3. WHC-SD-WM-TRP-222 Test Report - Pumping System for Caustic Addition Project, 6-26-95.

4. WHC-SD-WM-ATP-144 Acceptance Test Procedure for 241-AN-274 Mixer Pump Water Flush System, 7-14-95. 
HAZLETON PUMPS, INC.

A MEMBER OF THE WARMAN DTIERNATIONAL GROUP (W HNF

HAZLETON, PA 18201-0488 Telophone: 717-45E-7711 Fax: 7 LHT-SD-WM-ATR-155

Revision 0

CHARACTERISTIC CURUE

Page 10

$5 N$ TYPE SSB PUMP e 1770 RPM
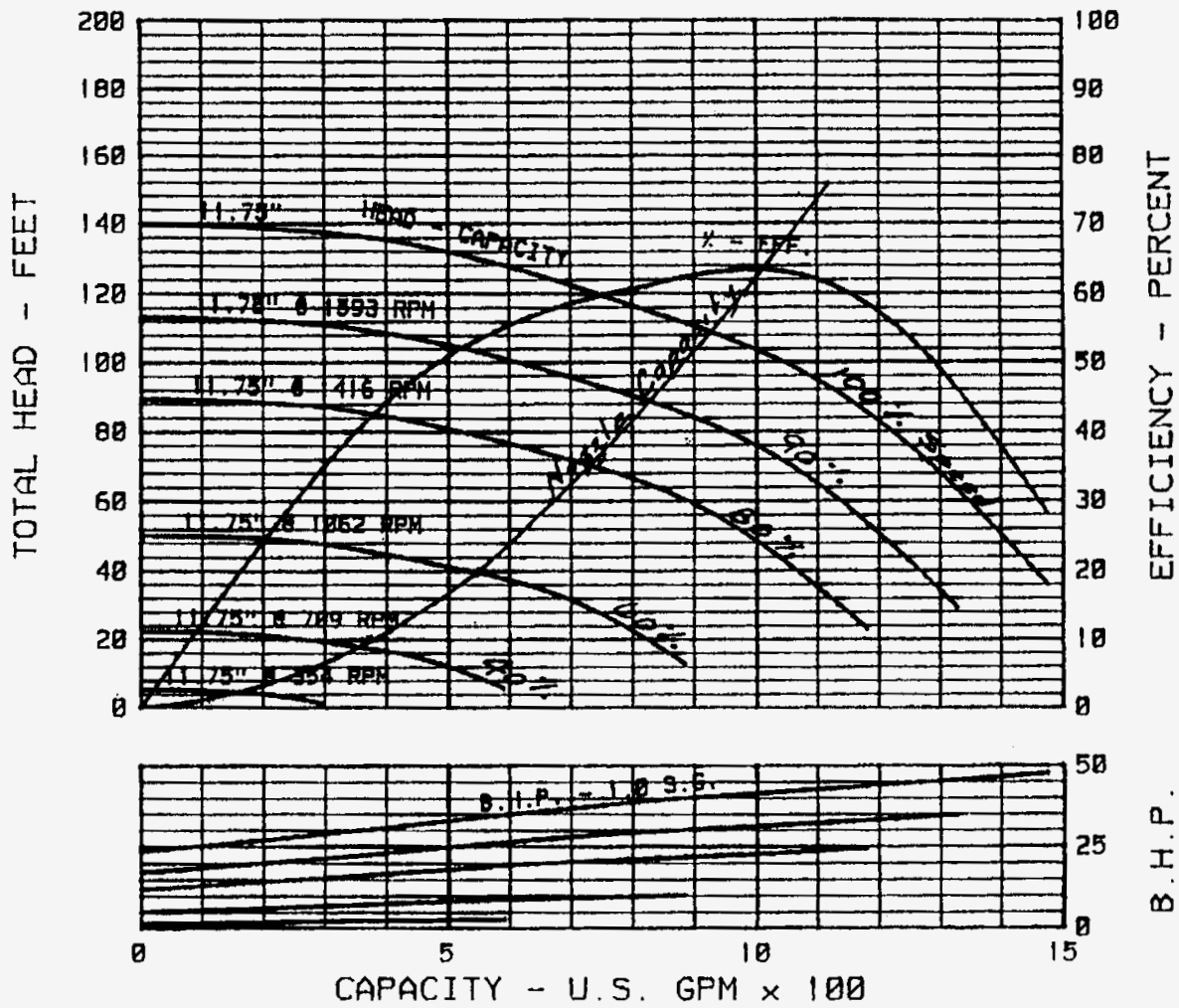

22084 Figure 1 - Mixer Pump Characteristic Curve 2/13/95 


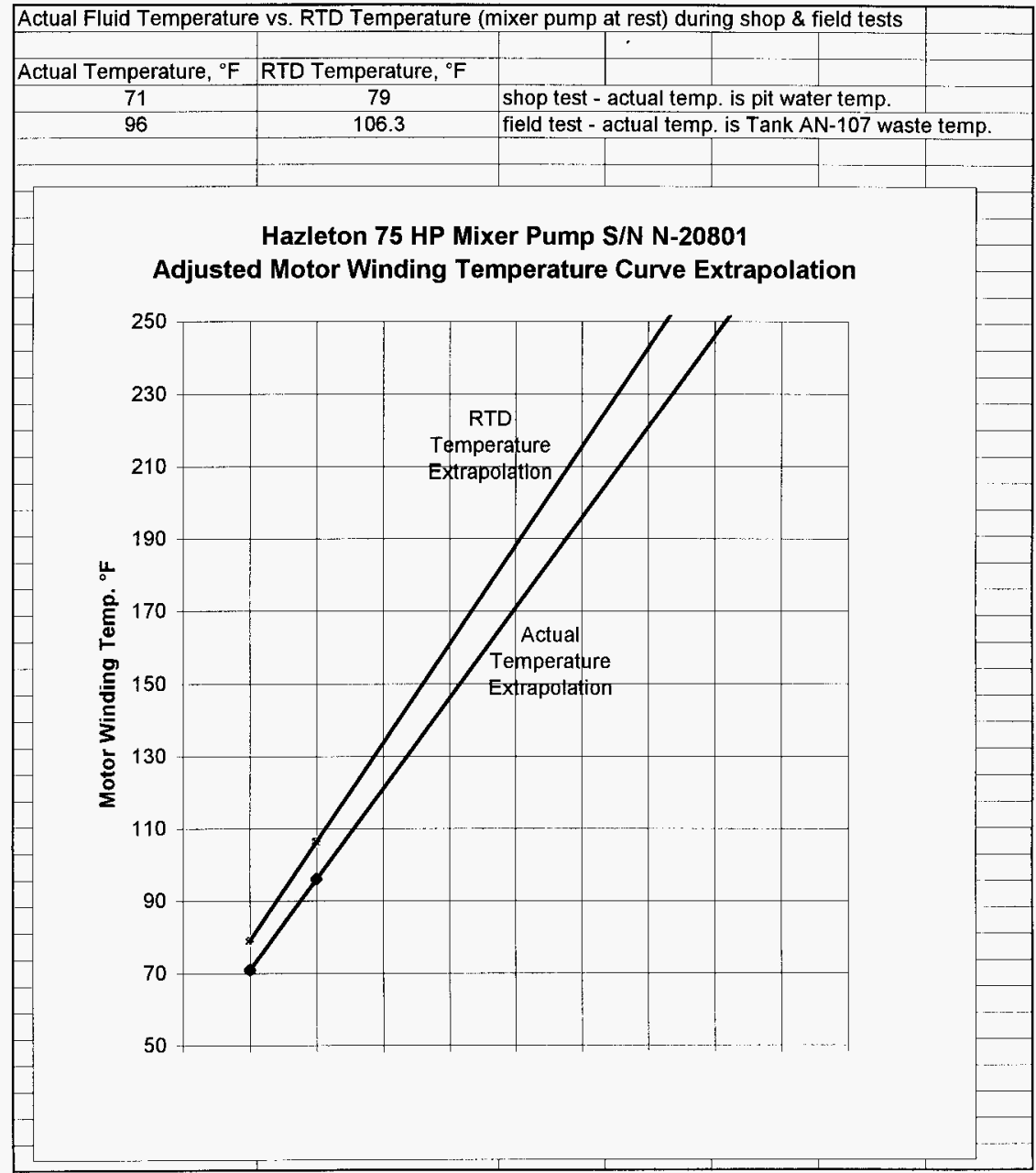

Figure 2 - Motor Winding Temperature Extrapolation 
DETAILED REPORT - INDIVIDUAL ELEMENTS

(System: SCREEN3.FLO) O flow $=7.11 \mathrm{gpm}$

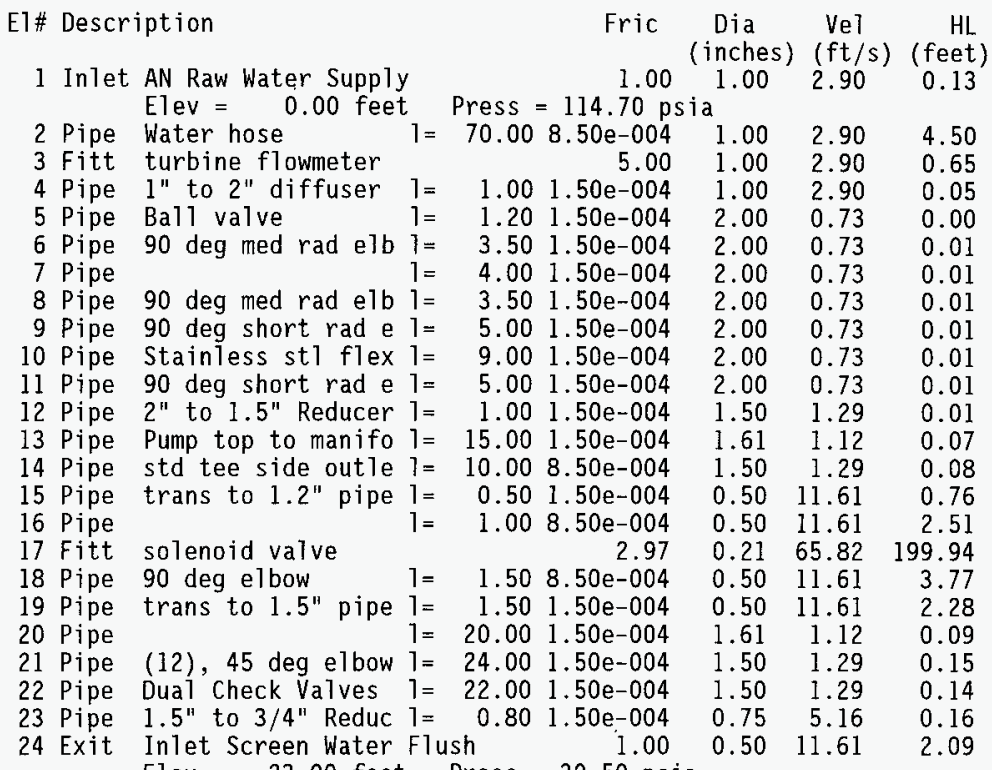

Elev $=-23.00$ feet Press $=30.50 \mathrm{psia}$

Figure 3 - Predicted Flow Rate Thru Water Flush System to Inlet Screen HYDROFLO output 
DETAILED REPORT - INDIVIDUAL ELEMENTS

(System: NOZZLE3.FLO) \& flow $=5.15 \mathrm{gpm}$

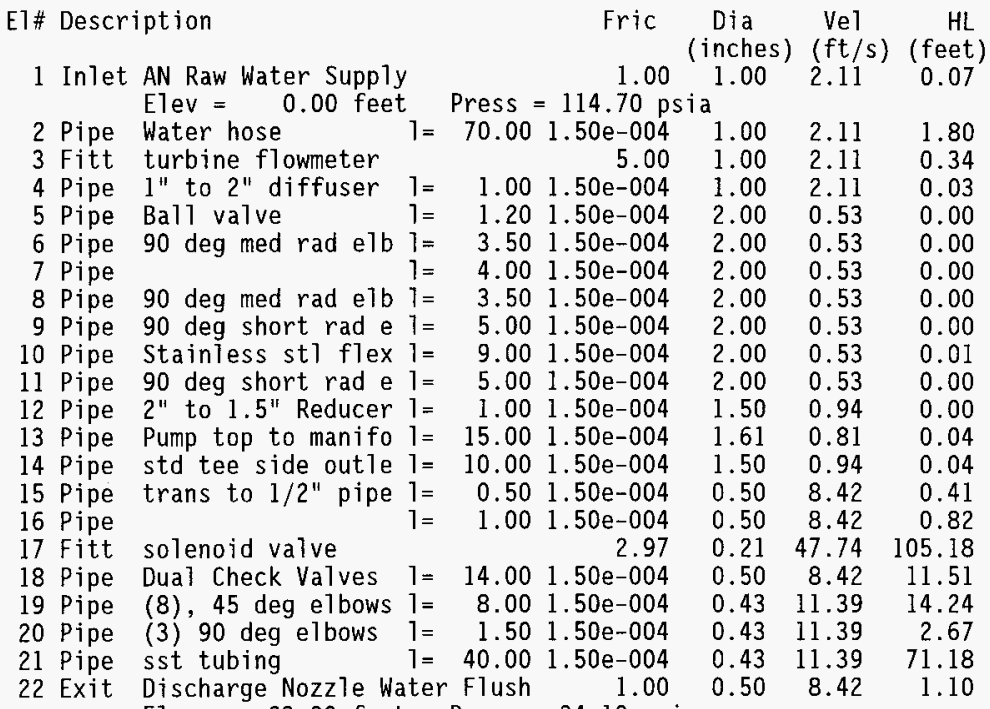

$\mathrm{Elev}=-23.00$ feet Press $=34.10 \mathrm{psia}$ 
HNF-SD-WM-ATR-155 Rev. O Page A-1 of A-43

APPENDIX A

HNF

WHAC-SD-WM-ATP-155

(signed off copy from JCS work package 2E-94-00198) 


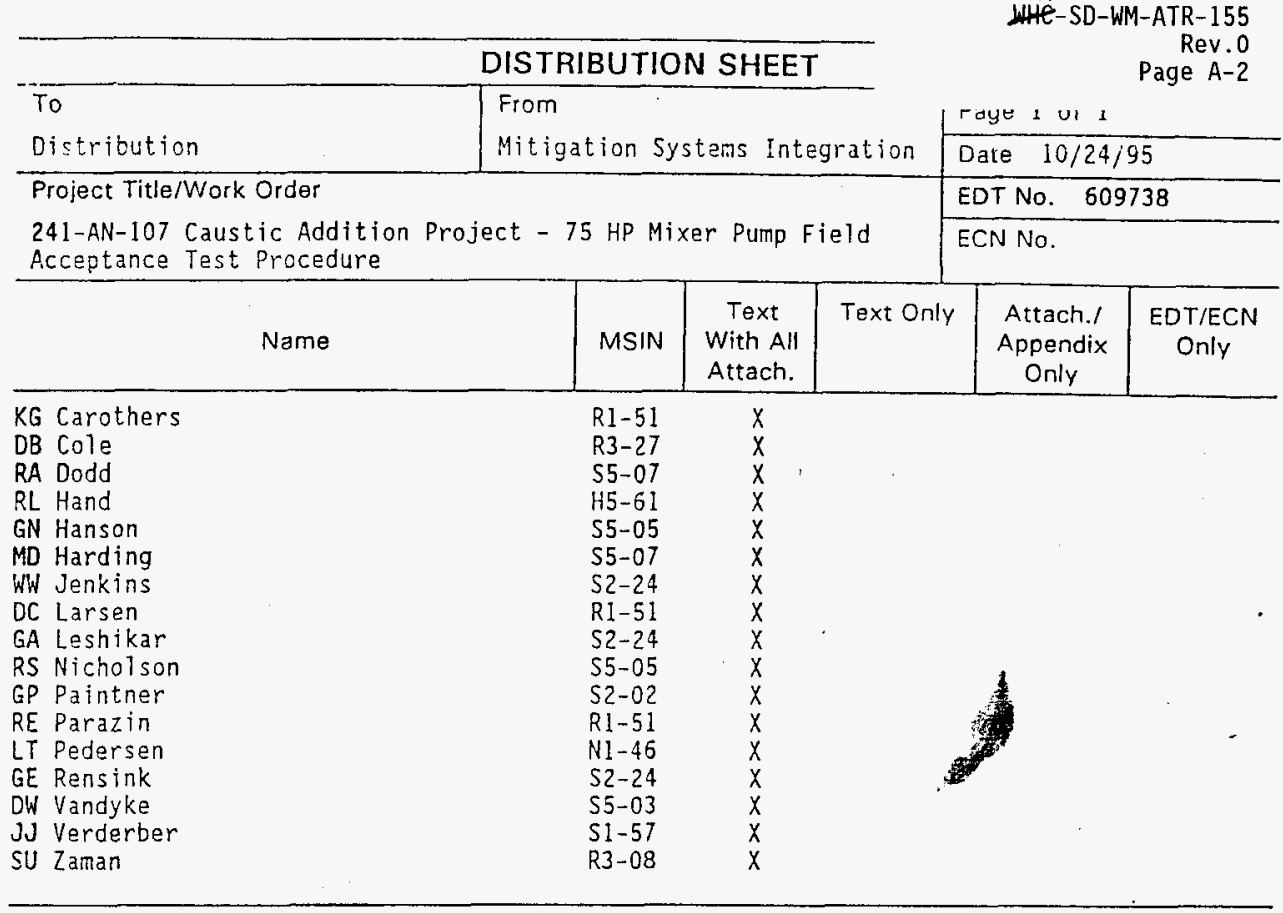

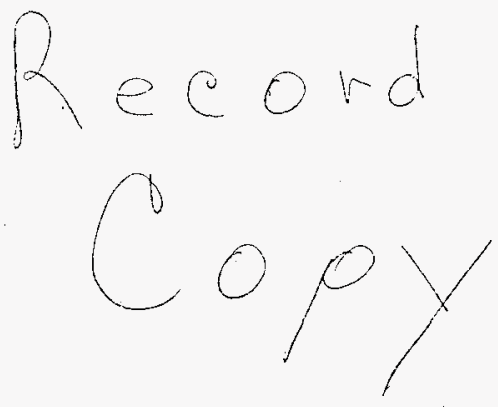

740 Rev. 9

$A-6000-135(01 / 93)$ WEFO67 
HNF

WHEC-SD-WM-ATR-155

Rev. 0

Page A-3

3. From: corigine

Process Engineering

K.G. Carothers

5. Proj./Prog./Dept./Div.:

Tank Waste Remediation

Systems

9. Originator Renarks:

ETN-94-0010

11. Receiver Remarks:
Mitigation Systems

Integration

6. Cog. Engr.:

R.S. Nicholson

Page 1 of 1 T 609738

0.

7. Purchase Order No.:

$N / A$

9. Equip./Component No.:

Hazleton S/N N-20801

10. System/Bldg./Facility: 241-AN-107

12. Major Assin. Owg. No.:

$\mathrm{H}-2-85573, \mathrm{H}-2-85264$

$\mathrm{H}-2-72010$

13. Permit/Permit Application Ma.: $\mathrm{N} / \mathrm{A}$

14. Required Response oate: October 24, 1995

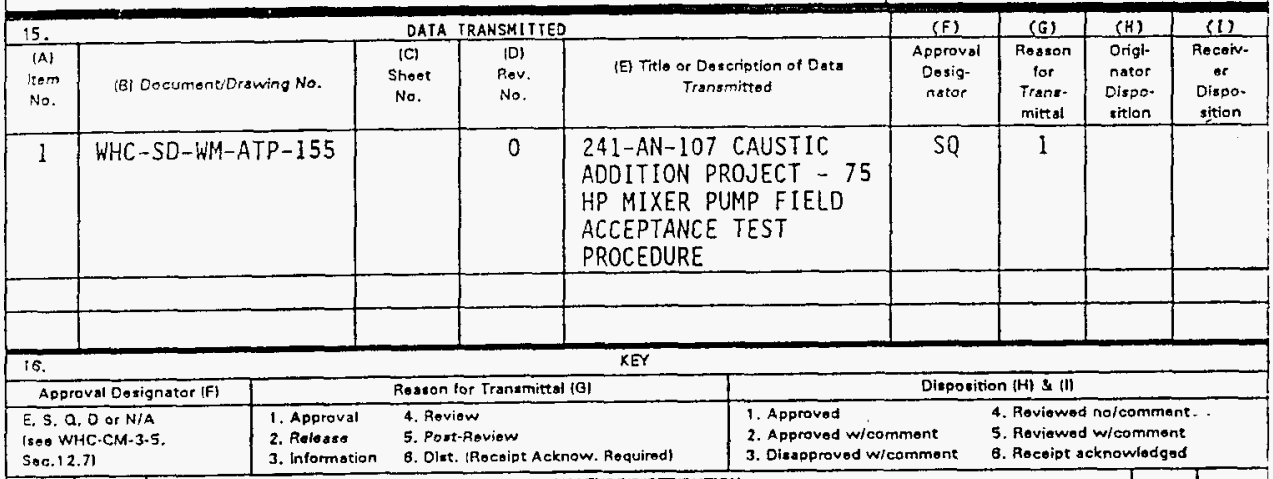

Soc.12.71 17 SIGNATUREJDIS TAIBUTION

ISoo Approval Designator for required signaturos]

\begin{tabular}{|c|c|c|c|c|c|c|c|c|c|}
\hline$|G|$ & (H) & \multicolumn{6}{|c|}{ IS ou Approval Designator for required yignatures] } & 101 & IIn \\
\hline $\begin{array}{l}\text { Roar } \\
\text { son }\end{array}$ & Dinp. & (J) Name , (K) Signature & (L) Dats (M) MSIN & (J) Name & (K) Signaturs & (t) Oats & (MI) MSIN & $\begin{array}{l}\text { Res: } \\
\text { son }\end{array}$ & Disp. \\
\hline 1 & 1 & Cog.Eng. R.S. Nicholson & $\angle 726255.05$ & M.O. Harding & & & $55-07$ & 3 & \\
\hline 1 & 1 & Cog. Mgr. G.N. H & $72-7<\leqslant 55-05$ & G.P. Paintner & & & $54-43$ & 3 & \\
\hline 1 & 1 & aA J.J. verdertyol. (Lene & $10 / 25,55-51+57$ & R.E. Parazin & & & $R 1-51$ & 3 & \\
\hline 1 & 1 & Safety Sintexanen & $=-10 / 2 v / 95 \mathrm{R} 3-08$ & G.E. Rensink & & & $52-24$ & 3 & \\
\hline & & Env. & & R.L. Hand & & & H5-61 & 3 & \\
\hline 1 & 1 & K.G. Carothers/ $\mathrm{d}(\mathrm{ces})$ & $\tan , 2 / 23=54$ & D. Larsen & & & $R 1-51$ & 3 & \\
\hline 1 & 1 & G.A. Leshikar \&. S. Lek & $\log 25 / 95^{52-24}$ & & & & & & \\
\hline
\end{tabular}

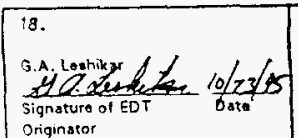

19.61

Ex Authorized Ropresentativa date for Poceiving Organization
20.

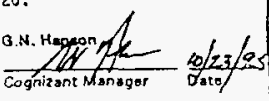

21. DOE APPROVAL (if required) cert. No.

Q) Appraved

[1 Approved $w /$ comments

[1] Disapproved $w /$ conments

उ०-7200-172-2 (04/9द) GEFOG 


\section{RELEASE AUTHORIZATION}

Document Number: $\quad W H C-S O-W M-A T P-155$, REV 0

$\begin{array}{ll}\text { Document Title: } & \text { 241-AN-107 Caustic Addition Project - } 75 \text { HP Mixer } \\ & \text { Pump Field Acceptance Test Procedure }\end{array}$

Release Date: $\quad 10 / 25 / 95$

This document was reviewed following the procedures described in WHC-CM-3-4 and is:

\section{APPROVED FOR PUBLIC RELEASE}

WHC Information Release Administration Specialist:
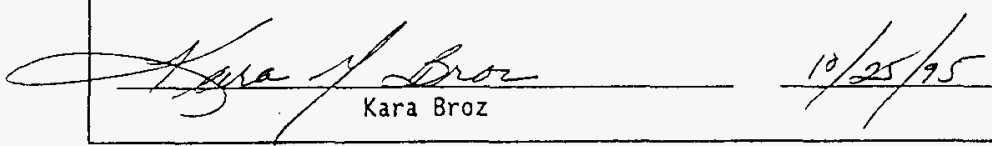

TRADEMARK DISCLAIMER. Reference here in to any specific commercial product, process, or service by trade name, trademark, manufacturer, or otherwise, does not necessarily constitute or imply its endorsement, recommendation, or favoring by the United States Government or any agency thereof or its contractors or subcontractors.

This report has been reproduced from the best available copy. Avallable in paper copy. Printed in the United States of America. To obtain coptes of this report, contact:

Westinghouse Hanford Company - Document Control Services

P.O. Box 1970, Mailstop H6-08, Richland, WA 99352

Telephone: (509) 372-2420; Fax: (509) 376-4989 
2. Title

Page A-5

241-AN-107 CAUSTIC AODITION PROJECT - 75 HP MIACN PUHP FIELD ACCEPTANCE TEST PROCEOURE

5. Key Words

Hazleton, Mixer Pump, S/N N-20801, Caustic

Addition, Tank 241-AN-107, ETN-94-0010, Barrett-

Haentjens

nIL-vu-nirar-au

0

6. Author

Hame: G.A. Leshikar

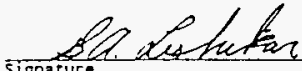

signature

Organization/Charge Code $74750 /$ E49967

\section{Abstract}

The purpose of this Acceptance Test Procedure is to briefly test run the 241-AN-107 mixer pump to ensure the mechanical, electrical and instrumentation field installations perform per design. In addition, baseline data will be collected for the mixer pump ultrasonic instrumentation before mixing is commenced.

8.

OFFICIAL RELISASE

BY WHC

DATE OCT 25.195

काa 4 . 


\section{TABLE OF CONTENTS}

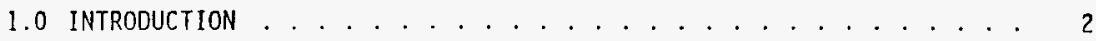

1.1 System Description ................ . . 2

1.2 scope .................... 2

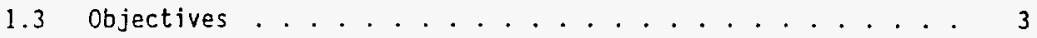

1.4 Acceptance Criteria ................... 3

1.5 Background ................. . . 3

1.6 References ................. . . . 4

2.0 RESPONSIBILITIES . . . . . . . . . . . . . . . . 6

3.0 SAFETY . . . . . . . . . . . . . . . . . 8

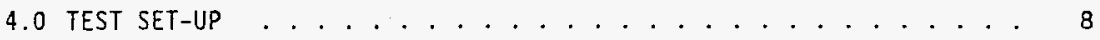

4.1 Tools, Equipment, and Supplies ........... 8

4.2 Test Instrumentation ................ . . . 16

4.3 Mixer Pump Instrumentation ............. . . 16

4.4 Special Requirements ................ . . 17

5.0 PRE-TEST CHECKS . . . . . . . . . . . . . . . . . . . . . . 18

6.0 FIELD ACCEPTANCE TESTS . . . . . . . . . . . . . 20

6.1 Mixer Pump Orientation Set-up Test ........... 20

6.2 U1trasonic Transducer Pre-Mixing Baseline Tests . . . . . . 24

6.3 Field Instrumentation Alarm Tests . . . . . . . . . . 24

6.4 Mixer Pump Water Flush System Test ... . . . . . . . . 25

6.5 Mixer Pump "Bump" Test............... 29

APPENDIX A - MIXER PUMP OPERATING CRITERIA . . . . . . . . . . 33

APPENDIX B - TEST EXCEPTION SHEET . . . . . . . . . . . . 35

APPENDIX C - TEST EXECUTION/APPROVAL SHEET . . . . . . . . . 37

\begin{tabular}{|c|c|c|}
\hline Dacuencert to. & nevert & natos nos. \\
\hline WHC-SD-WM-ATP-155 & 0 & 1: $0 F 38$ \\
\hline
\end{tabular}




\subsection{INTRODUCTION}

\subsection{SYSTEM DESCRIPTION}

A caustic addition and entrainment system has been installed at DoubleShell Tank (DST) 241-AN-107 for the purpose of increasing the hydroxide concentration of the waste. The result will be to bring the waste into compliance with Tank Farm operating specifications for corrosion control.

The system consists of three major components: a mixer pump, a caustic injection skid; and a pump control building. The focus of this ATP is the mixer pump installed in the central pump pit 42 " riser. It will be used as a platform to inject and entrain caustic with the tank waste. The mixer pump is a 50' long, 75 horsepower Hazleton rotating submersible mixer pump (S/N N-20801) with a best efficiency point of $960 \mathrm{gpm}$ a 115 feet total dynamic head. Pump suction is taken approximately seven feet above the tank floor and discharge is through two opposed 1.5" diameter nozzles approximately one foot above the tank floor.

The portable mixer pump control building contains all the necessary electrical, control, and instrumentation hardware to operate the $75 \mathrm{HP}$ mixer pump. The control building, 241-AN-274, is located outside AN tank farm.

\subsection{SCOPE}

This tast procedure provides instructions for acceptance testing of the 75 HP mixer pump instaliation at 241-AN Tank Farm. The mixer pump itself was acceptance tested previously per document WHC-SO-WM-TRP-149. The purpose of this test is to briefly test run ("bump") the mixer pump to verify that it operates, to verify that the pump instrumentation functions, to perform those tests that require an open pump pit (cover blocks off), and to facilitate the collection of baseline data by the mixer pump mounted ultrasonic instrumentation.

Testing specific to the pump control building is not required since it was recentily acceptance tested per WHC-SO-WM-ATP-135. The caustic injection skid field installation will be tested at a later date per WHC-SD-WM-OTP-190.

UTtrasonic transducer initialization testing (density monitor and echo rangers) will be performed by engineers from lowa State University / Ames Laboratory. It is not within the scope of this procedure to give detailed instructions or record data for those tests; only to perform actions that facilitate those tests and verify with lowa state that they are complete.

\begin{tabular}{|l|l|l|}
\hline$W H C-S Q-W M-A T P-155$ & 0 & 2 OF 38 \\
\hline
\end{tabular}




\subsection{OBJECTIVES}

The objectives of this test are:

1.3.1 To verify that the mixer pump operates. This will be confirmed by briefly running the pump.

1.3.2 To verify that the pump strain, vibration, motor temperature, and motor cavity moisture instrumentation functions.

1.3.3 To perform actions, such as rotating the mixer pump, that allow lowa State's engineers to initial test the pump column mounted uitrasonic transducers. Also to verify. those tests are complete before tank mixing is commenced.

1.3.4 To set the mixer pump turntable rotation arrow to the reference angle and visually verify versus the position controller readout in the pump control building. Also, to verify that mixer pump rotation in "auto mode" stops on the border of the defined nonindexing region, whose purpose is to prevent direct jet impingement on the tank thermocouple tree at full pump speed.

1.3.5 To verify that there are no interferences in the pump pit between the cable swing arm, junction boxes, cables, and jumpers while the mixer pump turntable is rotating.

1.3.6 To test the mixer pump water flush system using raw water from AN tank farm. Also, to validate the procedure for operating the flush system in the waste tank environment.

\subsection{ACCEPTANCE CRITERIA}

The "acceptance criteria" for this test are primarily verifications. If the OBJECTIVES delineated in the above section can be successfully verified, the test is a success.

\subsection{BACXGROUND}

The 75 HP Hazleton pump was purchased in 1987 as a mixer pump for the AY/AZ tank farm and was stored at 2101-M laydown yard before shop modifications to the pump were undertaken beginning in July 1993. A run-in test of the mixer pump was performed in August 1993 to ensure satisfactory performance in view of the lengthy storage period and the modifications made to the pump. For more information see documents WHC-SD-WM-TP-178, Run-In Test for Hazleton Rotating Submersible Mixer Pump S/N N-20801, and WHC-SO-WM-TRP149. Test Report for Hazleton Rotating Submersible Mixer Pump S/N N-20801.

Integrated functional and operational tests of the caustic addition system were performed at the $272 E$ Rotating Equipment Shop in November 1994 (see

\begin{tabular}{|c|c|c|}
\hline Docisusent mos. & arvanen & $\operatorname{man} 6$ \\
\hline WHC-SD-WM-ATP-155 & 0 . & 3 of 38 \\
\hline
\end{tabular}


WHC-50-WM-TRP-222, Test Report - Pumping system for Caus.

\subsection{REFERENCES}

\section{6 .1 Drawings}

(Obtain ECN printout and ECN's from Document Control for complete drawing information)

- H-2-71912, Sh. I (structural - central pump pit)

- H-2-71998, Sh. 1 (piping plan - central pump pit)

- H-2-72010, Sh. I (equipment arrangement - central pump pit)

- H-2-72030, Sh. 1 (std. farm details, raw water attachment)

- H-2-72039, Sh. 1 (piping plan - Tank 107)

- $H-2-85261$, Sh. l, (mixer pump stand)

- H-2-85253, Sh. 1, (mixer pump nozzle extensions)

- H-2-85264, Sh. I, 2, \& 3 (mixer pump assembly and modifications)

- $\mathrm{H}-2-85301$, Sh. 5 \& 5 (panelboard schedule, electrical)

- $\mathrm{H}-2-85348$, Sh. 1, 2, \& 3 (caustic injection skid)

H-2-85351, Sh. 1 thru 5 (caustic injection skid electrical)

- H-2-85433, Sh. 1 (caustic delivery system general arrangement)

- H-2-85446, Sh. 1 \& 2 (caustic injection skid base frame assembly)

- H-2-85573, Sh. 1-33 (electrical, control and instrumentation building)

- H-14-020301, Sh. 1 (AN farm service water P\&ID)

Hazleton Proprietary Drawings (mixer pump assembly and details, before modification):

- E-20801, Rev. 2, "Elevation", Hazleton 5N SSB Pump/Mixer, Mode1 \#36075-1800 (R), Order \#T7N-XBB-423827, 3-19-87. 3 drawings

- 174908, Rev. -, "Grease Arrangement", Hazleton 5N Type SSB Pump/Mixer, 12-21-87.

\section{$1.6 .2 \mathrm{CVI}$}

CVI 22528: Hazleton Bulletin 48,049, "Operation \& Maintenance Manual for $5 \mathrm{~N}$-Hazleton Type SSB/Mixing Pump", Barrett, Haentjens \& Co., Hazleton, PA 18201, 1/21/88.

CVI 22578: Bran \& Luebbe, Caustic Addition Pump System Operation and Maintenance Manual, January 1994.

CVI 22570: Eaton Corp., Variable Speed Orive Manual

CVI 22588: Butler Building Construction Manual

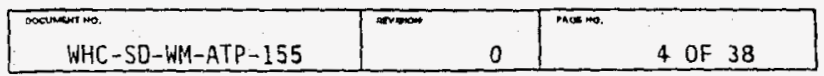




\subsubsection{WHC Controlled Documentation}

WHC-SD-WM-ATP-135 Acceptance Test Procedure for the 241-AN-274 Caustic Pump Control Building, 6-29-95.

WHC-SO-WM-ATR-135 Test Report - 241-AN-274 Caustic Pump Control Building, 9-28-95.

WHC-SD-WM-ATP-144 Acceptance Test Procedure for 241-AN-274 Mixer Pump Water Flush System, 7-14-95.

WHC-SD-WM-ATR-144 Acceptance Test Report for 241-AN-107 Mixer Pump Water Flush System. (pending release)

WHC-SD-WM-OTR-167 Test Report - Caustic Addition System Operability Test Procedure.

WHC-SD-WM-TRP-222 Test Report - Pumping System for Caustic Addition Project, 6-26-95.

WHC-SD-WM-TC-062 Test Procedure - Pumping System for Caustic Addition Project, 8-24-94.

WHC-5D-WM-TP-178 Run-in Test for Hazleton Rotating Submersible Mixer Pump SN N-20801, 8-20-93.

WHC-SO-WM-TRP-149 Test Report for Hazleton Rotating Submersible Mixer Pump SN N-20801, 2-07-94.

WHC-SD-WM-WP-208 Tank 107-AN Caustic Addition Project Mechanical Systems Engineering Work Plan - ETN-94-0010, 12-16-93.

WHC-SD-WM-ETP-021 Engineering Task Plan for 107-AN Mixer Pump Caustic Addition Project - ETN-94-0069, 12-08-93.

WHC-S-0198

Variable Frequency $A C$ Drive - Procurement Specification, 05-24-93.

WHC-S-0199

Pre-Engineered Metal Building - Procurement Specification, 05-24-93.

WHC-SD-WM-HIE-003

Safety Basis for the 241-AN-107 Mixer Pump Installation and Caustic Addition, 9-30-94.

WHC-SO-WM-DA-148 Structural Evaluation of Mixer Pump Installed in Tank 241-AN-107 for Caustic Addition Project, 5-18-95.

WHC-SD-WM-ANAL-018 Structural Evaluation of Tank 241-AN-107 Internal Components for Caustic Addition Mixing operations, 9-30-94.

\begin{tabular}{|l|l|l|l|}
\hline WHC-SD-WM-ATP-155 & & 0 & 5 OF 38 \\
\hline
\end{tabular}


WHC-SO-WM-R0-031 Tank 107AN Caustic Addition Pump Skid Requirements, 03-22-93.

T0-040-540 Raw Water Surveillance and Usage

\subsection{RESPONSIBILITIES}

2.1 Test Exceptions/Changes: Any variances from the procedure requiring more than minor red-lines, or problems encountered during testing shall be recorded on a Test Exception Sheet. The procedure step shall be referenced, the problem described, solution or caurse of action recorded, and sign-offs obtained from the Test Director, AN Farm Cognizant Engineer, and QA/QC representative; Equipment Cognizant Engineer and Safety sign-offs shall be required per AN Farm Cognizant Engineer's direction.

The following personne? will be required for the performance of this procedure:

2.2 Test Director: The Test Director has overall responsibility and authority for the performance of this test and shall ensure that the test is performed in accordance with this document. As used in this document, "Test Director" shall be understood to include Test Director designees. The Test Director shall:

- Schedule and conduct a pre-ATP meeting with the participants prior to testing.

- Notify the persons performing and witnessing the test prior to the start of testing and whenever a change is made to the testing schedule.

- Ensure the required tools and personnel are present prior to performing test activities.

- Provide direction to test operators during performance of the test.

- Witness testing and sign/date where indicated in the ATP after completion of each test step.

- Consult with cognizant engineers to determine course of action for unexpected technical problems.

- If the test procedure is suspended, determine the location in the procedure where the test will be restarted.

- Sign/date the Test Execution Sheet when execution of the ATP has been completed.

\begin{tabular}{|c|c|c|}
\hline WHC-SD-WM-ATP-155 & 0 & 6 OF 38 \\
\hline
\end{tabular}


2.3 Cognizant Facility Engineer:

- Approve red-lines to the test procedure as required. Any of the cognizant engineers may red-line items that are minor in nature such as typos, etc.

- Provide technical information during performance of test.

- Determine appropriate Approval Designators.

- Sign/Date the Test Execution Sheet when execution of the ATP has been completed.

2.4 Cognizant Pump Engineer:

- Approve mechanical equipment-related red-lines to the test procedure as required.

- Provide technical expertise during performance of test and work to resolve mechanical equipment-related test exceptions.

- Reiease the test report, ATR, upon completion of test.

\subsection{Cognizant Electrical Engineer:}

- Approve electrical equipment-related red-lines to the test procedure as required.

Provide technical expertise during performance of test and work to resolve electrical equipment-related test exceptions.

2.6 Quality: $Q A / Q C$ shall witness testing where designated, approve Test Exception resolutions, and sign/date the Test Execution Sheet when execution of the ATP has been completed and all exceptions resolved.

2.7 Safety: The responsibilities of the Safety Organization are to approve the ATP prior to field performance and approve Test Exception resolutions as necessary.

2.8 Operations: Personnel shall be provided to support testing activities.

2.9 Maintenance: Personnel shall be provided to support testing activities, including an electrician and pipe fitter.

2.10 Surveillance Systems Engineer: Responsibilities are to operate the video camera inside $A N-107$ as requested.

2.11 Industrial Hygiene: Measure AN farm primary stack $\mathrm{NH}_{3}$ concentration.

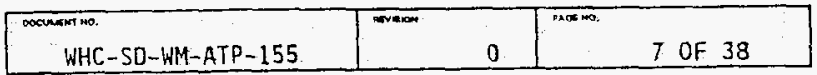




\subsection{SAFETY}

3.1 Standard WHC safety requirements and safe practices followed by tank farm operations and field personnel shall be utilized during this test and shall be in effect at all times during this test.

3.2 The Test Director has the authority to remove non-essential spectator personnel during performance of this test, if in his determination, their presence adds to the potential for injury.

3.3 For portions of this test that are performed with the cover blocks off the AN-107 central pump pit, the radiation and contamination control requirements given in mixer pump installation work plan WTYP94-009 shall be in effect.

3.4 If unexpected tank farm equipment al arms or abnormal indications are received during testing, then the test shall be immediately suspended and the equipment powered down as directed by the Test Director and Cognizant Engineers. When the reason for the unexpected condition is understood and resolved, testing activities may. be resumed after permission to do so is received from the East Tank Farms Transition Project Shift Manager.

\subsection{TEST SET-UP}

See Figures 1 thru 7 for illustrations of the site plan, mixer pump installation, pump turntable and flange, discharge nozzle water flush system, and 241-AN-274 power and instrumentation racks.

4.1 TOOLS, EQUIPMENT, AND SUPPLIES

\subsubsection{Water Flush System Hookup}

- Required equipment is specified in detail on Figure 7. Equipment includes water hose, nipples, bushings, tees, couplings, valves, pressure gauge, and flowmeter.

\subsubsection{Other Equipment}

- Two-way Radios

- Timer, watch, or stopwatch

- Digital voltmeter (480 VAC range possible)

- Clamp-on ammeter (100 A range possible)

\begin{tabular}{|c|c|c|}
\hline Dosumention. & evation & ratastat \\
\hline$W H C-5 D-4 M-A T P-155$ & 0 & 8 of 38 \\
\hline
\end{tabular}




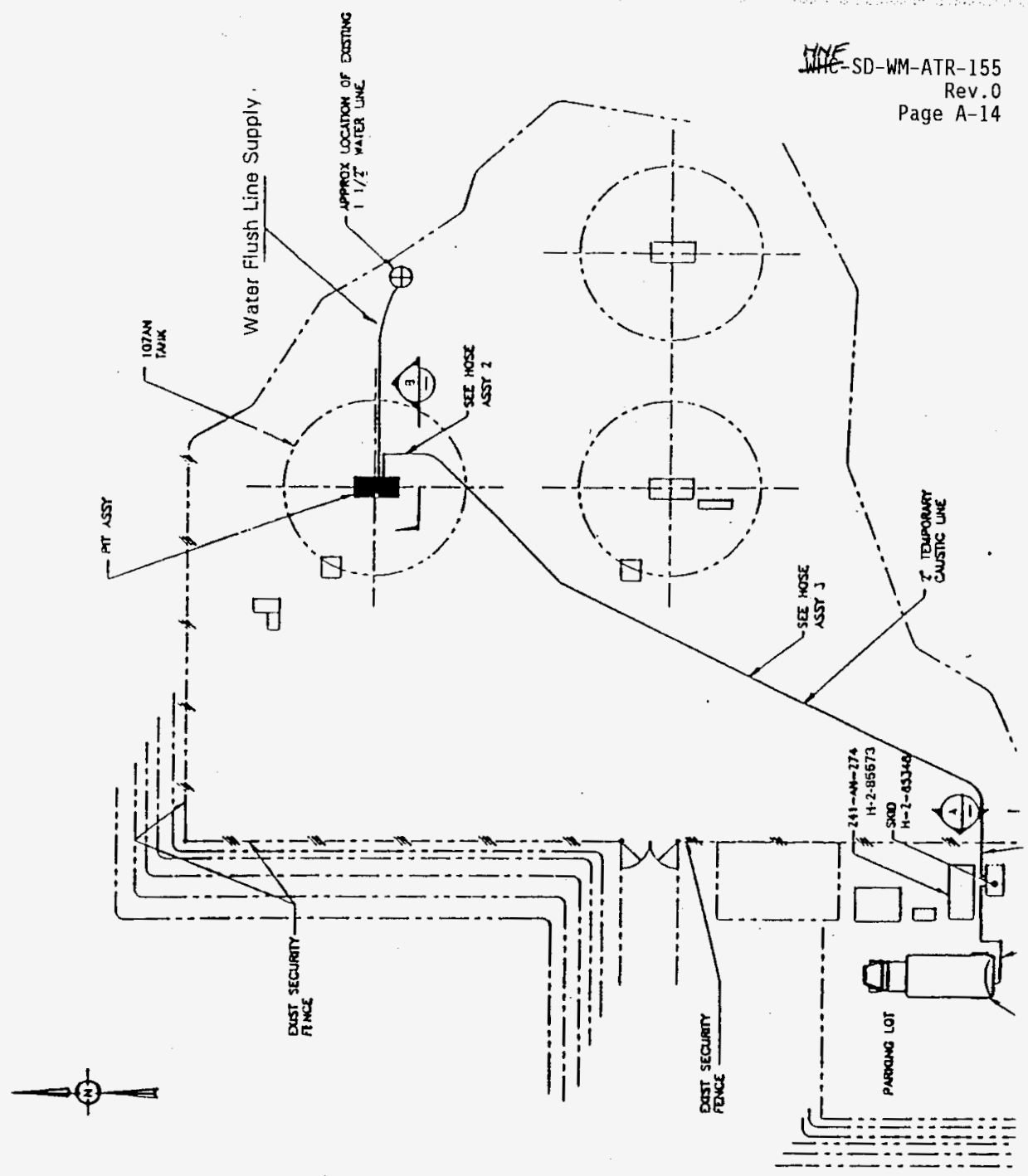

Figure 1

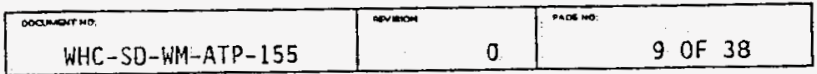




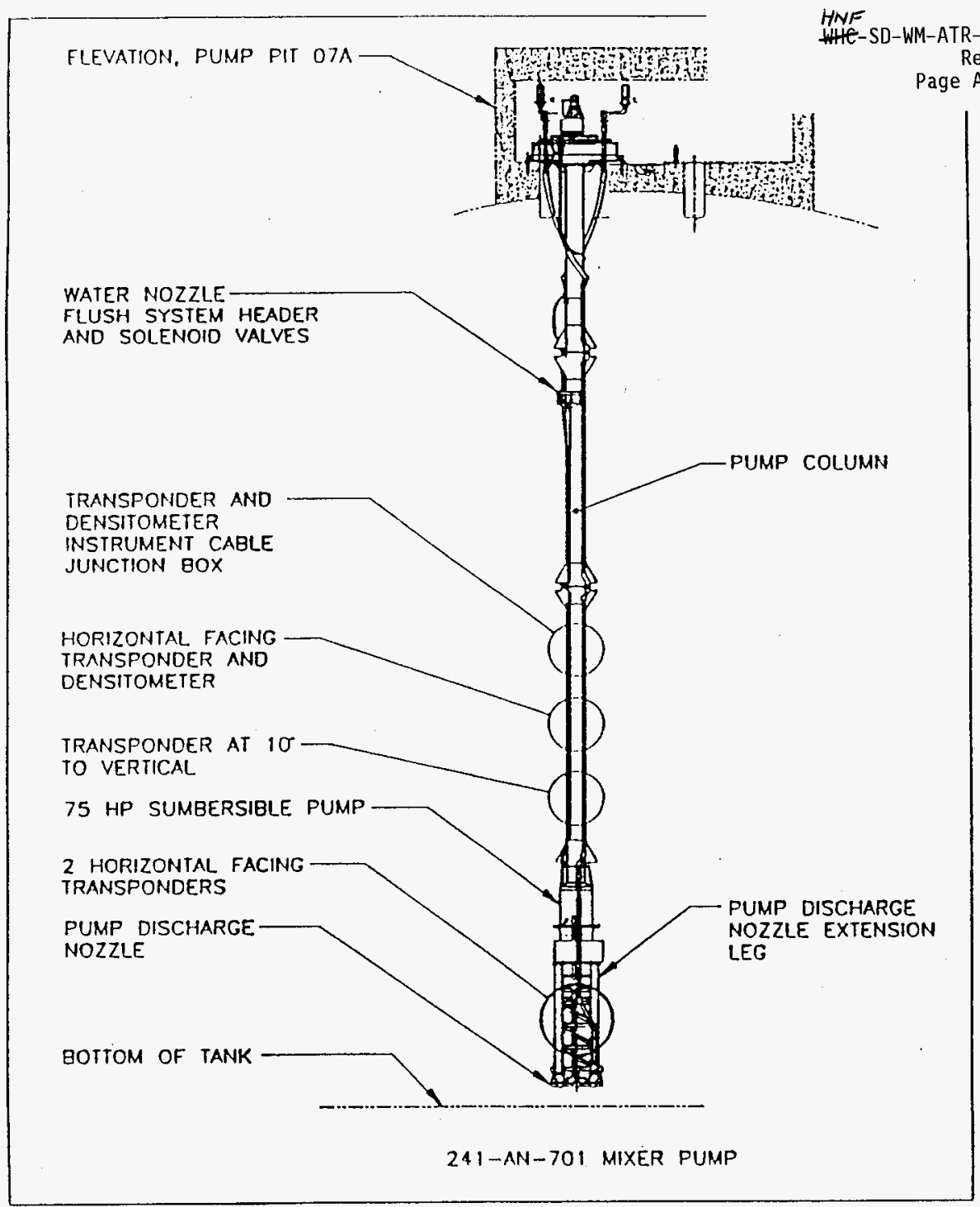

Figure 2 


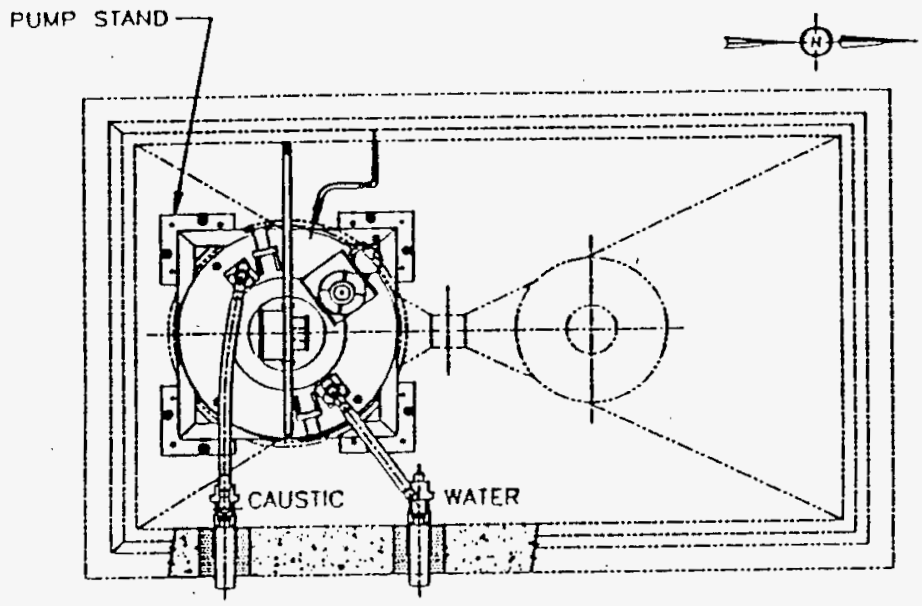

PUAN-PUMP PIT OTA

Figure 3

\begin{tabular}{|c|c|c|}
\hline Wocumasor wo. & 0 & 11 OF 38 \\
\hline
\end{tabular}




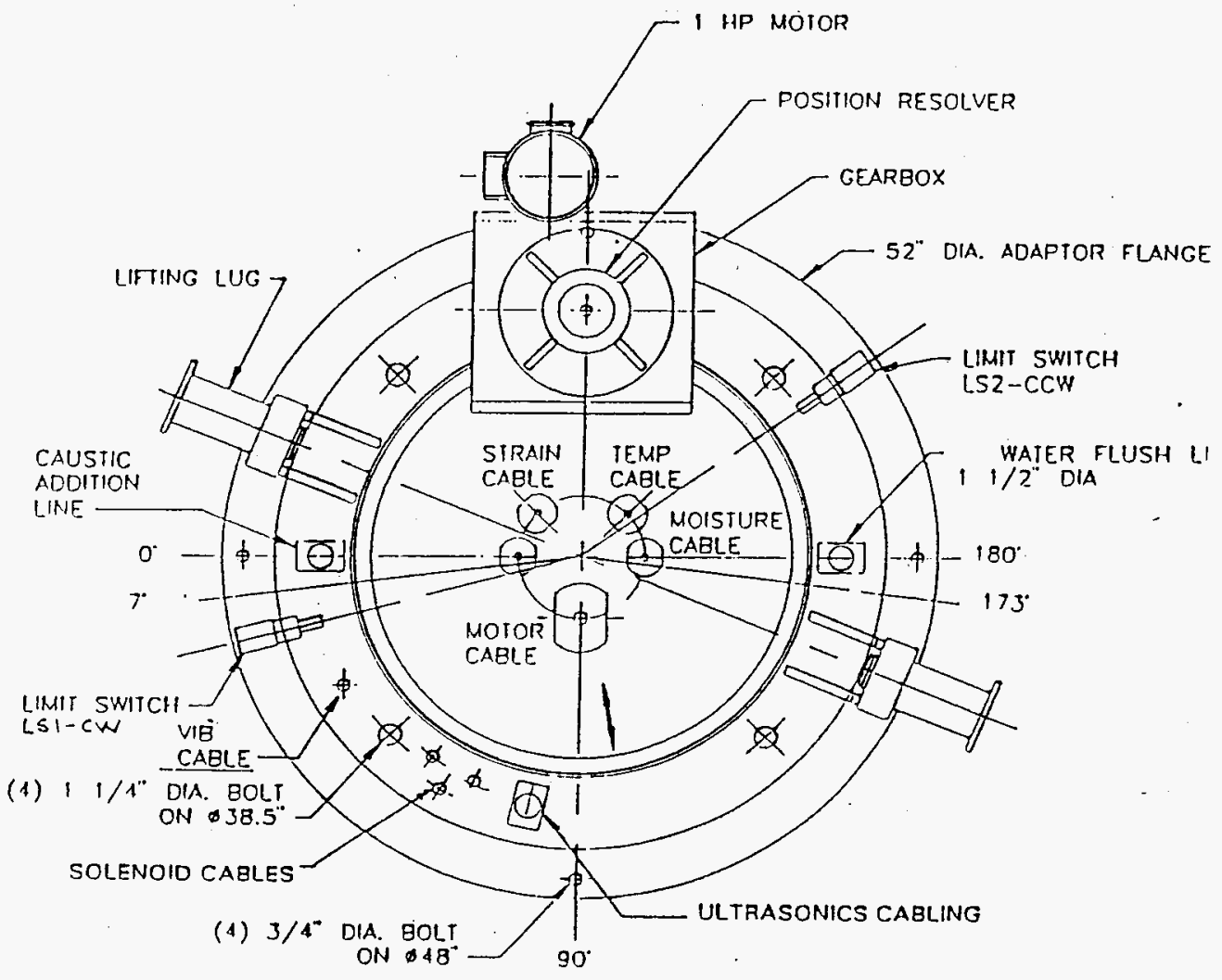

\section{MIXER PUMP TURNTABLE ASSEMBLY PLAN VIEW}

Figure 4

\begin{tabular}{|c|r|r|r|}
\hline WHC-SD-WM-ATP-155 & 0 & 12 OF 38 \\
\hline
\end{tabular}




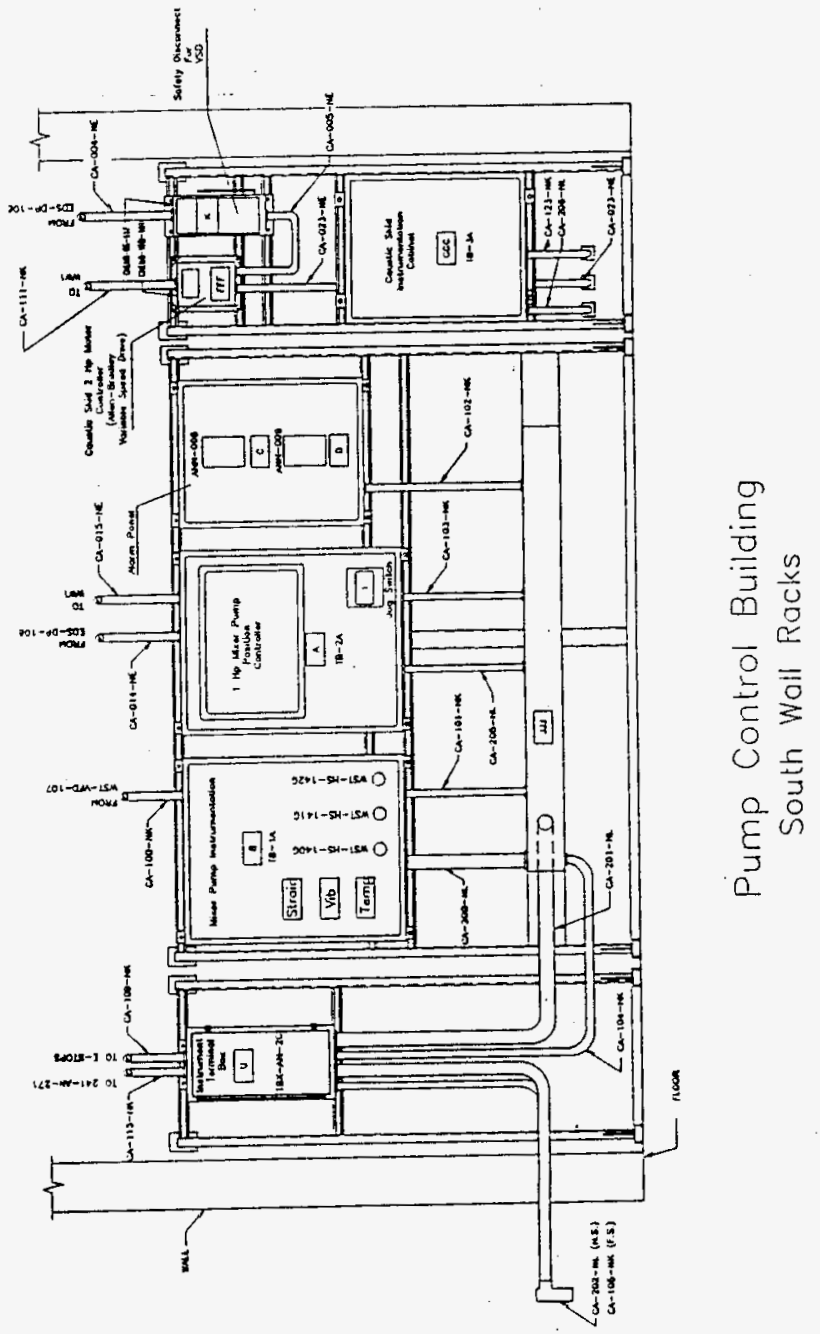

Figure 5

\begin{tabular}{|l|l|l|l|}
\hline WHC-SO-WM-ATP-155 & $\ddots$ & 0 & 13 OF 38 \\
\hline
\end{tabular}




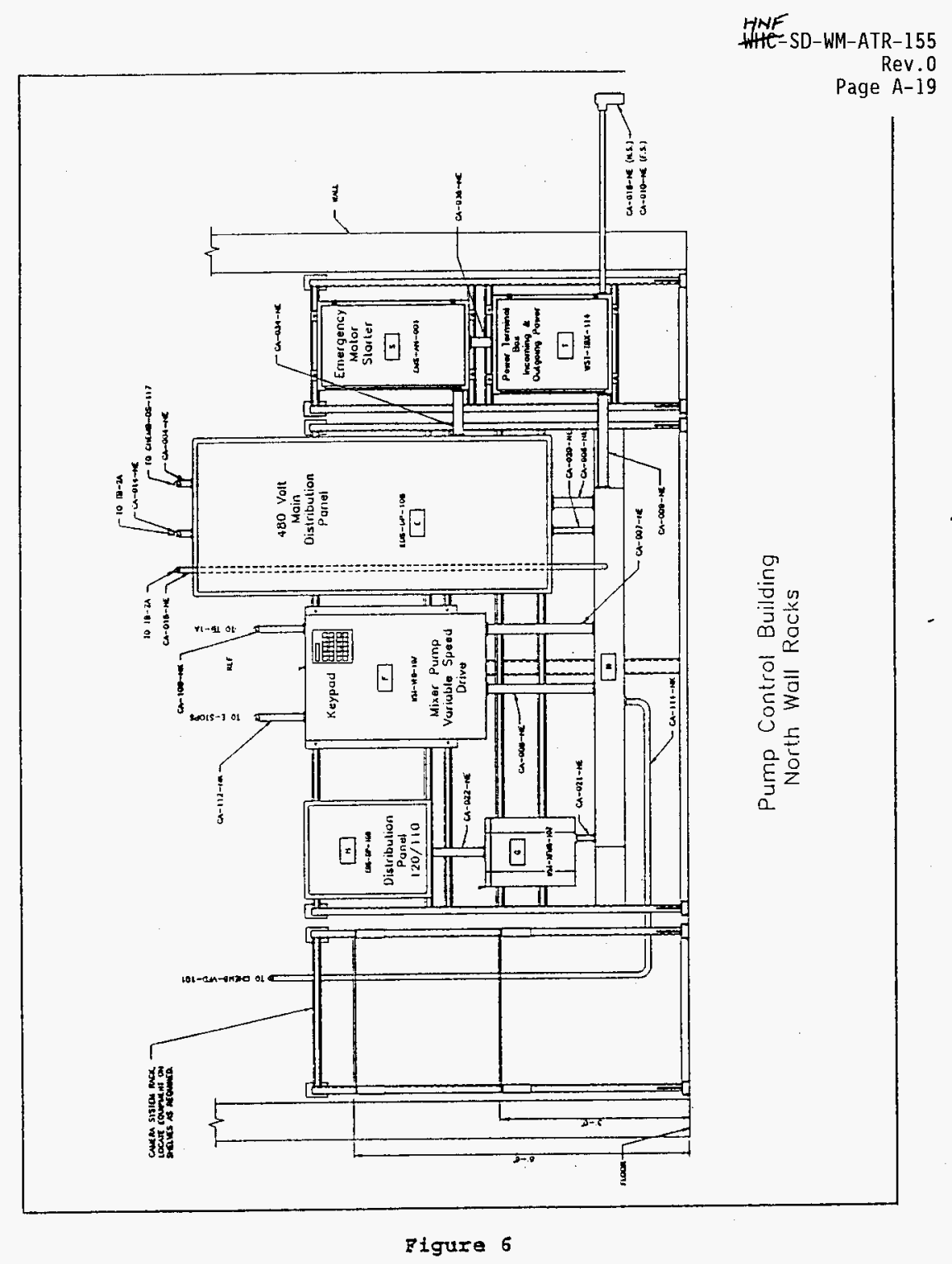

\begin{tabular}{|c|c|c|c|}
\hline WHC-SD-WM-ATP-155 & & 0 & 14 OF 38 \\
\hline
\end{tabular}




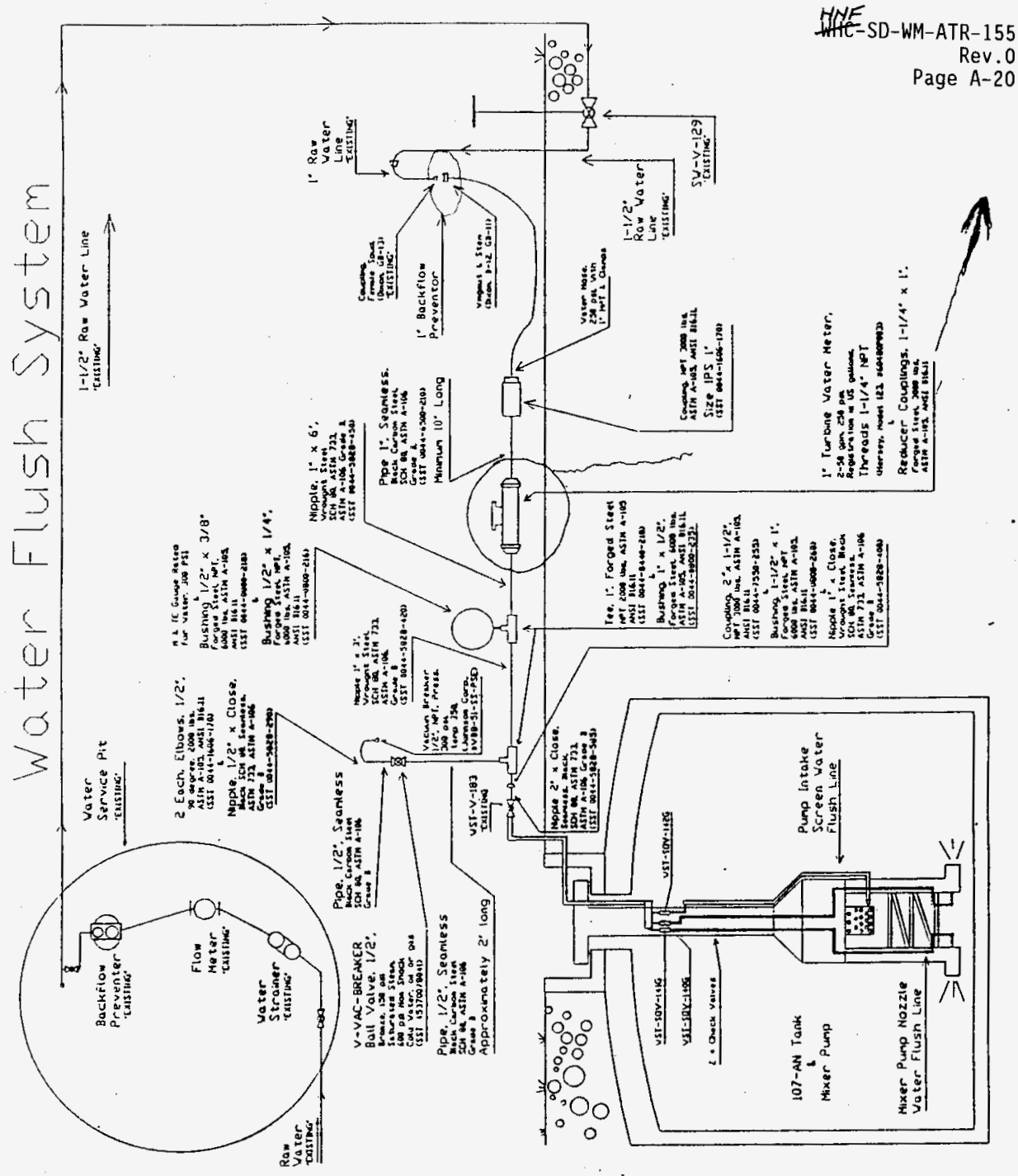

Figure 7

\begin{tabular}{|r|r|r|}
\hline$W H C-50-W M-A T P-155$ & 0 & 15 OF 38 \\
\hline
\end{tabular}




\subsection{TEST INSTRUMENTATION}

4.2.1 Test instruments shall have a valid calibration stamp attached that indicates a calibration traceable to the National Institute of Standards and Technology.

4.2.2 Test Director shall verify that the following instruments have been calibrated. Complete the following table. Note the scale of each test instrument.

\begin{tabular}{|c|c|c|c|}
\hline TEST INSTRUMENT & MAKE/MODEL & SERIAL \# & CAL. DUE \\
\hline $\begin{array}{l}\text { Voltmeter } \\
\text { (scale }\end{array}$ & $1 /$ & & \\
\hline $\begin{array}{l}\text { Ammeter } \\
\text { (scale }\end{array}$ & & & \\
\hline $\begin{array}{l}\text { Pressure gauge } \\
\text { (scale }\end{array}$ & & & \\
\hline
\end{tabular}

\subsection{MIXER PUMP INSTRUMENTATION}

Test Director

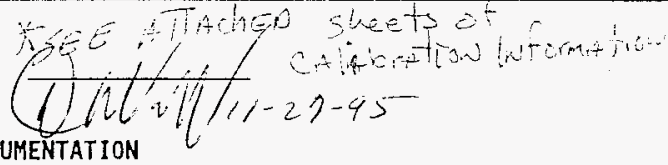

4.3.1 Test Director shall verify that the following instruments have been calibrated. Complete the following table.

\begin{tabular}{|c|c|c|c|}
\hline INSTRUMENT & MAKE/MODEL & SERIAL \# & CAL. DUE \\
\hline VMl-Vibration Monitor & $\begin{array}{l}\text { Scientific-At] anta } \\
\text { M25-41-2-15-85 }\end{array}$ & 348 & $L$ \\
\hline STl-Strain Transmitter & Acromag $161 \mathrm{~T}-\mathrm{M}$-iSG-UIC & $\times 10156$ & \\
\hline TT1-Temperature Monitor & Rosemount 444R_2U1A2NA & 27762 & \\
\hline
\end{tabular}

Test Director
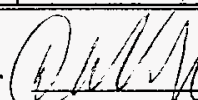

$1(-2>-45$

$$
\text { * sez l sleet }
$$

4.3.2 The load celi mounted on the mixer pump support column was zeroed at the 272-E shop (see WHC-SD-WM-TRP-222) with the mixer pump lifted vertically out of the pump pit. The base value achieved during shop testing was approximately $-5 \mathrm{lb}$ (compression). It is expected the base value will have changed slightly due to the lifting stresses the pump column has experienced while moving the pump out of the shop and into the tank.

\begin{tabular}{|c|c|c|c|}
\hline WHC-SO-WM-ATP-155 & 0 & 16 OF 38 \\
\hline
\end{tabular}




\subsection{SPECIAL REQUIREMENTS}

4.4.1 The cover blocks must be off the AN-107 central pump pit to allow visual verification of the mixer pump turntable rotation angle.

4.4.2 Raw water usage shall be per Procedure T0-040-540.

4.4.3 Interface piping (hose, fittings, gauge, etc.) must be installed between AN farm raw water supply, SW-V-129, and mixer pump water flush system inlet valve, WST-V-183, per Figure 7 .

4.4.4 Interface with WHC's engineering contact to Iowa State (Contact: Rich Hand, WHC Retrieval Engineering or designee) and with Iowa State's engineering representatives will be required during ultrasonic transducer testing. 


\subsection{PRE-TEST CHECKS}

The Test Director shall initial and date the space provided after performance of each step, unless otherwise noted.

D 0.27 ir

5.1 A pre-job ATP meeting has been conducted with the test

OV $10.27^{-45}$ participants.

$\checkmark 5.2$ VERIFY that all safety requirements, radiation and contamination

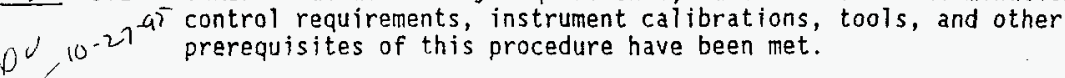

5.3
$D V 10^{-2.35}$ electrical cables in the central pump pit.

$D V$ VERIFY that labels on the mixer pump turntable and flange, and within the pump pit conform with those shown on $\mathrm{H}-2-85573$, 27 - 5 Sheets 6 and I6 (ECN 621953).

$0 v^{10-2}$ COG ENGINEER

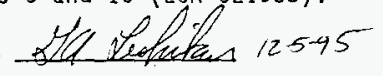

5.5 OBTAIN VERBAL CONFIRMATION that Iowa State engineers have

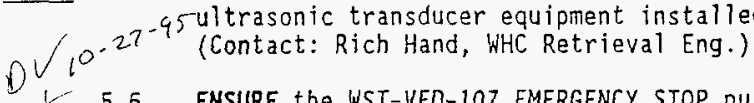

15.6 ENSURE the WST-VFO-107 EMERGENCY STOP push-pult operator on the mixer pump 75 HP VSD cabinet is pushed IN. $10 V_{10}^{5.7}-45^{\text {The following subsection is the procedure for powering up the }}$ mixer pump and the $241-$ AN-274 building electrical equipment.

5.7.1 ENSURE the WST-VFD-107 EMERGENCY STOP push-pull operator on D $19-27-45$
OUT.

5.7.2 ENSURE the WST-VFD-107 EMERGENCY STOP push-pull operator on $D^{V} / 10.27 .95$ OUT.

1) 5.7 .3 ENSURE switch WST-DS-116, 75 HP MOTOR DISCONNECT SWITCH, $11^{-27-95}$ CLOSED.

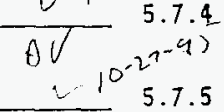

ENSURE SWitch WST-DS-115, located on the safety switch rack by pump pit 241-AN-07A is CLOSED.

ENSURE disconnect switch EDS-DS-114, located on the south exterior wall of the 241-AN-271 instrument building is CLOSED.

\begin{tabular}{|l|l|l|l|}
\hline Wocusuinto & & \\
\hline
\end{tabular}



ENSURE the following breakers in panelboard EDS-DP-108 are
CLOSED.

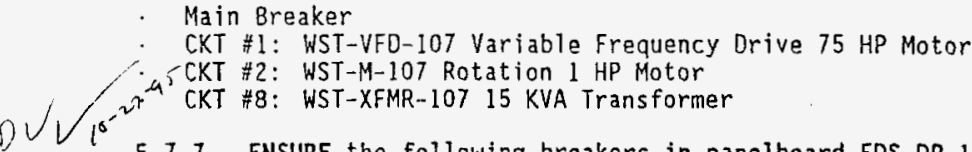

5.7.7 ENSURE the following breakers in panelboard EDS-DP-109 are CLOSED.

- Main Breaker

- CKT \#1: TB-1A Mixer Pump Instrumentation Cabinet

- CKT \#2: TB-2A 1 HP Position Controller Cabinet

- CKT \#4: ANN-008 and ANN-009 Annunciator Panels

- CKT \#6: Camera Equipment, Building 241-AN-274

- CKT \#7: Building 241-AN-274 Indoor Receptacles

- CKT \#8: Camera Equipment - Field

- CKT $\frac{49}{\pi 9}$ : Building 241-AN-274 GFI Outdoor Receptacle

- CKT \#10: Camera Equipment Rack GFI Receptacle

- CKT \#11: Building 241-AN-274 Lights

- CKT \#12: Building 241-AN-274 Heater/Air Conditioner

NOTE: S.T.O.P. stands for SoftTouch Cperator Panel. S.T.O.P. is the Eaton Corp. Variable Frequency Orive operater interface. See CVI 22570 $\frac{1}{D_{10}^{2} 5.7 .8}$

information.

PULL OUT the WST-VFD-107 EMERGENCY STOP push-pull operator on the mixer pump $75 \mathrm{HP}$ VSO cabinet.

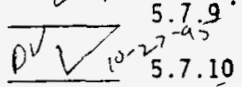
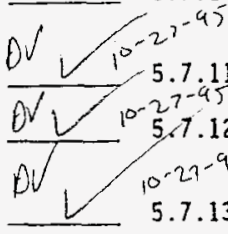

5.7 .11 $-27-45$

PRESS AND RELEASE the WST-VFD-107 5.T.O.P. OFF button.

PRESS AND RELEASE the WST-VFD-107 S.T.O.P. SPEED SET pushbutton.

PRESS AND RELEASE the WST-VFD-107 S.T.O.P. IOS pushbutton.

PRESS AND HOLD the WST-VFD-107 S.T.0.P. DOWN ARROW until

the S.T.0.P. screen indicates "S.T. 0000.00".

5.7.13 PRESS AND RELEASE the WST-VFD-107 S.T.O.P. SPEED pushbutton and verify that the S.T.O.P. screen indicates "S.P. $0000.00 "$.

\begin{tabular}{|r|r|r|}
\hline WHC-SO-WM-ATP-155 & 0 & 19 OF 38 \\
\hline
\end{tabular}




\subsection{FIELD ACCEPTANCE TESTS}

The. Test Director shall initial and date each test step as it is completed, unless otherwise noted.

\subsection{MIXER PUMP ORIENTATION SET-UP TEST}

NOTE: The cover blocks must be off the AN-107 central pump pit to allow visual verification of the mixer pump turntable rotation angle.

NOTE: Two-way radios will be required for communication between the AN107 central pump pit and the pump control building. $D V_{10}-27.95$

Visually CHECK to see that there are no obvious interferences (electrical cables or jumpers) in the pump pit that would prevent the mixer pump turntable from rotating.

in-tank video camera.

6.1.3. ENSURE electrical systems are powered up in accordance with

NOTE: The following step starts the mixer pump with an operating speed cof 0 . The pump is being "started up", but the drive shaft is not

\subsubsection{VERIFY the VFD S.T.O.P. RUN LED is illuminated.}

Note: During shop testing of the mixer pump, the vibration alarm timit could be exceeded when accelerating or decelerating the large mass of the pump with the $1 \mathrm{Hp}$ turntable motor. This is a normal occurance and no cause for concern. If the Timit programmed into the vibration digital indicator is exceeded, an interlock witl turn off the turntable (motor (and the pump) and alarm located on ANN-008 will annunciate. If $\left.(0-2)^{-9}\right)$ limits are exceeded, record on TEST EXCEPTION sheet for information E) to limit switch LS2-CCW arm. During rotation, communicate to ensure there are no electrical cable and/or jumper interferences, and view the in-tank video camera to observe for flexhose/riser interferences. Immediately stop rotation if a problem is seen.

\begin{tabular}{|c|c|c|}
\hline WHC-SD-WM-ATP-155 & 0 & 20. OF 38 \\
\hline
\end{tabular}


6.1.7 REPEAT the previous step except rotate turntable $\mathrm{cw}$, via jog switch SWL, up to limit switch LS1-CW arm.

NOTE: The following step orients the reference arrow on the pump turntable with a known point on the mixer pump adaptor flange. The arrow (black with yellow background) is on the same plane as the discharge nozzles within the tank.

$D V_{10} 6.1 .8$ SET the reference arrow on pump turntable, via jog switch SWl, to the $90^{\circ}$ mark on the pump adaptor flange.

\section{COG ENGINEER} cuitungsal by are un oyke (nat as $\left.E_{7}\right)$.

NOTE: The following step sets the reference angle on the position contraller located in 241-AN-274 to 90.00 degress.

PRESS AND RELEASE the M1890 position controller preset pushbutton. Ensure that display reads 90.00 .

NOTE: The next 2 steps set the 1 imits of turntable rotation during automatic operation. Operating limits of rotation are $7^{\circ}$ and $173^{\circ}$ (which correspond to 7.00 and 173.00 on the display).

\section{$0 V_{10}+2^{2-43} 6.1 .10$}

DU $10.2 ?^{95} 6.1 .11$

$D \vee 10^{2} \cdot 7^{-4} 6.1 .12$

DU 10.2995

DU $22^{6}, \frac{1}{2} 5^{13}$

DU 10 6.1 .14

$O V_{10-27-95}$

6.1 .15

D $\sqrt{\left.10^{-2},-9\right)}$

VERIFY that the Autotech Corp.
Module, RSPM, value is +007.00.

VERIFY that the Autotech Corp. $10-37-25$ rord single Preset

Module, FSPM, value is +173.00 .

$$
G \dot{P} .7-95
$$

VERIFY the Autotech Corp. Pos ition Controller Scaling

Factor whole part is 43 and fractional is 875 .

VERIFY the position controller option number is $10-27241$.

VERIFY that the Autotech Corp. Position Controller Decimal

Point position is 2 places from the right.

PRESS AND RELEASE the Position Controller Select function pushbutton until the LED next to POSITION ACTUAL is illuminated.

6.1 .16

Using jog switch SWl, ROTATE the pump turntable until the position controller angular readout is $0.00 \pm 0.20$ and stop.

VERIFY that the turntable arrow points very close to the $0^{*}$ mark. Visual verification is acceptable. If the arrow does not point at the designated mark, note this on a TEST EXCEPTION sheet.

COG ENGINEER

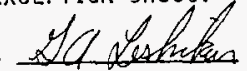

\begin{tabular}{|c|c|c|c|}
\hline WHC-SD-WM-ATP-155 & 0 & 21 of 38 \\
\hline
\end{tabular}


Note: Perform the next step only if the turntable arrow does NOT point at the $0^{\circ}$ mark. If step not performed, fill in $N / A$.

6.1.18 CALIBRATE the position controller angle measurement vs. the angle marks on the adaptor flange. Do this by trial and error, using jog switch $5 W 1$ to rotate the turntable from $0^{\circ}$ to $90^{\circ}$ or $180^{\circ}$. Adjust position controller scale factor as required. Repeat until the readout consistentiy matches the angles indicated on the flange. Record the new position controller scale factor below.

Position controller scale factor WA

$D U 1^{0.27} 6.1 .19$ Using jog switch SW1, ROTATE the pump turntable until the stop.

VERIFY that the turntable arrow points very close to the $180^{\circ}$ mark. Visual verification is acceptable. If the arrow does not point at the designated mark, note this on a TEST EXCEPTION sheet.

COG ENGINEER

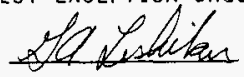

Note: Perform the next step only if the turntable arrow does NOT point at the $180^{\circ}$ mark. If step not performed, fill in $N / A$.

CALIBRATE the position controller angle measurement vs. the angle marks on the adaptor flange. Do this by trial and error, using jog switch SW1 to rotate the turntable from $180^{\circ}$ to $90^{\circ}$ or $0^{\circ}$. Adjust position controller scale factor as required. Repeat until the readout consistently matches the angles indicated on the flange. Record the new position controller scale factor below.'

Position controller scale factor $N A$

Using jog switch SW1, ROTATE the pump turntable until the position controller angular readout is approximately 90.00 .

\section{CAUTION:}

The mixer pump manual position jog switch, SWI, is not to be operated while the mixer pump is rotating under control of the

Autotech Corp. Position Controller. It is possible to instantaneously reverse the direction of the mixer pump rotation if this warning is not observed, which could cause mechanical and/or electrical failure of the pump system.

\begin{tabular}{|c|c|c|}
\hline WHC-SD-WM-ATP- 155 & Pontront. & 22 of 38 \\
\hline
\end{tabular}


Note: The following steps verify the proper operation of the TB-2A position controller automatic rotation system. Four complete cycles (reversals of the reversing motor) are required. $D V_{10-2}{ }^{-45} 6.1 .23$

DV 6.1 .24 VERIFY that the pump turntable is actually rotating D ${ }_{10} .2^{-45}$ (direction is not important).

6.1.26 Visually VERIFY that the pump turntable stops very near the $7^{\circ}$ mark or $173^{\circ}$ mark, whichever is applicable. If not, $\mathrm{D}^{\prime} \sim^{-45}$ stop test and note on a TEST EXCEPIION sheet (position
controller may need to be recalibrated).

6.1.27 VERIFY that after a few seconds delay, the turntable DU ${ }_{10} 0^{2}-95$ commences rotating in the opposite direction.

REPEAT the previous 3 steps until the automat
- $10.27-45^{-5}$ stem has traveled thru 4 complete cycles.

DU 6.1 .29 PRESS AND RELEASE TB-2A WST-M-107 STOP SW3 pushbutton and VERIFY that the pump turntable stops rotating.

Note: The following steps test the function of the rotational gvertravel imit switches, LS1-CW and LS2-CCW.

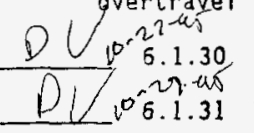

PRESS AND RELEASE TB-2A WST-M-107 START SW2 pushbutton.

While the automatic rotation system is operating, MANUALLY ACTIYATE the LS1-CW arm and VERIFY that rotation stops.

Note: The previous action should also stop mixer pump operation.

DV 10.279 ? 6.1 .32 VERIFY that VFD S.T.O.P. RUN LED is off.

1) $\sqrt{0.27-i e}$

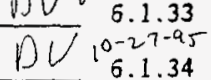

PRESS AMD RELEASE the VFD S.T.O.P. OFF pushbutton.

PRESS AND RELEASE the VFD S.T.O.P. HAND pushbutton and verify that the S.T.O.P. Screen value indicates "S.P.

DV $10.27-450000.00^{\prime \prime}$.

$0 V /{ }^{10-27}{ }^{2} .1 .35$

$0 \sqrt{10-2} 6.95$
PRESS AND RELEASE TB-2A WST-M-107 START SH2 pushbutton.

While the automatic rotation system is operating, MANUALLY ACTIVATE the LS2-CCW arm and VERIFY that rotation stops.

\begin{tabular}{|l|l|l|l|}
\hline WHC-SD-WM-ATP-155 & 0 & & 23 of 38 \\
\hline
\end{tabular}


Note: The previous action should also stop mixer pump operation.

DV $10-2.795$

6.1.38 VERIFY that VFD S.T.O.P. RUN LED is off.

\subsection{ULTRASONIC TRANSDUCER PRE-MIXING BASELINE TESTS}

NOTE: ISU - Iowa State University

DV $\begin{gathered}10-2.7-95 \\ 6.2 .1\end{gathered}$ CONDUCT a brief pre-job meeting with cognizant ultrasonic transducer equipment personnel (WHC contact to ISU and/or 5 -ISU engineers) to verify specifics of WHC support.

DU $\begin{gathered}10-27-45 \\ 6.2 .2\end{gathered}$ ENSURE electrical systems are powered up in accordance with the procedure of Section 5.7 .

D $10-27-a, 5$ PRESS AND RELEASE the VFD S.T.O.P. HAND pushbutton and verify that the S.T.O.P. screen value indicates "S.P.

DV $\begin{gathered}10-27-q_{1}-000.00 " \\ 6.2 .4\end{gathered}$ As necessary, ROTATE the pump via jog switch SWl to allow ISU to acquire data. Do not rotate pump out of the $7^{\circ}$ to
$\left(0-27-9,173^{\circ}\right.$ range identified on the position controller display.
6.2 .5 PRESS ANO RELEASE the VFD S.T.O.P. OFF pushbutton after

6.2.5 PRESS AND RELEASE the VFO S.T.O.P. OFF pushbutton after test data is obtained.

\subsection{FIELD INSTRUMENTATION ALARM TESTS}

The Pit 07A Leak Detector and Tank 107-AN High Pressure interlock and alarms are tested herein.

NOTE: Access to the AN-107 central pump pit is required to allow testing of the Pit 07A Leak Detector.

$10-22-95$

6.3.1 ENSURE electrical systems are powered up in accordance with the procedure of section 5.7 .

DV $\begin{gathered}10-27-a \text { The procedure of } \\ 6.3 .2\end{gathered}$ PRES AND RELEASE the VFD S.T.O.P. HAND pushbutton and

$D V(10-27-q$ verify that the S.T.O.P. Screen indicates "S.P.

6.3.4 "SHORT OUT" the Pit 07A Leak Detector probes.

NOTE: To "short out" the leak detector, place in a bucket of water for example. Mixer pump operation should cease.

Q $10.27-9,-$

6.3.5 VERIFY that VFD S.T.O.P. RUN LED is off.

\begin{tabular}{|ll|l|l|l|l|}
\hline WHC-SO-WM-ATP-155 & & & & & \\
\hline
\end{tabular}


(1) $10^{-27-47^{\text {is }} \text { operating. }}$

6.3.7 ACKNOWLEDGE and RESET Beta Products annunciator, ANN-008.

NOTE: The AN-107 High Pressure alarm and interlock will be tested by temporartly lifting a lead in 241-AN-274 building.

$\frac{12-90}{12-400}$

6.3.8 PRESS AND RELEASE the VFD S.T.O.P. OFF pushbutton.

6.3.9 PRESS AND RELEASE the VFD S.T.0.P. HAND pushbutton and verify that the S.T.O.P. screen indicates "S.P. 0000.00".

$12.4 p \mathrm{~V}$

6.3.10 VERIFY the VFD S.T.O.P. RUN LED is illuminated.

R-4 DV

6.3.11 "LIFT" ANN-107-2 inside TBX-AN-2C terminal TB4-1 from the Tank 107-AN High Pressure alarm.

$12^{-4} \mathrm{DV}$

6.3.12 VERIFY that VFD S.T.O.P. RUN LED is off.

$1^{2-H} D V$

$r^{-4}$

$\mathrm{DV}$

6.3.13 VERIFY that ANN-008 alarm LED is flashing and audible horn is operating.

6.3.14 "RE-ATTACH" ANN-107-2 inside TBX-AN-2C terminal TB4-1 to the Tank 107-AN High Pressure alarm.

6.3.15 ACKNOWLEDGE and RESET Beta Products annunciator, ANN-008.

\subsection{MIXER PUMP HATER FLUSH SYSTEM TEST}

VERIFY that interface piping (hose, fittings, pressure gauge, flowmeter, etc.) listed in Section 4.1, TOOLS, EQUIPMENT, AND SUPPLIES, is installed between AN farm raw water supply, SW-V-129, and water flush piping inlet valve, WST-V-183. sketch.

Note: Switches WST-HS-140G, WST-HS-141G, and WST-HS-142G operate respectively valves WST-SOV-140G, WST-SOV-141G, and WST-SOV-142G.

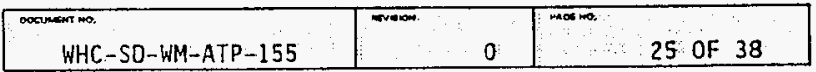


INITIAL VALVE LINEUP

\begin{tabular}{|l|l|l|l|l|l||}
\hline SW-V-129 & CLOSED & DV & WST-V-183 & OPEN & DV \\
\hline WST-SOV-140G & $\begin{array}{l}\text { ENERGIZED } \\
\text { (CLOSED) }\end{array}$ & $P V$ & WST-SOV-141G & $\begin{array}{l}\text { ENERGIZED } \\
\text { (CLOSED) }\end{array}$ & DV \\
\hline WST-SOV-142G & $\begin{array}{l}\text { ENERGIZED } \\
\text { (CLOSED) }\end{array}$ & $D V$ & V-VAC-BREAKER & CLOSED & $D V$ \\
\hline
\end{tabular}

DU $11-30-45.4 .3$ RECORD the following:

Reading on flow totalizer, FQI-AN-1, for AN farm service water (located in the 242-A Eviporator). $542^{\prime} 11 / 17 / 95$

FQI-AN-1 total $\frac{51020}{1,-97-55}$ gallons

Reading on the flowmeter/totalizer located in the water DV-12-5 -

flush system piping (see Figure 7 ).
Total gallons $11-30-95-0 V$
115,8

Note: Flush the mixer pump inlet screen first.

DV $: 1-30.9,-4.4$ DE-ENERGIZE (OPEN) WST-SOV-142G.

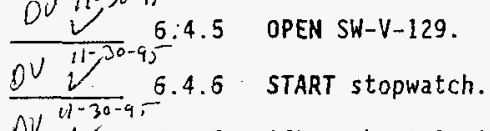

OV 6.4 After about 1 minute, RECORD system pressure from

$04-11 \cdot 30-95$ $100-11-30-95$

OV $-11-30.95$

$\stackrel{v^{\prime}}{-}$

5.4 .10 calibrated pressure gauge. Water pressure while flushing inlet screen $\frac{95<13}{12}$
After approximately 4 minutes have elapsed, ENERGIZE $\left[\begin{array}{ll}12-5-95 \\ \text { DV } 106\end{array}\right]$
(CLOSE) WST-SOV-142G.

6.4.9 STOP stopwatch. RECORD time elapsed below.

Time Elapsed - InT
RECORD the following:

至,

Reading on flow totalizer, FQI-AN-1, for AN farm service

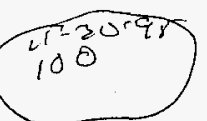

2.3

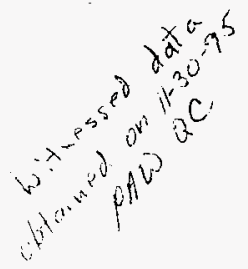

water (located in the 242-A Evaporator); Lat $1 / 17 / 95$

FQI-AN-1 total $\frac{514657}{611-17-695}$ gallons

Reading on the flowmeter/totalizer located in the water

flush system piping (see Figure 7).

\begin{tabular}{|c|c|c|}
\hline Dosentest no. & avenos & $\operatorname{san} x$ \\
\hline WHC-SD-WM-ATP-155: & 0 . & 26: OF 38 \\
\hline
\end{tabular}


RECORD pressure shown on the calibrated pressure gauge.

Service Water Pressure to Flush System

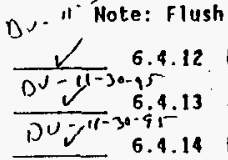
. 30.91

$D V-11-30-9,-$ $\checkmark \quad 6.4 .15$

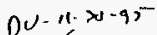
$\checkmark$ WST-5OV-141G.

$\rho^{v-11-3 a-95}$ STOP stopwatch. RECORD time elapsed below.

6.4.17 RECORD the following:

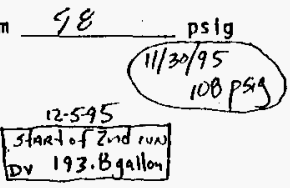

RECORD pressure shown on callbrated pressure gauge. Water pressure whlle flushing 98

DE-ENERGIZE (OPEN) WST-SOV-141G.

START stopwatch. , Stant of Ind iun
Dr 193. Bgallon

Reading on flow totalizer, FQI-AN-1, for AN farm service

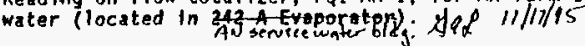

FQt-AN-1 total 511149_ gallons

Reading on the flowneter/totalizer located in the water flush system piping (see Figure 7).

Total 59 gallons

1) -11-3ote: Flush the other pump discharge nozzle. $0,11.7^{0}-95$

RECORD pressure shown on calibrated pressure gauge.

Water pressure whlle flushing psig

After 30 seconds have elapsed, ENERGIZE (CLOSE)

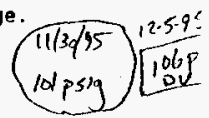
$0^{v-11-30-95}$ WST-SOV-I40G.

STOP stopwatch. RECORD time elapsed below.

TIme Elapsed - Nozzle Flush 30 5ñ

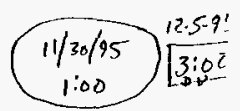

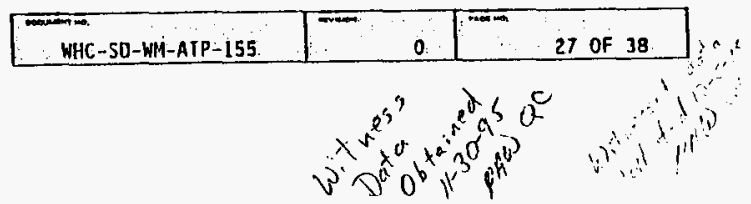


6.4.23 RECORD the following:

Reading on flow totalizer, $F Q I-A N-1$, for AN farm service water (located in Z42-A Evaporatort. sat $1 / 17 / 15$

FQ1-AN-1 total 511153 gallons

Reading on the flowmeter/totalizer located in the water flush system piping (see figure 7).

Total 59 gallons
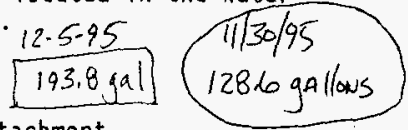

$0 \cup-11-30 t-95$ The following steps prepare for hose detachment.

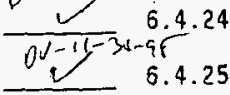

CLOSE AN farm water supply valve, SW-V-129.

DE-ENERGIZE WST-SOV-140G, WST-SOV-141G and WST-SOV-142G.

VERIFY the following valve configuration.

VALVE LINEUP AT BEGINNING OF HOSE DETACHMENT PROCEDURE

\begin{tabular}{|l|l|l|l|l|l|}
\hline SW-V-129 & CLOSED & WV & WST-V-183 & OPEN & $P V$ \\
\hline WST-SOV-140G & $\begin{array}{l}\text { DE-ENERGIZED } \\
\text { (OPEN) }\end{array}$ & DV & WST-SOV-141G & $\begin{array}{l}\text { DE-ENERGIZED } \\
\text { (OPEN) }\end{array}$ & $D V$ \\
\hline WST-SOV-142G & $\begin{array}{l}\text { DE-ENERGIZED } \\
\text { (OPEN) }\end{array}$ & DV & V-VAC-BREAKER & CLOSED & $D V$ \\
\hline
\end{tabular}

$(1-30-9)$

$D^{\sqrt{2}} v$

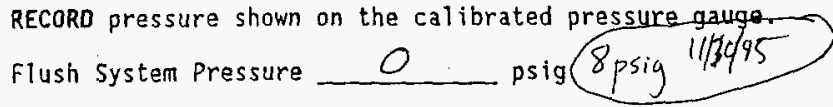

Note: The following step breaks the vacuum on the upper portion of the water flush system. Opening valve V-VAC-BREAKER, located at the piping's highest elevation, will allow air to rush in thru the vacuum breaker and relieve backpressure in the flush system, with the result $0 v-\alpha$, that water in the above-ground piping will drain into the tank. DV $=1,30-45$

6.4 .27 OPEN Valve V-VAC-BREAKER.

n) $V-1(-3,5-95$ After sufficient time for the

$\frac{v}{0 \sqrt{V} i^{1-30-9 i}}+6.4 .29$

VERIFr that the pressure shown on the calibrated pressure $12-5-95$ gauge is approximately 0 psig.

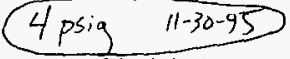
opsig

DETACH and set aside interface piping installed between raw water supply, $5 W-V-129$, and water flush inlet piping.
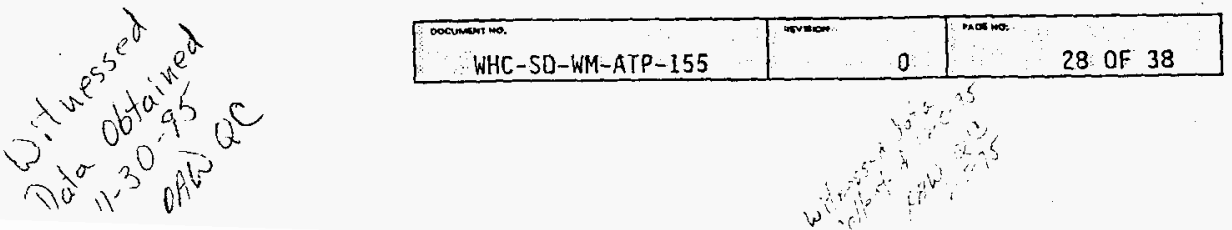


\subsection{MIXER PUMP "BUMP" TEST}

The purpose of this test is to verify that the mixer pump operates.

This will be confirmed by a brief test run of the pump.

DN $12-5-4 \sqrt{6} .5 .1$ OBTAIN VERBAL CONFIRMATION that Iowa state engineers have ultrasonic transducer equipment set-up in 241-AN-27I and have acquired their baseline data. (Contact: Rich Hand, WHC Retrieval Eng.)

DV-12-5-955.5.2 RECORD waste temperatures from selector switch WST-S5-107A, Positions 2 thru 19 (located in 241-AN-271):

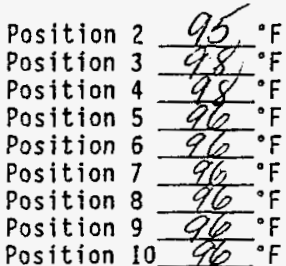

Position 10 960

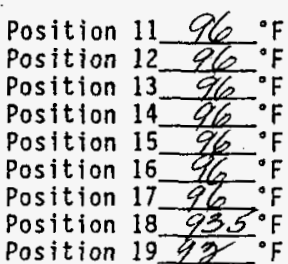

Position $1 9 \longdiv { 9 } \cdot F$

DV $(2-5-4, \overline{6} .5 .3$ RECORD baseline values for the following:

Tank AN-107 primary tank pressure -2.0

Read red pen on chart recorder. (WST-PR-107)

AN farm primary stack flowrate _.. 15 (DPI-28)

AN farm primary stack $\mathrm{NH}_{3}$ concentration 50 ppm (requires an Industrial Hygenist) O\%(EL

DU-12-5-9.5

ENSURE electrical systems are powered up in accordance with the procedure of Section 5.7 .

DU $-12-5-95-6.5 .5$ Prepare to VIEW AND RECORD the mixer pump operation with the in-tank video camera.

DU 12-5.98.5.6 PRESS AND RELEASE the VFD S.T.O.P. HAND pushbutton and verify that the S.T.O.P. screen indicates "S.P. 0000.00".

DU-12-5-95.5.7

ROTATE the turntable via jog switch SWl to approximately 90.00 as indicated on the TB-2A position controlier display.

DU.12-5- 6.5 .5

On the MIXER PUMP "BUMP" TEST DATA SHEET, RECORD baseline values for mixer pump strain, vibration, and motor temperature as shown on TB-1A. RECORD motor moisture

\begin{tabular}{|r|r|r|}
\hline WHC-SD-WH-ATP-155 & 0 & 29 OF 38 \\
\hline
\end{tabular}


indication as indicated on ANN-008. (Record 0 for motor speed, power, and current)

Note: The water flush system solenoid valves close when energized. The valves should always be shut during mixer pump operation as they provide an extra barrier against waste backflow. See Figure 7.

DV-12.5 5.5 .9 ENERGIZE (CLOSE) solenoid valves WST-SOV-140G, WST-SOV14IG, and WST-SOV-142G.

NOTE: The following steps prepare the VFD for mixer pump start with an operating speed of $400 \mathrm{rpm}$.

DV - 125-476.5.10 PRESS AND RELEASE the VFD S.T.0.P. OFF pushbutton.

PV $12-5-95.5 .11$ PRESS AND RELEASE the VFO S.T.0.P. SPEED SET pushbutton.

DV $12.5-\frac{9}{5} .5 .12$ PRESS AND RELEASE the VFD S.T.0.P. 105 pushbutton.

DV $-12-5-98.5 .13$ PRESS AND HOLD the VFO S.T.O.P. UP ARROW pushbutton until the screen indicates "S.T. 0400.00".

DU.12-5-9.5.14 PRESS AND RELEASE the VFD S.T.O.P. SPEED pushbutton and

QU-12-5-95 5.5 .15 VERIFY that all VFD S.T.O.P. LED's are off.

NOTE: This test is a "bump" and therefore of short duration (approximately 30 seconds). READ AND PREPARE FOR THE NEXT 9 STEPS BEFORE CONTINUING THE PROCEDURE.

NOTE: Operating 1 imits have been programmed into the mixer pump strain, vibration, and motor temperature digital indicators. The values are given in Appendix A. If I imits are exceeded, interlocks will shut off the pump and alarms located in ANN-008 will annunciate. If limits are exceeded, record on a TEST EXCEPTION sheet.

DU-12-5.956.5.16 START stopwatch.

DU - 12-5-926.5.17 PRESS AND RELEASE the VFO S.T.O.P. HAND pushbutton and verify that the S.T.O.P. screen value increases from "S.P. $0000.00 "$ to "S.P. 0400.00".

DU-12-5-9,6.5.18 VERIFY the VFD S.T.0.P. RUN LEO is i11uminated.

DU-12-5-9 6.5 .19 PRESS AND RELEASE the VFD S.T.0.P. M AMPS pushbutton. Record this value on the MIXER PUMP "BUMP" TEST DATA SHEET

DU-12-5-95.5.20 PRESS AND RELEASE the VFD S.T.O.P. KILOWATTS pushbutton. Record this value on the MIXER PUMP "BUMP" TEST DATA SHEET

\begin{tabular}{|c|c|c|}
\hline Docoviver mo. & SNow & $\operatorname{mos}=$ \\
\hline WHC-SD-WM-ATP-155 & 0 & 30 OF 38 \\
\hline
\end{tabular}


DV-12-3456.5.21 Record the values of mixer pump strain, vibration, and

DU $-12.5-95.5 .22$ PRESS AND RELEASE the VFD S.T.O.P. OFF pushbutton.

DU-12-5-95.5.23 VERIFY the VFD S.T.O.P. indicates "S.P. 0000.00".

DU-R.5.9.5.24 STOP stopwatch. RECORD time elapsed below.

Duration of mixer pump operation 47 sec.

DU.12-5-95.5.25 PUSH IN the WST-VFD-107 EMERGENCY STOP push-pull operator

$P v-12-5-95$ on the mixer pump $75 \mathrm{HP}$ VSO cabinet.

$\underline{D V-12-5-95} 6.5 .27$

DE-ENERGIZE solenoid valves WST-SOV-140G, WST-SOV-141G, and WST-SOV-142G.

On the MIXER PUMP "BUMP" TEST DATA SHEET, RECORD the values of mixer pump strain, vibration, and motor temperature shown on TB-1A. RECORD motor moisture indication as indicated on ANN-008. (Record 0 for motor speed, power, and current)

PV-12/5/6.5.28

RECORD values for the following:

Tank AN-107 primary tank pressure. -2.0 Read red pen on chart recorder. (WST-PR-107) y/f

Tank AN-107 peak primary tank pressure during pump bump Read red pen on chart recorder. (WST-PR-107) $=2.0$ r AN farm primary stack $\mathrm{NH}_{3}$ concentration $50 \mathrm{OPM}$ (requires an Industrial Hygenist)

DV-12-5- 5.5 .29 OPEN all breakers in EDS-DP-108 panelboard, except for:

- Main Breaker

- CKT \#8: WST-XFMR-10T 15 KVA Transformer

DV-12-5-95.5.30 OPEN all breakers in EDS-DP-109 panelboard, except for:

- Ma in Breaker

- CKT \#6: Camera Equipment, Building 241-AN-274

- CKT \#8: Camera Equipment - Field

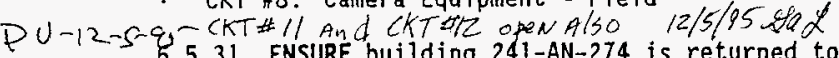

6.5.31 ENSURE building 241-AN-274 is returned to a safe and stable state before ending test.

\begin{tabular}{|l|l|l|l|}
\hline WHC-SO-WM-ATP-155 & & 0 & 31 OF 38 \\
\hline
\end{tabular}


75 HP MIXER PUMP FIELD ACCEPTANCE TE

MIXER PUMP "BUMP" TEST DATA SHEET
HUE

SD-WM-ATR-155

Rev. 0

Page A-37

5N-HAZLETON TYPE "SSB/MIXING" PUMP, SERIAL NO. N-20801

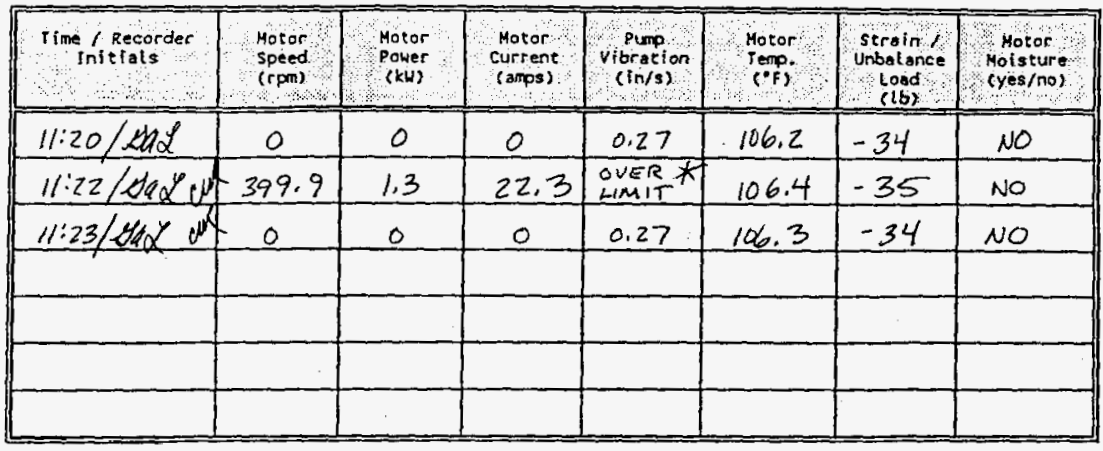

1. Tank 24l-AN-107 estimated specific gravity $=1.4$.

Data Recorders: Print name, Sign name, Date

Lishifar GA Leshikar 12-5-95

Cleanup Clkearney 12-5-95

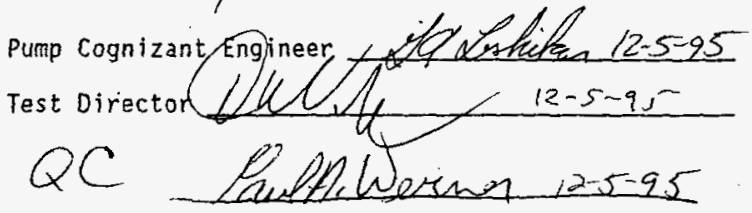

* See exception $\underset{\substack{02 \\ 12-5-95}}{ }$

$$
\begin{array}{|l|l|l|}
\hline \text { WHC-5D-WM-ATP-155 } & 0 & 32 \text { OF } 38 \\
\hline
\end{array}
$$


SWIFE SD-WM-ATR-155

Rev.0

Page A-38

\section{APPENDIX A - MIXER PUMP OPERATING CRITERIA}




\section{MIXER PUMP OPERATING CRITERIA}

Below is the expected operating range and limiting values for instrumentation when the mixer pump operates in Tank AN-107:

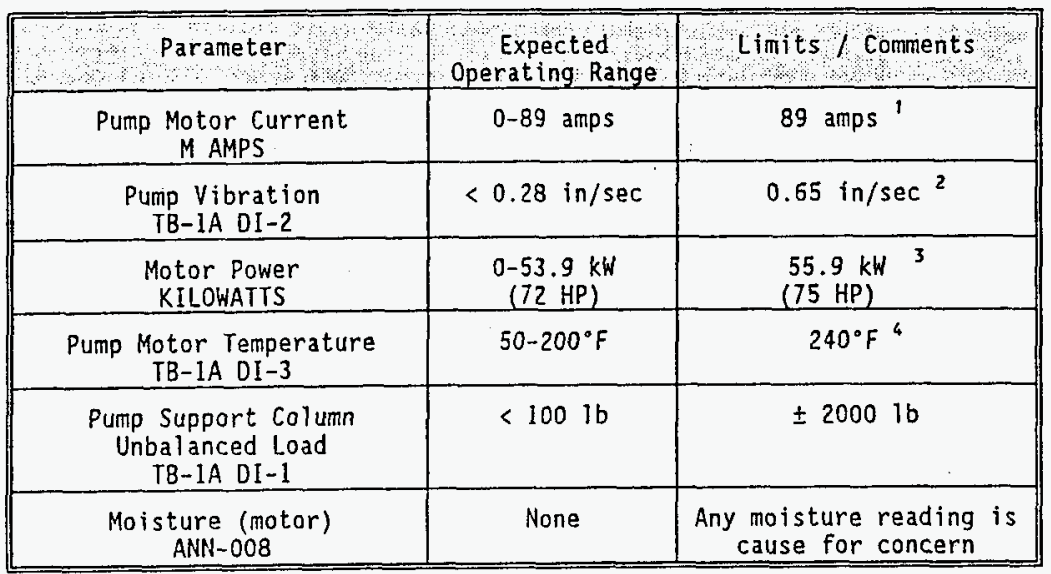

1. Full load amperage of 89 amps does not include 1.15 motor service factor.

2. Velacity value of $0.28 \mathrm{in} / \mathrm{s}$ corresponds to displacement of $3 \mathrm{mil}$. Limit value of $0.65 \mathrm{in} / \mathrm{s}$ is dictated by start/stop acceleration/deceteration of the large cantilevered pump mass by the iHP turntable rotation notor.

3. The pump was designed for fluid with specific gravity of 1.4 . If waste sp gr > 1.4, then operation at $100 \%$ speed (1800 rpm) could result in motor horsepower exceeding limit.

4. Operation at $100 \%$ speed ( 1800 rpm) could result in motor horsepower exceeding limit.
The heat load from the mixer pump co the waste will be a maximm of 3183 BTU/min. (equivalent to 75 HP).

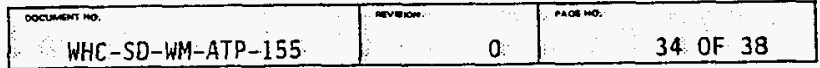




\section{APPENDIX B - TEST EXCEPTION SHEET}

(Copy as Needed) 


\section{EXCEPTION SHEET NUMBER}

Procedure Step:

Make copies of this page as necessary.

Description of Problem:

\section{SEE APPENDIX B of WHC-SD-WM-ATR-155}

Exception Resolution:

Test Director

AN Tank Farm Cognizant Engineer

$Q A / Q C$

Note: Safety and Equipment Cognizant Engineer signatures may not be required per AN Tank Farm Cognizant Engineer's direction, N/A space if not applicable.

Equipment Cognizant Engineer

Safety

\begin{tabular}{|c|c|c|}
\hline : & REvisow & 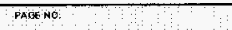 \\
\hline WHC - SO WM-ATP 155 & 0 & 36 of 38 \\
\hline
\end{tabular}




\section{TEST EXECUTION/APPROVAL SHEET}

WHC-SD-WM-ATP-155

Signature below indicates concurrence with the following:

The objectives delineated in Section 1.3 of this procedure have been achieved.

All recorded test exceptions have been resolved, the resolutions approved, and any necessary retesting completed.

Approved by:

Test Director

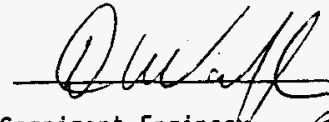

AN Tank Farm Cognizant Engineegr

AN Tank Farm Cognizant Manager

Quality Assurance

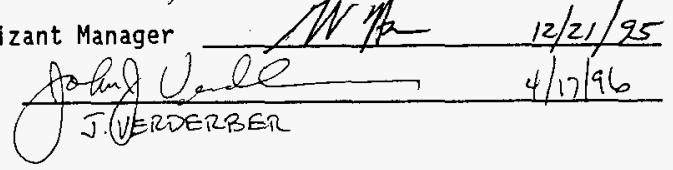

and

WHC-SO-WM-ATP-155. mon mo.

0 :


HNF
LH+CE-SD-WM-ATR-155 Rev. 0 Page B-1 of B-15

APPENDIX B

Test Exceptions 
EXCEPTION SHEET NUMBER

Procedure Step: $\quad 6.5 .21$

Make copies of this page as necessary.

Description of Problem:

Pump vibration indication exceeds limit $(0.65 \mathrm{in} / \mathrm{s})$ when the mixer pump is operated. Also, the at-rest vibration indication is approximately $0.27 \mathrm{in} / \mathrm{s}$ instead of the anticipated $0.0 \mathrm{in} / \mathrm{s}$.

Note: To facilitate troubleshooting, the lead from the vibration monitor to mixer pump interlock was lifted to prevent automatic mixer pump shutdown due to vibration overscale.

\section{Exception Resolution:}

All attempts to obtain "good" data from the vibration instrumentation failed. The resolution is to reject and not use the faulty mixer pump vibration data. The impact to the Caustic Addition Project is the possible loss of forewarning to excessive pump vibration which could lead to premature bearing wear and equipment failure. Note that vibration indication can not prevent mixer pump failure. There is no impact to tank safety.

Suspected Causes: The at-rest (mixer pump not operating) indication of 0.27 in/s is suspected to be caused by a ground 700 circuit, which can be difficult to find. Accelerometers are relatively sensitive so they may be especially prone to ground loop circuits. Electromagnetic interference from the mixer pump variable frequency drive (VFD) is suspected to play a role during pump operation. After the variable frequency drive starts the pump.

\begin{tabular}{|c|c|c|}
\hline onciunentro: & hivision & rase wo \\
\hline WHC-SD-WM-ATP- 155 & 0 & 36 of 38 \\
\hline
\end{tabular}


EXCEPTION SHEET NUMBER

Procedure Step: 6.5.21 Make copies of this page as necessary.

the vibration reading bounces around between 0.0 and $0.5 \mathrm{in} / \mathrm{s}$ before it shoots off-scale.

History: Falsely high vibration readings during VFD operation were first noted during shop testing (see WHC-SD-WM-TRP-222), where it was proven that actual pump vibration levels were the same whether run with VFD or 'across-the-7 ine' (no VFD). After extensive troubleshooting and discussions with technical experts. it was theorized that VFD-induced electromagnetic interference due to the power cable's close proximity to the vibration cable was source of the falsely high vibration readings. To attempt to solve the problem. the existing vibration cable was cut off where it exited the mixer pump rotational turntable and left in the pump column. A new vibration cabie was attached to the accelerometer (see WHC-SD-WM-ATR-144) and run entirely outside the column. Unfortunately, both time and funding constraints prevented a mixer pump run-in retest. The vibration equipment was tested for continuity and response (hit pump with hammer and verified that needle on vibration analyzer moved). however that did not conclusively proven that the problem was solved. Test Director ement. (1) oss AN Tank Farm Cognizant Engineer E.N WhGEukin

$Q A / Q C$ EM- Weger $3-4-46$

Note: Safety and Equipment Cognizant Engineer signatures may not be required per AN Tank Farm Cognizant Engineer's direction, N/A space if not applicable.

Equipment Cognizant Engineer Statestean $3 / 4 / 96$ Safety $N / A$

\begin{tabular}{|c|c|c|}
\hline Documinit Ho: & Hevision & Pacich of \\
\hline WHC-SD WM-ATP- 155 & 0 & 36 of 38 \\
\hline
\end{tabular}


EXCEPTION SHEET NUMBER 2

Procedure Step: 6.5 .21

Make copies of this page as necessary.

Description of Problem:

Operation of the mixer pump variable speed controller causes interference to the in-tank video camera image. Analys is of the camera system power supply and S-VHS signal was performed at the camera master control location. The camera power supply showed large amplitude spikes (noise) on both the neutral and ground leads, and also being radiated from the motor controller. However, temporarily changing the camera power to an independent supply produced no noticable improvement. Isolation and separation of the $A C$ supply and camera cables at the master control location also produced no noticable improvement. On the S-VHS waveform the sync puTses are clean (interference free) and the noise is in the signal components only, this indicates the interference is added prior to processing which takes place at the local control console. It now seems likely that the problem is caused by noise from the power supply to the camera system lights being inductively transferred to the video cable between the local control console and the camera.

\section{Exception Resolution:}

The image distortion is not severe. The image is acceptable for monitoring deflection of the thermocouple tree during the mixer pump OTP. This exception can be closed out for purposes of acceptance of the $75 \mathrm{hp}$ mixer pump field ATP. Resolution of this problem will take place during performance of the mixer pump OTP.

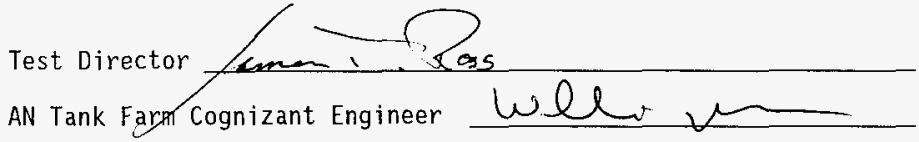

\begin{tabular}{|c|c|c|}
\hline Dociukent vo: & Mention & Pascentat \\
\hline WHC-SD-WM-ATP- 155 & 0 & 36 oF 38 \\
\hline
\end{tabular}




\section{EXCEPTION SHEET NUMBER 2}

Procedure Step: 6.5.21 Make copies of this page as necessary. E. N-whssine

QA/QC E.h-2W-egene $3-4-5 C$

Note: Safety and Equipment Cognizant Engineer signatures may not be required per AN Tank Farm Cognizant Engineer's direction, N/A space if not applicable.

Equipment Cognizant Engineer

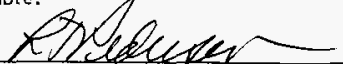

Safety N/A 


\section{$R=C O R D$ COPY}

75 HP MIXER PUMP FIELD ACCEPTANCE

\subsection{PRE-TEST CHECKS}

The Test Director shall initial and date the space provided after performance of each step, unless otherwise noted.

$\underset{2-15-96}{2.1}$ A pre-job ATP meeting has been conducted with the test

5.2 VERIFY that all safety requirements, radiation and contamination control requirements, instrument calibrations, tools, and other prerequisites of this procedure have been met.

$\mathrm{N} / \mathrm{A} \mathrm{KH} \mathrm{C}_{5.3}$ Visually VERIFY that there is no damage to any external z/LS/q6 electrical cables in the central pump pit.

$M / A K H C 5.4 \quad$ VERIFY that labels on the mixer pump turntable and flange, and $2 / 15 / 96$ within the pump pit conform with those shown on $\mathrm{H}-2-85573$, Sheets 6 and 16 (ECN 621953).

COG ENGINEER

N/A KHC5.5 OBTAIN VERBAL CONFIRMATION that Iowa state engineers have z/15/96 ultrasonic transducer equipment installed in 241-AN-271. (Contact: Rich Hand, WHC Retrieval Eng.)

af 5.6 ENSURE the WST-VFD-107 EMERGENCY STOP push-pull operator on the mixer pump 75 HP VSD cabinet is pushed IN.

5.7 The following subsection is the procedure for powering up the mixer pump and the 241-AN-274 building electrical equipment.

1.2 5.7.1 ENSURE the WST-VFD-107 EMERGENCY STOP push-pull operator on the west exterior wall of the 241-AN-274 building is pulled OUT.

$\frac{2}{2-15.96} 5.7 .2$ ENSURE the WST-VFD-107 EMERGENCY STOP push-pull operator on
the safety switch rack by pump pit 241-AN-07A is pulled
OUT. ENSURE switch WST-DS-116, 75 HP MOTOR DISCONNECT SWITCH,
$z^{-15}-9 C$ 5.7 .3 located on the safety switch rack by pump pit 241-AN-07A is CLOSED.

5.7.4 ENSURE switch WST-DS-115, 10cated on the safety switch rack 2-15-94 by pump pit 241-AN-07A is CLOSED.

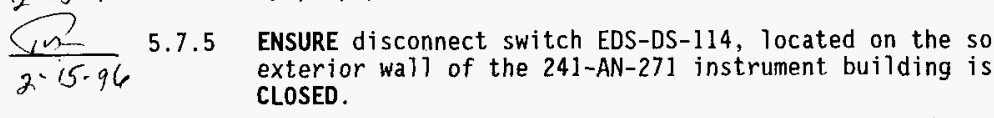

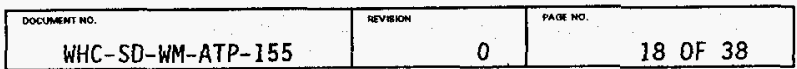


$\frac{2}{2-15 \cdot 96} 5.7 .6 \quad$ ENSURE the following breakers in panelboard EDS-DP-108 are

- Main Breaker

- CKT \#1: WST-VFD-107 Variable Frequency Drive 75 HP Motor

- CKT \#2: WST-M-107 Rotation 1 HP Motor

- CKT \#8: WST-XFMR-107 15 KVA Transformer

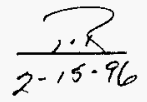

5.7.7 ENSURE the following breakers in panelboard EDS-DP-109 are CLOSED.

- Main Breaker

- CKT \#1: TB-1A Mixer Pump Instrumentation Cabinet

- CKT \#2: TB-2A 1 HP Position Controller Cabinet

- CKT \#4: ANN-008 and ANN-009 Annunciator Panels

- CKT \#6: Camera Equipment, Building 241-AN-274

- CKT \#7: Building 24I-AN-274 Indoor Receptacles

- CKT \#8: Camera Equipment - Field

- CKT \#9: Building 241-AN-274 GFI Outdoor Receptacle

- CKT \#10: Camera Equipment Rack GFI Receptacle

- CXT \#11: Building 241-AN-274 Lights

- CKT \#12: Building 241-AN-274 Heater/Air Conditioner

NOTE: S.T.O.P. stands for SoftTouch Operator Panel. S.T.0.P. is the Eaton Corp. Variable Frequency Drive operater interface. See CVI 22570 for more information.

\footnotetext{
$\frac{1, R}{2-15 \cdot 96}$

5.7.8 PULL OUT the WST-VFD-107 EMERGENCY STOP push-pu11 operator on the mixer pump 75 HP VSD cabinet.

$\frac{7.7}{2 \cdot 15 \cdot 94}$

$\frac{1 . R^{2}}{2-15 \cdot 96}$

5.7.9 PRESS AND RELEASE the WST-VFD-107 S.T.0.P. OFF button.

5.7.10 PRESS AND RELEASE the WST-VFD-107 S.T.0.P. SPEED SET pushbutton.

$\frac{\sqrt{12}}{2 \cdot 15 \cdot 96}$

$\frac{1.25}{2-5 \cdot 96}$

5.7.11 PRESS AND RELEASE the WST-VFD-107 S.T.0.P. 10S pushbutton.

5.7.12 PRESS AND HOLD the WST-VFD-107 S.T.0.P. DOWN ARROW until the S.T.O.P. screen indicates "S.T. 0000.00".

$\frac{\pi}{2-15-96}$

5.7.13 PRESS AND RELEASE the WST-VFD-107 S.T.0.P. SPEED pushbutton and verify that the S.T.O.P. screen indicates "S.P. $0000.00 "$.
}

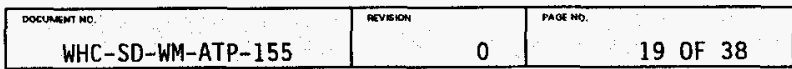




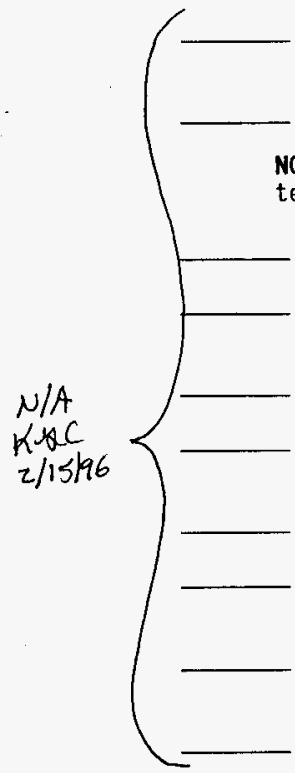

6.3.6 VERIFY that ANN-008 alarm LED is flashing and audible horn is operating.

6.3.7 ACKNOWLEDGE and RESET Beta Products annunciator, ANN-008.

NOTE: The AN-107 High Pressure alarm and interlock will be tested by temporarily lifting a lead in 241-AN-274 building.

6.3.8 PRESS AND RELEASE the VFD S.T.0.P. OFF pushbutton.

6.3.9 PRESS AND RELEASE the VFD S.T.0.P. HAND pushbutton and verify that the S.T.0.P. screen indicates "S.P. 0000.00".

6.3.10 VERIFY the VFD S.T.0.P. RUN LED is illuminated.

6.3.11 "LIFT" ANN-107-2 inside TBX-AN-2C terminal TB4-1 from the Tank 107-AN High Pressure alarm.

6.3.12 VERIFY that VFD S.T.0.P. RUN LED is off.

6.3.13 VERIFY that ANN-008 alarm LED is flashing and audible horn is operating.

6.3.14 "RE-ATTACH" ANN-107-2 inside TBX-AN-2C terminal TB4-1 to the Tank 107-AN High Pressure alarm.

6.3.15 ACKNOWLEDGE and RESET Beta Products annunciator, ANN-008.

\subsection{MIXER PUMP WATER FLUSH SYSTEM TEST}

$\frac{.12}{2-15 \cdot 96}$

6.4.1 VERIFY that interface piping (hose, fittings, pressure gauge, flowmeter, etc.) listed in Section 4.1, TOOLS, EQUIPMENT, AND SUPPLIES, is installed between'AN farm raw water supply, SW-V-129, and water flush piping inlet valve, WST-V-183.

$\frac{1 . R}{2.15 .96} 6.4 .2 \quad \begin{aligned} & \text { VERIFY the following valve configuration. See Figure } 7 \text { for } \\ & \text { sketch. }\end{aligned}$

Note: Switches WST-HS-140G, WST-HS-141G, and WST-HS-142G operate respectively valves WST-SOV-140G, WST-SOV-141G, and WST-SOV-142G.

\begin{tabular}{|c|c|c|}
\hline DOCUMAT NO. & REvision & maE NO. \\
\hline WHC-SD-WM-ATP-155 & 0 & 25 of 38 \\
\hline
\end{tabular}


INITIAL VALVE LINEUP

\begin{tabular}{||l|l|c|l|l|c|}
\hline SW-V-129 & CLOSED & $\nearrow$ & WST-V-183 & OPEN & $\checkmark$ \\
\hline WST-SOV-140G & $\begin{array}{l}\text { ENERGIZED } \\
\text { (CLOSED) }\end{array}$ & $\checkmark$ & WST-SOV-141G & $\begin{array}{l}\text { ENERGIZED } \\
\text { (CLOSED) }\end{array}$ & $\checkmark$ \\
\hline WST-SOV-142G & $\begin{array}{l}\text { ENERGIZED } \\
\text { (CLOSED) }\end{array}$ & $\checkmark$ & V-VAC-BREAKER & CLOSED & $\checkmark$ \\
\hline
\end{tabular}

$\frac{x}{2-15 \cdot 69}$

6.4.3 RECORD the following:

Reading on flow totalizer, $F Q I-A N-1$, for AN farm service water flocated in the 242-A Evaporator. K\& $\mathrm{C}$ z/s5/76

FQI-AN-1 total 5,3997 gallons

Reading on the flowmeter/totalizer located in the water flush system piping (see figure 7 ).

Total $201.0^{12}$ gallons $2262 n$

Note: Flush the mixer pump inlet screen first.

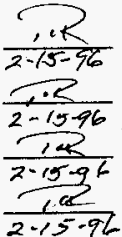

6.4.4 DE-ENERGIZE (OPEN) WST-SOV-142G.

6.4.5 OPEN SW-V-129.

6.4.6 START stopwatch.

6.4.7 After about 1 minute, RECORD system pressure from

cal ibrated pressure gauge.

Water pressure while flushing inlet screen $135^{\prime 5^{-}}, 30$

$\frac{\pi \cdot 4}{2 \cdot 15.96}$

6.4.8 After approximately 4 minutes have elapsed, ENERGIZE (CLOSE) WST-SOV-142G.

$\frac{\pi \cdot 2}{2-15-76}$

\section{4 .9}

STOP stopwatch.

Time Elapsed - Inlet Screen Flush

$\frac{\pi}{2 \cdot 15-96}$

\subsubsection{RECORD the following:}

Reading on flow totalizer, FQI-AN-1, for AN farm service water flocatod in the-242-A-Evaporatort. KAC z/15/96

FQI-AN-1 total $x H$ galions

Reading on the flowmeter/totalizer located in the water flush system piping (see Figure 7).

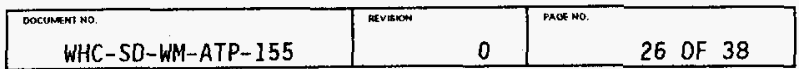


Total $206^{.0^{T}}$ gallons $250.1^{2}=$

$\frac{2.2}{2+15-96}$

6.4.11 RECORD pressure shown on the calibrated pressure gauge.

Service Water Pressure to Flush System $135.5^{5}$ psig

Note: Flush one pump discharge nozzle.

$\overbrace{\frac{112-15}{2-15}}$

6.4.12 DE-ENERGIZE (OPEN) WST-SOV-141G.

$\frac{2+1}{2-1096}$

6.4.13 START stopwatch.

$\frac{1.2}{2-15-96}$

6.4.14 RECORD pressure shown on calibrated pressure gauge; 2 . Water pressure while flushing 133.5 psig

, 6.4.15 After 30 seconds have elapsed, ENERGIZE (CLOSE) 2.15.96 WST-SOV-141G.

$\frac{T .2}{2.15 .94} 6.4 .16$ STOP stopwatch. RECORD time elapsed below. $\frac{1+R}{2-15-96}$

6.4.17 RECORD the following:

Reading on flow totalizer, FQI-AN-1, for AN farm service water floc in 242-A-Evaporator). KसC 2/15/96

FQI-AN-1 total

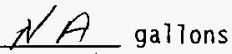

Reading on the flowmeter/totalizer located in the water flush system piping (see Figure 7).

Total $2.0^{12^{\top}}$ gallons $266.2=$

Note: Flush the other pump discharge nozzle.

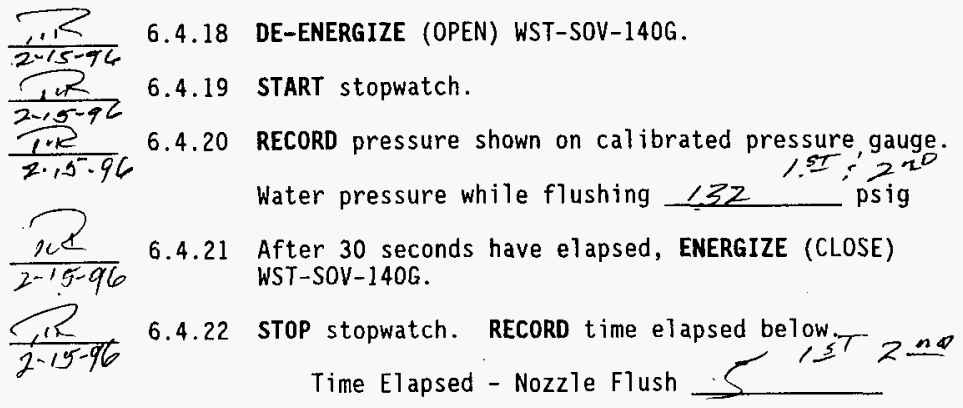

\begin{tabular}{|c|c|c|c|}
\hline $\begin{array}{c}\text { Doccinati No. } \\
\text { WHC-SD-WM-ATP-155 }\end{array}$ & 0 & & 27 OF 38 \\
\hline
\end{tabular}




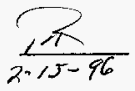

\subsubsection{RECORD the following:}

Reading on flow totalizer, FQI-AN-1, for AN farm service water flocate in $242-A$ Evaporator) $K \Delta C$ \&/15/96

FQI-AN-1 total $5140 \geq \geq$ gallons

Reading on the flowmeter/totalizer located in the water flush system piping (see Figure 7).

Total $z 26.2$ gallons

Note: The following steps prepare for hose detachment.
$\frac{15}{x-15-96}$
6.4.24 CLOSE AN farm water supply valve, SW-V-129.
$\frac{-12}{2-19=96}$
6.4 .25
DE-ENERGIZE WST-SOV-140G, WST-SOV-141G and WST-SOV-142G.
VERIFY the following valve configuration.

VALVE LINEUP AT BEGINNING OF HOSE DETACHMENT PROCEDURE

\begin{tabular}{|c|c|c|c|c|c|}
\hline$S W-V-129$ & CLOSED & 2 & WST-V-183 & OPEN & 4 \\
\hline WST-SOV-140G & $\begin{array}{l}\text { DE-ENERGIZED } \\
\text { (OPEN) }\end{array}$ & & WST-SOV-141G & $\begin{array}{l}\text { DE-ENERGIZED } \\
\text { (OPEN) }\end{array}$ & $\longleftarrow$ \\
\hline WST-SOV-142G & $\begin{array}{l}\text { DE-ENERGIZED } \\
(0 P E N)\end{array}$ & & V-VAC-BREAKER & CLOSED & 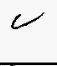 \\
\hline
\end{tabular}

$\frac{112}{2.15 .96}$

6.4.26 RECORD pressure shown on the calibrated pressure gauge.

Flush System Pressure

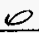
psig

Note: The following step breaks the vacuum on the upper portion of the water flush system. Opening valve V-VAC-BREAKER, located at the piping's highest elevation, will allow air to rush in thru the vacuum breaker and relieve backpressure in the flush system, with the result that water in the above-ground piping will drain into the tank.

$\frac{1,2}{2-15-96}$

6.4 .27 OPEN Valve V-VAC-BREAKER.

$\frac{\sqrt{12}}{2-13-96}$

6.4.28 After sufficient time for the water to drain, CLOSE valves V-VAC-BREAKER and WST-V-183.

TR 6.4.29 VERIFY that the pressure shown on the calibrated pressure $2 \cdot 15 \cdot 96$ gauge is approximately 0 psig.

$\frac{C, 1 K}{2.15-96} 6.4 .30 \begin{aligned} & \text { DETACH and set aside interface piping installed between raw } \\ & \text { water supply, SW-V-129, and water flush inlet piping. }\end{aligned}$

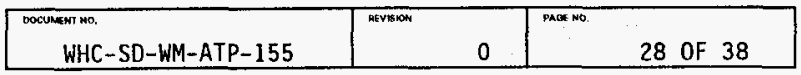


indication as indicated on ANN-008. (Record 0 for motor speed, power, and current)

Note: The water flush system solenoid valves close when energized. The valves should always be shut during mixer pump operation as they provide an extra barrier against waste backflow. See Figure 7.

$\frac{1,8}{2-15-96}$

6.5.9 ENERGIZE (CLOSE) solenoid valves WST-SOV-140G, WST-SOV$141 G$, and WST-SOV-142G.

NOTE: The following steps prepare the VFD for mixer pump start with an operating speed of $400 \mathrm{rpm}$.

6.5.10 PRESS AND RELEASE the VFD S.T.0.P. OFF pushbutton.

$2 \times 1.96$

$\frac{1+5}{2-15-96}$

$\frac{\sqrt{12}}{2 \cdot 15 \cdot 96}$

$\frac{\sqrt{18}}{2-15-96}$

$\frac{1.5}{2-15-96}$

$\frac{\pi}{2.15 \cdot 96}$
6.5.11 PRESS AND RELEASE the VFD S.T.O.P. SPEED SET pushbutton.

6.5.12 PRESS AND RELEASE the VFD S.T.O.P. 10S pushbutton.

6.5.13 PRESS AND HOLD the VFD S.T.O.P. UP ARROW pushbutton unti1 the screen indicates "S.T. 0400.00 ".

6.5.14 PRESS AND RELEASE the VFD S.T.0.P. SPEED pushbutton and verify that the VFD S.T.O.P. indicates "S.P. 0000.00".

6.5.15 VERIFY that all VFD S.T.O.P. LED's are off.

NOTE: This test is a "bump" and therefore of short duration (approximately 30 seconds). READ AND PREPARE FOR THE NEXT 9 STEPS BEFORE CONTINUING THE PROCEDURE.

NOTE: Operating limits have been programmed into the mixer pump strain, vibration, and motor temperature digital indicators. The values are given in Appendix A. If limits are exceeded, interlocks will shut off the pump and alarms located in ANN-008 will annunciate. If 1 imits are exceeded, record on a TEST EXCEPTION sheet.

$\prod_{2,15-96}^{15}$

6.5.16 START stopwatch.

6.5.17 PRESS AND RELEASE the VFD S.T.O.P. HAND pushbutton and

$\frac{212}{z-15-96}$ verify that the S.T.O.P. Screen value increases from "S.P. 0000.00 " to "S.P. 0400.00 ".

$\frac{112}{2-15-94}$

$\frac{2+12}{2-15 x}$

6.5.18 VERIFY the VFD S.T.O.P. RUN LED is illuminated.

6.5 .19

PRESS AND RELEASE the VFD S.T.O.P. M AMPS pushbutton. Record this value on the MIXER PUMP "BUMP" TEST DATA SHEET

$\frac{124}{2-15.96}$

6.5 .20

PRESS AND RELEASE the VFD S.T.0.P. KILOWATTS pushbutton. Record this value on the MIXER PUMP "BUMP" TEST DATA SHEET

\begin{tabular}{|c|c|c|}
\hline DOCISMAKT MO. & PEVISIDW & paOF no. \\
\hline WHC-SD-WM-ATP-I55 & 0 & 30 of 38 \\
\hline
\end{tabular}




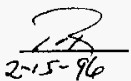

6.5 .21

$\frac{\pi R}{2 \sqrt{15-96}}$

$\frac{2 \cdot R}{2+15-96}$

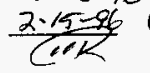

6.5.22 PRESS AND RELEASE the VFD S.T.0.P. OFF pushbutton.

6.5 .24

$\frac{\pi}{2-15.96}$

6.5 .25

$\frac{\pi+8}{2-15-96}$

6.5 .26

$\frac{2 \pi}{2-15-96}$

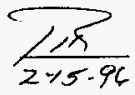

Record the values of mixer pump strain, vibration, and

motor temperature on the MIXER PUMP "BUMP" TEST DATA SHEET.

VERIFY the VFD S.T.O.P. indicates "S.P. 0000.00".

STOP stopwatch. RECORD time elapsed below.

Duration of mixer pump operation

PUSH IN the WST-VFD-107 EMERGENCY STOP push-pu1l operator on the mixer pump $75 \mathrm{HP}$ VSD cabinet.

DE-ENERGIZE solenoid valves WST-SOV-140G, WST-SOV-141G, and WST-SOV-142G.

6.5.27 On the MIXER PUMP "BUMP" TEST DATA SHEET, RECORD the values of mixer pump strain, vibration, and motor temperature shown on TB-1A. RECORD motor moisture indication as indicated on ANN-008. (Record 0 for motor speed, power, and current)

6.5.28 RECORD values for the following: $x$ times

Tank AN-107 primary tank pressure.

Read red pen on chart recorder. (WST-PR-107)

Tank AN-107 peak primary tank pressure during pump bump

Read red pen on chart recorder. (WST-PR-107) -2.1.

ventilation flammuble gas (LFL) and arganic

$K \perp d C_{106} 107$ - AN farm primary stack $N_{31}$ concentration

${ }_{21}{ }_{15} / 96$ (requires an Industrial Hygenist) Record resulto on J.5.

N/A KAC 6.5.29 OPEN all breakers in EDS-DP-108 panelboard, except for: च/5/96

- Main Breaker

- CKT \#8: WST-XFMR-107 15 KVA Transformer

N/A R2C 6.5.30 OPEN all breakers in EDS-DP-109 panelboard, except for: 2/15/96. Main Breaker

- CKT \#6: Camera Equipment, Building 241-AN-274

- CKT \#8: Camera Equipment - Field

- CKT\#1 -CKT\#II CKT\#12 KHC 2/15/96

$\frac{126}{2-15 \div 96}$

6.5.31 ENSURE building 241-AN-274 is returned to a safe and stable state before ending test.

\begin{tabular}{|c|c|c|}
\hline Doccusest No. & REVyis:ont & PAOE NG \\
\hline WHC-SD-WM-ATP-155 & 0 & 31 of 38 \\
\hline
\end{tabular}


75 HP MIXER PUMP FIELD ACCEPTANCE -

MIXER PUMP "BUMP" TEST DATA SHEET
HNF

WHE-SD-WM-ATR-155

Rev. 0

Page B-15

DATE $z-15-96$

5N-HAZLETON TYPE "SSB/MIXING" PUMP, SERIAL NO. N-20801

\begin{tabular}{|c|c|c|c|c|c|c|c|}
\hline $\begin{array}{l}\text { Time / Recorder } \\
\text { Initials }\end{array}$ & $\begin{array}{l}\text { Motor } \\
\text { Speed } \\
\text { (rpm) }\end{array}$ & $\begin{array}{l}\text { Motor } \\
\text { Power } \\
\text { (kH) }\end{array}$ & $\begin{array}{l}\text { Motor } \\
\text { Current } \\
\text { (amps) }\end{array}$ & $\begin{array}{c}\text { Pump } \\
\text { vibration } \\
\text { (in/s) }\end{array}$ & $\begin{array}{l}\text { Motor } \\
\text { Temp } \\
\left({ }^{\circ} \circ\right)\end{array}$ & $\begin{array}{l}\text { Strain } \\
\text { Unbalance } \\
\text { Load } \\
\text { (1b) } \\
\end{array}$ & $\begin{array}{l}\text { Motor } \\
\text { Moisture } \\
\text { (yes/no) }\end{array}$ \\
\hline $1455^{2} \longrightarrow$ & 0 & 0 & 0 & .26 & 107.7 & -35 & No \\
\hline $15 \times 5=$ & $1 / 80$ & $\frac{1.3}{2 z^{2} \cdot \sqrt{12}}$ & 27.1 & OVERSSW & 106.0 & -72 & No \\
\hline $16: 20 \sin 2$ & 400 & 1.3 & 22.6 & overseale & 107,6 & -23 & NO \\
\hline & & & & & & & \\
\hline & & & & & & & \\
\hline & & & & & & & \\
\hline
\end{tabular}

1. Tank 241-AN-107 estimated specific gravity $=1.4$.

Data Recorders: Print name, Sign name, Date, 215196 MA. Lerhban $z-15-96$

Pump cognizant Engineer ACl. Lestictar

Test Director 
HNF-SD-WM-ATR-155 Rev. 0 Page C-1 of C-4

APPENDIX C

Test $\log$ 
HNF-SD-WM-ATR-155 Rev. 0 Page C-2 of C-4

\begin{tabular}{|c|c|c|}
\hline & & Recorder: GA Leshikar \\
\hline Date & Step \# & Comments \\
\hline $10 / 26 / 95$ & 6.1 .6 & $\begin{array}{l}\text { Problem: Circuit breaker instantaneously shuts down the } \\
1 \text { HP rotation motor when Jog Switch SW1 is activated. } \\
\text { Resolution: Circuit breaker is dial type, } 3 \text { amp rating, } \\
\text { instantaneous trip. Motor amperage approximately } 2 \\
\text { amps. Note that instantaneous type breaker is not } \\
\text { optimal for motor start-up current. Dial was turned } \\
\text { down too low so motor instantly tripped out. Per NEC } \\
430-52 \text {, Part A, Exception (pg. 70-406), it is } \\
\text { permissible to dial circuit breaker up to } 1100 \% \text { of full } \\
\text { load amps. Attempted at } 700 \% \text {, breaker sti11 tripped. } \\
\text { Attempted at } 900 \% \text {, no breaker trip. Wi11 keep at new } \\
\text { setting. }\end{array}$ \\
\hline $10 / 27 / 95$ & 6.1 .6 & $\begin{array}{l}\text { Problem: l HP rotation motor makes loud "clacking" } \\
\text { noise when energized. } \\
\text { Resolution: Rotation motor is vertically mounted, } \\
\text { Totally Enclosed Fan Cooled (TEFC) type, with fan on } \\
\text { top which is covered by a cylindrical sheet metal } \\
\text { guard. After watching personnel balance themselves } \\
\text { while "clambering" over obstacles in the crowded pit, } \\
\text { my suspicion is that someone applied a bit too much } \\
\text { hand pressure to the sheet metal fan guard on top the } \\
\text { motor and slightly "dented" in the guard. The fan } \\
\text { blades then were contacting metal which accounted for } \\
\text { the loud "clacking" noise. Fixing the problem was a } \\
\text { simple matter of the electrician partially removing the } \\
\text { fanguard and "denting" it back to it original } \\
\text { configuration. }\end{array}$ \\
\hline $10 / 27 / 95$ & & $\begin{array}{l}\text { The bar (gear locking device) used by Hazleton to lock } \\
\text { the pump turntable in place during transit has been } \\
\text { taped to a piece of unistrut on the pit wall. }\end{array}$ \\
\hline $10 / 27 / 95$ & 6.2 & $\begin{array}{l}\text { The Iowa State / Ames Laboratory engineer took } \\
\text { ultrasonic transducer data. Apparently it was } \\
\text { disappointing. He will take the data back to Ames for } \\
\text { detailed analysis and return later to obtain new } \\
\text { baseline data. }\end{array}$ \\
\hline $10 / 30 / 95$ & & $\begin{array}{l}\text { Al1 mixer pump instruments calibrated except for } \\
\text { vibration monitor. Vibration monitor is giving "out- } \\
\text { of-range" signal. Need to troubleshoot. }\end{array}$ \\
\hline
\end{tabular}


HNF-SD-WM-ATR-155 Rev. 0 Page C-3 of C-4

\begin{tabular}{|c|c|c|}
\hline & & Recorder: GA Leshikar \\
\hline Date & Step \# & Comments \\
\hline $11 / 17 / 95$ & 6.2 & $\begin{array}{l}\text { The lowa State / Ames Laboratory engineer, Lance, } \\
\text { returned with new equipment to take more ultrasonic } \\
\text { transducer data today. The new data turned out to be } \\
\text { inconsistent. Sometimes the returns showed that the } \\
\text { signals penetrated the waste a good distance and other } \\
\text { times the returns showed nothing. Lance thinks that he } \\
\text { has a faulty amplifier. He plans to return again to } \\
\text { take more data, hopefully before the mixing test } \\
\text { commence. }\end{array}$ \\
\hline $11 / 17 / 95$ & 6.4 .3 & $\begin{array}{l}\text { Engineer, GA Leshikar, insists that AN farm raw water } \\
\text { meter / flow totalizer, FQI-AN-1, outputs a signal to } \\
\text { the 242-A Evaporator for indication. This is supported } \\
\text { by drawings H-2-71944, H-2-71968, and H-14-021801. PIC } \\
\text { - DW Vandyke, tank farm maintenance crew (i.e. people } \\
\text { who have been in the water service pit), and Evaporator } \\
\text { shift manager insist that AN farm raw water meter is } \\
\text { local indication only. ? }\end{array}$ \\
\hline $11 / 17 / 95$ & 6.4 & $\begin{array}{l}\text { Problem: Solenoid valves are not closing properly. } \\
\text { Description: When the mixer pump's water flush system } \\
\text { is pressurized and all } 3 \text { solenoid valves are closed, } \\
\text { there should be no water flow into AN-107. Readings } \\
\text { taken from both the AN farm raw water flow totalizer } \\
\text { and the temporary in-line flow totalizer indicated that } \\
\text { there was flush water flow into the tank even though } \\
\text { all } 3 \text { solenoid valves were energized (closed) } \\
\text { Flowrate was approximately } 8 \text { gpm, no matter whether the } \\
\text { solenoid switches were on or off. }\end{array}$ \\
\hline $11 / 20 / 95$ & 6.4 & $\begin{array}{l}\text { Solenoid valve troubleshooting: It was quickly } \\
\text { discovered that the switches for the solenoids, mounted } \\
\text { on the electrical cabinet door, were not wired. } \\
\text { Therefore the solenoid valves could not be energized } \\
\text { which explains why flush water flowrate was unchanging } \\
\text { no matter if the switches were on or off. }\end{array}$ \\
\hline
\end{tabular}


HNF-SD-WM-ATR-155 Rev, 0 Page C-4 of C-4

\begin{tabular}{|c|c|c|}
\hline & & Recorder: GA Leshikar \\
\hline Date & Step \# & Comments \\
\hline $11 / 21 / 95$ & & $\begin{array}{l}\text { Reason for vibration monitor "out-of-range" signal was } \\
\text { determined (with pump at rest). Wiring was corrected, } \\
\text { however, the vibration monitor shows an "at-rest" } \\
\text { reading of } 0.27 \text { in/s. } \\
\text { Reason: As discovered in the shop tests of the mixer } \\
\text { pump, the Hazleton-supplied mixer pump instrumentation } \\
\text { was consistently wired strangely in that one conductor } \\
\text { and the shield were used to transmit sensor signals. } \\
\text { When the vibration cable was replaced in July i95, the } \\
\text { electrician connected the cable leads to the } \\
\text { accelerometer according to normally accepted practice, } \\
\text { which is to use two conductors to transmit sensor } \\
\text { signals and attach the shield for grounding purposes. } \\
\text { Because this wiring is also grounded at the instrument } \\
\text { cabinet, a current loop was apparently created which } \\
\text { affected the sensors output. The solution was to } \\
\text { remove the instrument cabinet ground. None of this was } \\
\text { necessary with the other mixer pump instrumentation } \\
\text { since it still uses the one conductor and shield } \\
\text { configuration. }\end{array}$ \\
\hline $11 / 30 / 95$ & 6.4 & $\begin{array}{l}\text { Water flush system test performed again. System worked } \\
\text { as advertised. Solenoid valves operated properly. }\end{array}$ \\
\hline $12 / 5 / 95$ & 6.5 & $\begin{array}{l}\text { Mixer pump bump performed. Test Exceptions were } \\
\text { written for vibration indicator overscale and for video } \\
\text { monitor "snow" (images from the in-tank camera) when } \\
\text { the VFD operated the mixer pump. Camera video was } \\
\text { recorded on a VCR tape. }\end{array}$ \\
\hline $1 / 10 / 96$ & 6.2 & $\begin{array}{l}\text { Professor Martin from Iowa State / Ames Laboratory was } \\
\text { able to fix the ultrasonic test equipment. He then } \\
\text { obtained baseline data at } 10^{\circ} \text { increments thru the } \\
\text { defined } 167^{\circ} \text { mixing range. }\end{array}$ \\
\hline $2 / 15 / 96=$ & 6.5 & $\begin{array}{l}\text { Troubleshooting performed on vibration indicator } \\
\text { overscale and video monitor "snow" exceptions. Neither } \\
\text { problem was solved. Some recourse may be possible for } \\
\text { the "snow" problem but no recourse for the faulty } \\
\text { vibration indication problem. }\end{array}$ \\
\hline
\end{tabular}


HNF-SD-WM-ATR-155 Rev. 0 Page D-1 of D-10

\section{APPENDIX D}

Calibration Data 


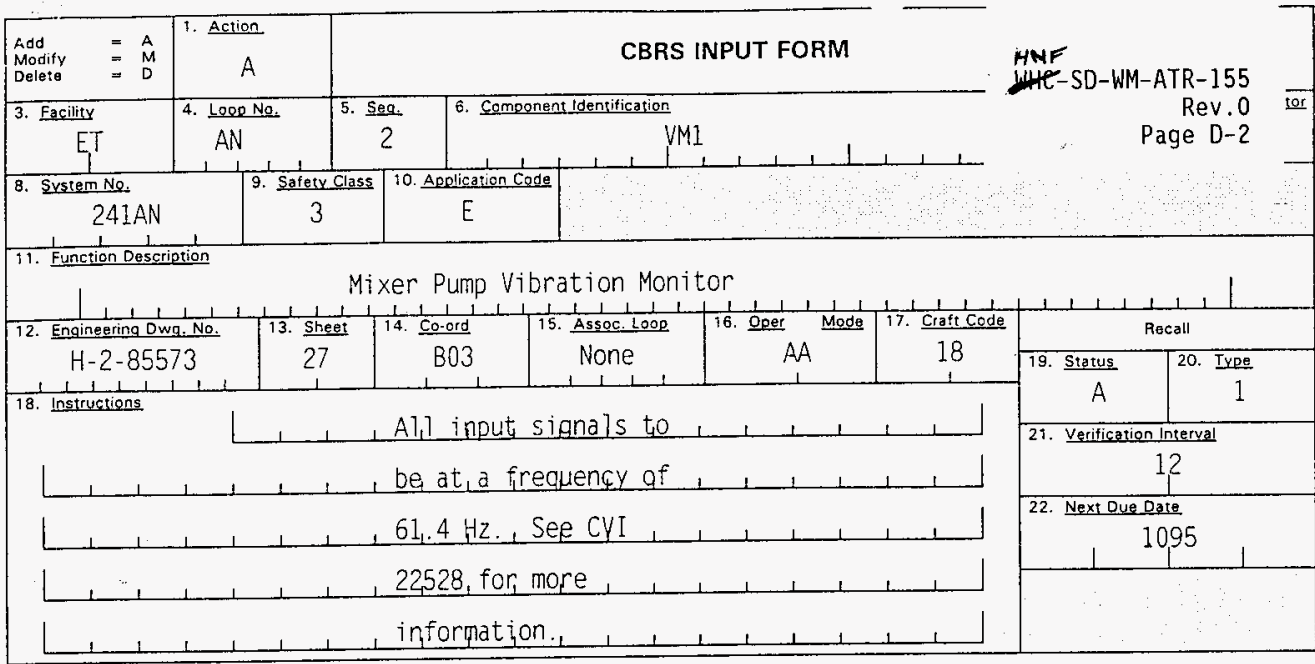

23. Reason: Instrument needs to be calibrated prior to performance of Mixer Pump ATP.

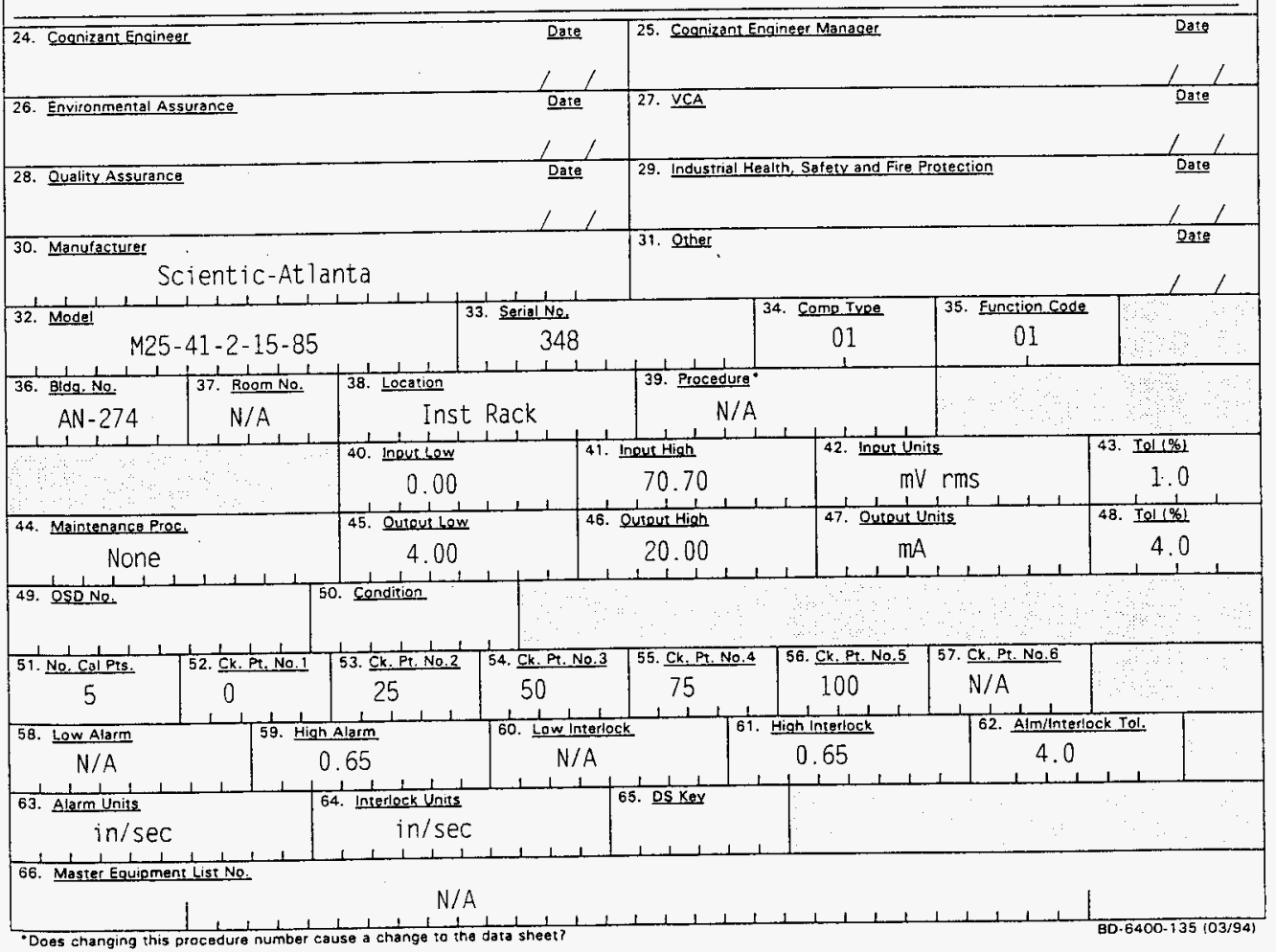


Vibration Indicator VMI

Calibration Data Record Sheet

Alarm/Interlock Setpoint

\begin{tabular}{|c|c|c|c|}
\hline AS FOUND & EXPECTED OUTPUT & MODIFIED (Y/N) & AS LEFT \\
\hline $6.5 \mathrm{~V}$ & $6.5 \mathrm{~V} \pm .1 \mathrm{~V} \mathrm{DC}$ & $\mathrm{N}$ & $6 \mathrm{~V}$ \\
\hline
\end{tabular}

Instrument Span

\begin{tabular}{|c|c|c|c|c|c|c|c|}
\hline PERCENT & $\begin{array}{l}\text { INPUT } \pm 1 \% \\
\text { (mV rms) }\end{array}$ & \multicolumn{3}{|c|}{$\begin{array}{c}\text { EXPECTED OUTPUT (mA) } \\
\text { TOL - TOL + }\end{array}$} & AS FOUND & $\begin{array}{l}\text { IN/OUT } \\
(Y / N) \\
\end{array}$ & AS LEFT \\
\hline 0 & 0.000 & 4.00 & 3.36 & 4.64 & 3.93 & 4 & 3.93 \\
\hline 25 & 17.675 & 8.00 & 7.36 & 8.64 & $-1,89$ & 4 & 7.89 \\
\hline 50 & 35.350 & 12.00 & 11.36 & 12.64 & 11.87 & 4 & 11.37 \\
\hline 75 & 53.025 & 16.00 & 15.36 & 16.64 & 16,05 & if & 6.65 \\
\hline 100 & 70.700 & 20.00 & 19.36 & 20.64 & 19,87 & $L$ & $1 \%, 87$ \\
\hline
\end{tabular}

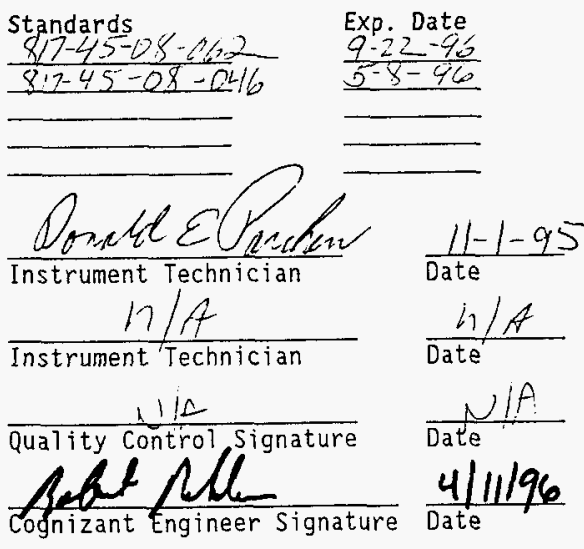

Tolerance

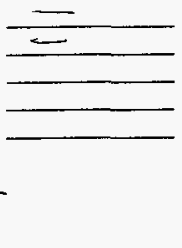




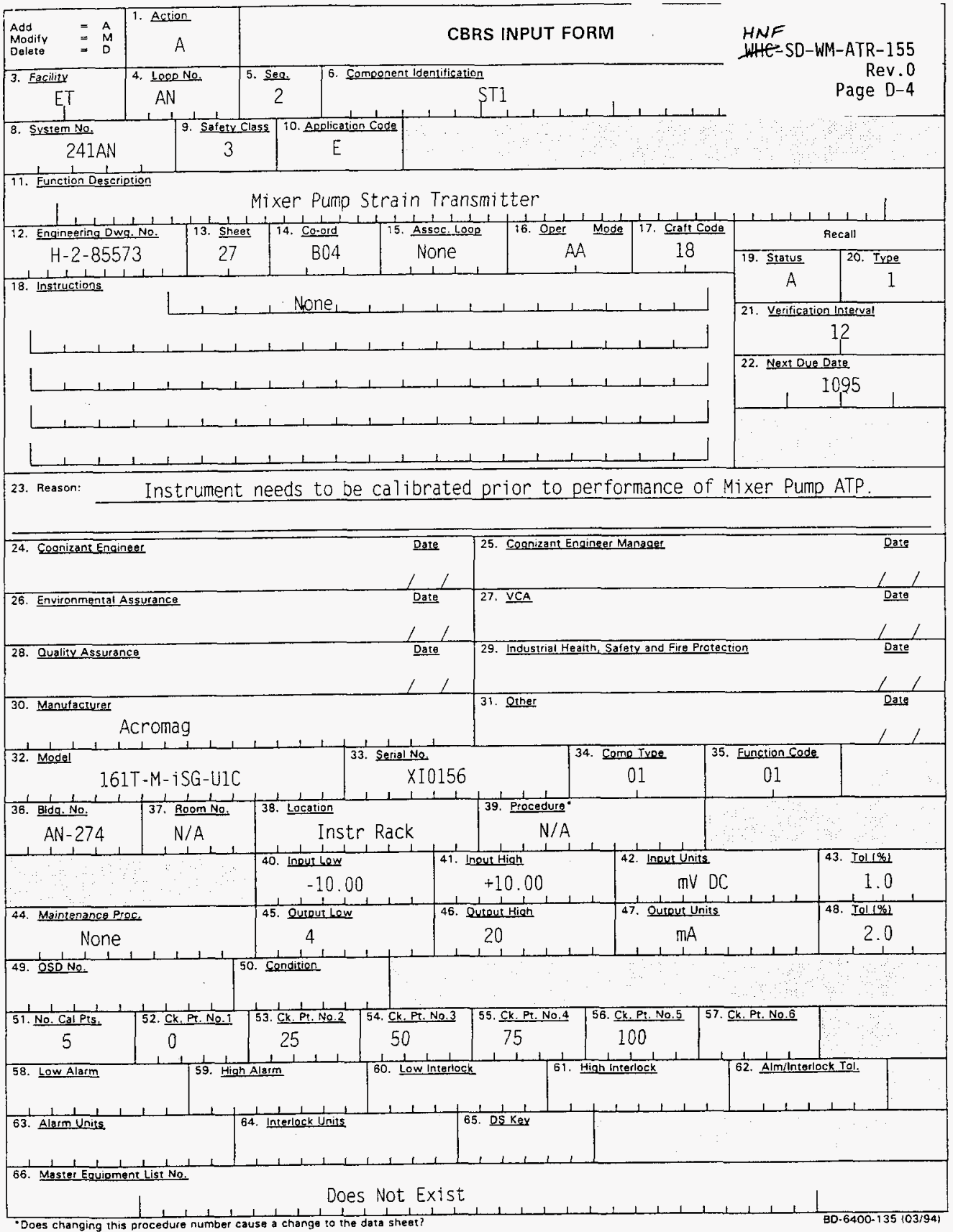


Strain Transmitter STI

d.

Excitation Voltage

\begin{tabular}{|c|c|c|c|}
\hline AS FOUNO & EXPECTEO OUTPUT & MODIFIED $(Y / N)$ & AS LEFT \\
\hline $5.0 \mathrm{~V}$ & $5.0 \mathrm{~V} \pm .1 \mathrm{~V}$ OC & $\mathrm{N}^{\prime}$ & 5.0 \\
\hline
\end{tabular}

Instrument Span

\begin{tabular}{|c|c|c|c|c|c|c|c|}
\hline PERCENT & $\begin{array}{l}\text { INPUT } \pm 1 \% \\
(\mathrm{mV} D C)\end{array}$ & \multicolumn{3}{|c|}{$\begin{array}{c}\text { EXPECTED OUTPUT (mA) } \\
\text { TOL }-\quad \mathrm{TOL}+ \\
\end{array}$} & $\begin{array}{l}\text { AS FOUNO } \\
(\mathrm{mA}) \\
\end{array}$ & $\begin{array}{l}\text { IN/OUT } \\
(\mathrm{Y} / \mathrm{N}) \\
\end{array}$ & $\begin{array}{c}\text { AS LEFT } \\
(\mathrm{mA}) \\
\end{array}$ \\
\hline 0 & -10.00 & 4.00 & 3.68 & 4.32 & 4,62 & Ir & 402 \\
\hline 25 & -5.00 & 8.00 & 7.68 & 8.32 & 3.03 & 11 & 5.03 \\
\hline 50 & 0 & 12.00 & 11.68 & 32 & 10203 & $"$ & 12,03 \\
\hline 75 & 5.00 & 16.00 & 15.58 & 16.32 & 16.05 & _. & 16.05 \\
\hline 100 & 10.00 & 20.00 & 19.68 & 20.32 & 20.04 & " & 20.04 \\
\hline
\end{tabular}

Standards

\section{$817-45-09-046$}

$317-23=0 i-007$

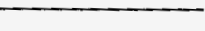

Dh.

Instrument Technician

N/A

Instrument Technician

Nie

Quality Control Signature

Exp. Date

Tolerance
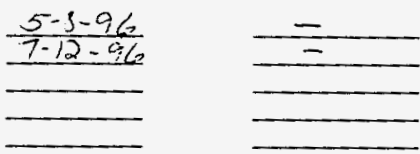

Cognizant Engineer signature

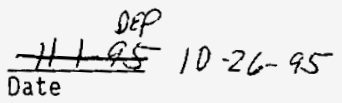

$\frac{N / A}{\text { Date }}$

$\frac{\text { Wate }}{\text { Date }}$

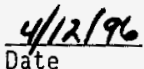




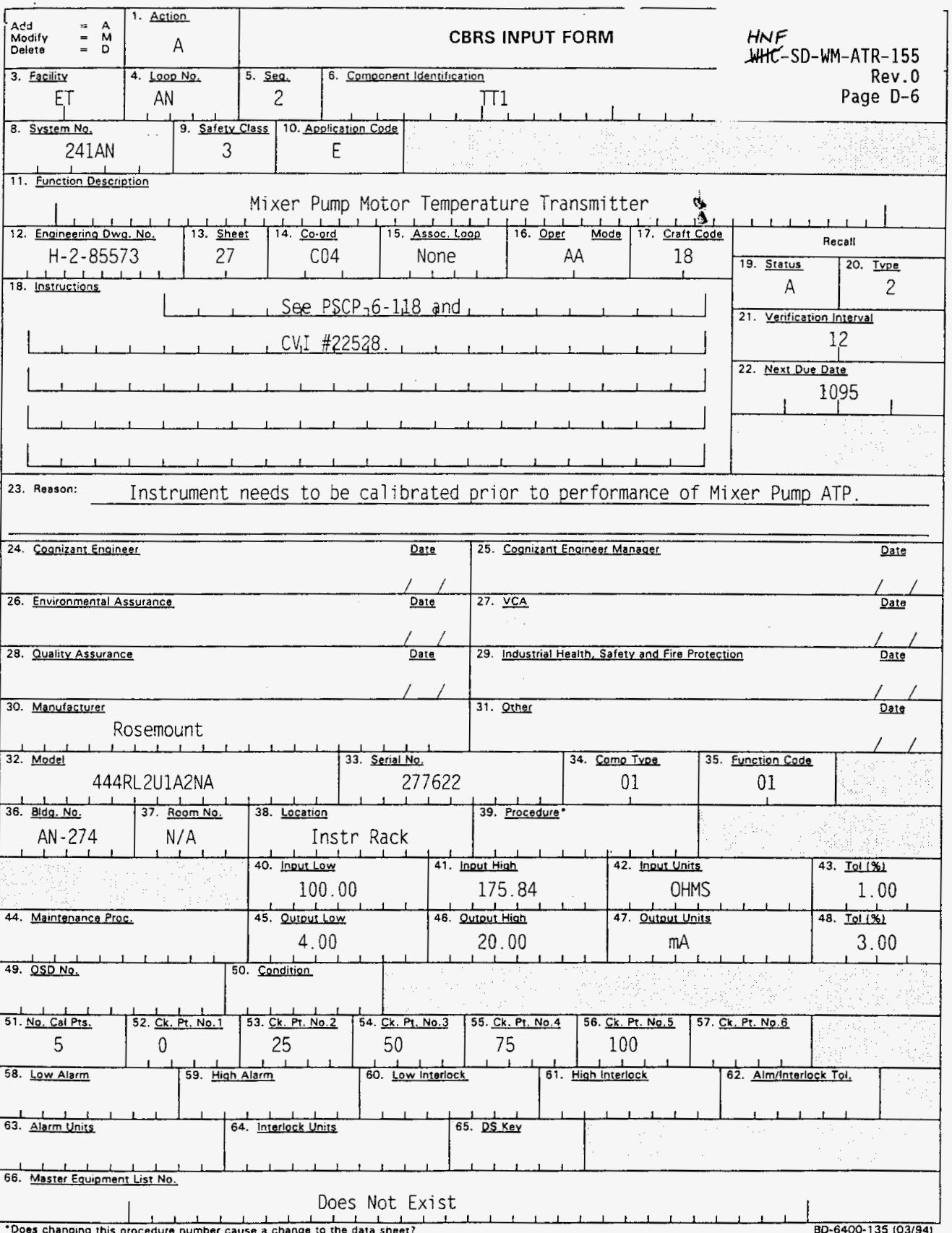


Instrument Span

\begin{tabular}{|c|c|c|c|c|c|c|c|}
\hline PERCENT & $\begin{array}{c}\text { INPUT } \pm 1 \% \\
\text { (OHMS) }\end{array}$ & \multicolumn{2}{|c|}{ EXPECTED OUTPUT } \\
TOL & TOL + & $\begin{array}{c}\text { AS FOUND } \\
(\mathrm{mA})\end{array}$ & $\begin{array}{c}\text { IN/OUT } \\
(\mathrm{Y} / \mathrm{N})\end{array}$ & $\begin{array}{c}\text { AS LEFT } \\
(\mathrm{mA})\end{array}$ \\
\hline 0 & 100.00 & 4.00 & 3.52 & 4.48 & 3.97 & $w$ & 3.97 \\
\hline 25 & 118.96 & 8.00 & 7.52 & 8.48 & 7.89 & 11 & 7.89 \\
\hline 50 & 137.92 & 12.00 & 11.52 & 12.48 & 11.87 & 11 & 11.87 \\
\hline 75 & 156.88 & 16.00 & 15.52 & 16.48 & 15.91 & 11 & 15.91 \\
\hline 100 & 175.84 & 20.00 & 19.52 & 20.48 & 20.03 & 11 & 20.03 \\
\hline
\end{tabular}

Standards

\begin{tabular}{ll}
$\frac{\text { Exp. Date }}{517-63-92-003}$ \\
$\frac{5-9-96}{5-9-96}$ \\
\hline
\end{tabular}

Tolerance

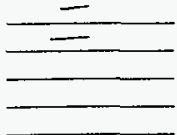

$\frac{\text { Penote }}{\text { Instrument Technician }}$

$\frac{n / A}{\text { Instrument Technician }} \frac{n / A}{\text { Date }}$

$\frac{\mu / A}{\text { Quality Control Signature }} \frac{\mu / A}{\text { Date }}$

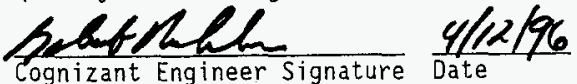




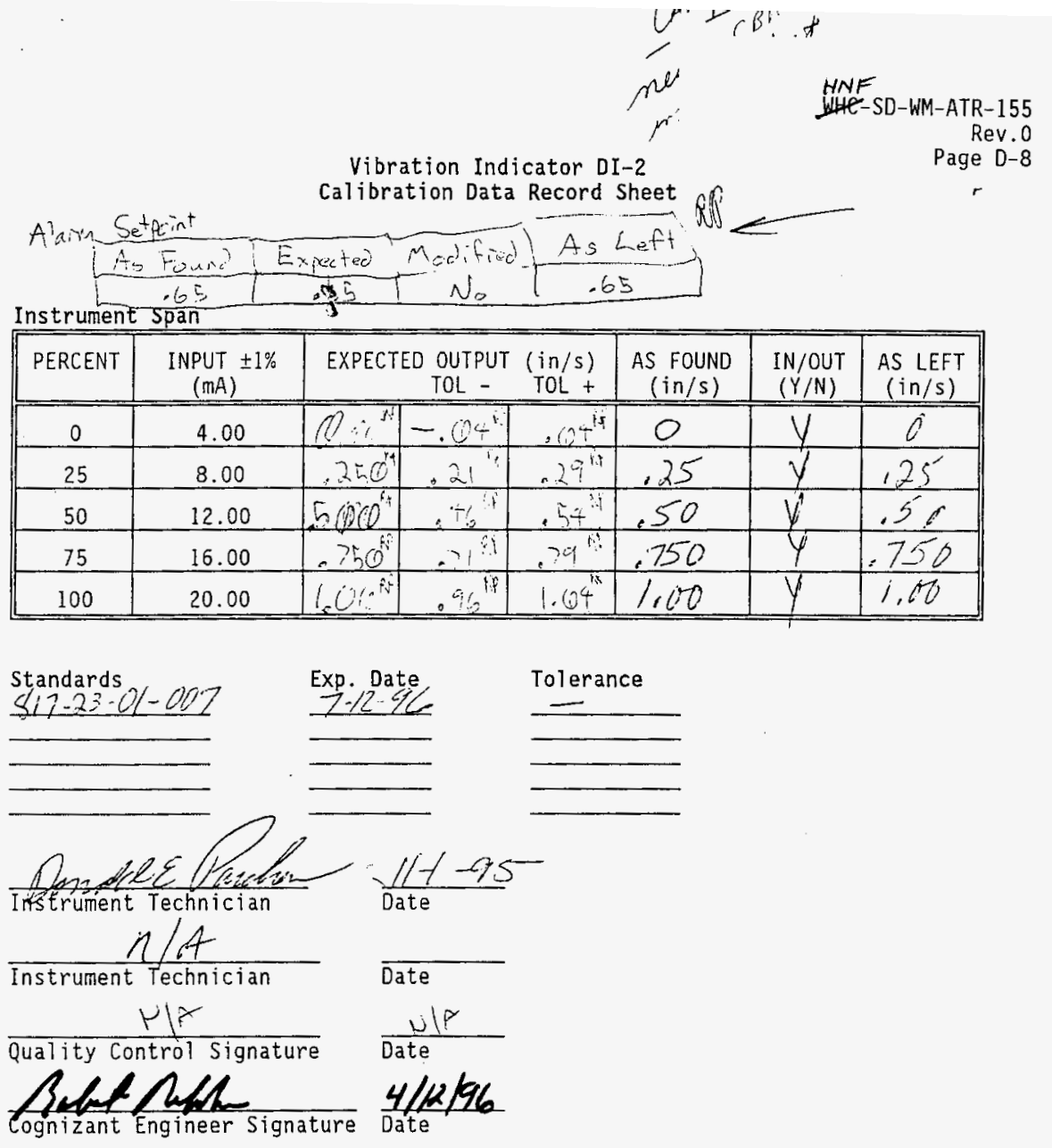


Strain Indicator DI-1

Calibration Data Record Sheet

Low Alarm/Interlock Setpoint

\begin{tabular}{|c|c|c|c|}
\hline AS FOUND (Ibs) & EXPECTED (Ibs) & MODIFIED (Y/N) & AS LEFT (Ibs) \\
\hline-103 & -100 & NO & -100 \\
\hline
\end{tabular}

High Alarm/Interlock Setpoint

\begin{tabular}{|c|c|c|c|}
\hline AS FOUND (Ibs) & EXPECTED (Ibs) & MODIFIED (Y/N) & AS LEFT (Tbs) \\
\hline \hline$C Q$ & 100 & $N$ & $10 O$ \\
\hline
\end{tabular}

Instrument Span

\begin{tabular}{|c|c|c|c|c|c|c|c|}
\hline PERCENT & $\begin{array}{l}\text { INPUT } \pm 1 \% \\
(\mathrm{~mA} \mathrm{DC})\end{array}$ & \multicolumn{3}{|c|}{$\begin{array}{c}\text { EXPECTED OUTPUT (lbS) } \\
\text { TOL - TOL + }\end{array}$} & $\begin{array}{l}\text { AS FOUND } \\
\text { (1bs) }\end{array}$ & $\begin{array}{l}\text { IN/OUT } \\
(Y / N)\end{array}$ & $\begin{array}{c}\text { AS LEFT } \\
\text { (1 } \mathrm{bs} \text { ) }\end{array}$ \\
\hline 0 & 4.00 & -2000 & -2160 & -1840 & -1999 & y & -1990 \\
\hline 25 & 8.00 & -1000 & -1160 & -840 & -1003 & $y$ & -1603 \\
\hline 50 & 12.00 & 0000 & -160 & 160 & -5 & $\bar{y}$ & -5 \\
\hline 75 & 16.00 & 1000 & 840 & 1160 & 996 & $y$ & 996 \\
\hline 100 & 20.00 & 2000 & 1840 & 2160 & 1996 & 4 & 1996 \\
\hline
\end{tabular}

Standards

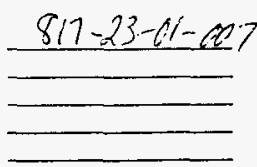

Exp. Date

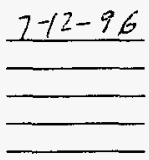

$\frac{11-1-96}{\text { Date }}$

instrument Technician

Instrument Technician

$\mu / \curvearrowright$

Quality Control Signature

Best Nefh

Cognizant Engineer Signature $\frac{11-1-96}{\text { Date }}$

$\frac{N \text { ire }}{\text { Date }}$

$4 / 12 / 16$
Tolerance

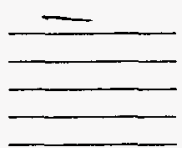


Temperature Indicator $0 I-3$

Calibration Data Recard Sheet

Alarm/Interlock Setpoint

\begin{tabular}{|c|c|c|c|}
\hline AS FOUND $\left({ }^{\circ} \mathrm{F}\right)$ & EXPECTED $\left({ }^{\circ} \mathrm{F}\right)$ & MODIFIED $(\mathrm{V} / \mathrm{N})$ & AS LEFT $\left({ }^{\circ} \mathrm{F}\right)$ \\
\hline $200^{\circ} /$ & 200.00 & NO & $200^{\circ}$ \\
\hline
\end{tabular}

Instrument Span

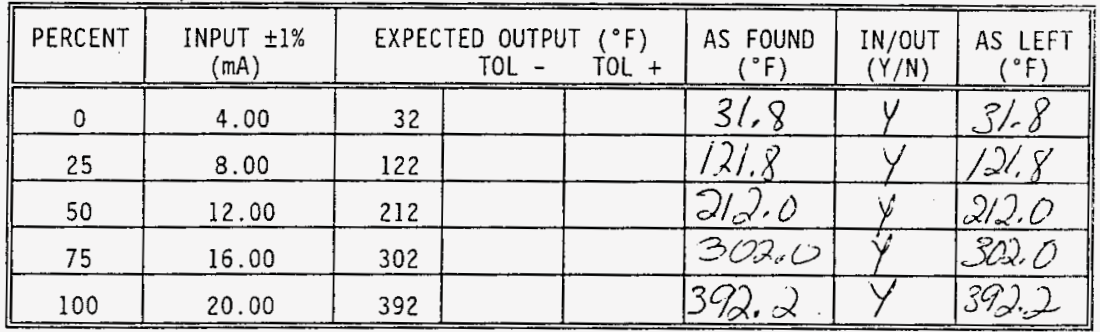

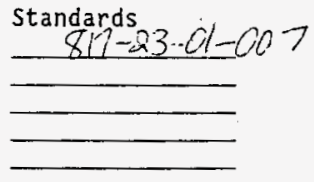

Exp. Date

$-7-12-96$

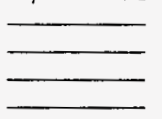

Tolerance

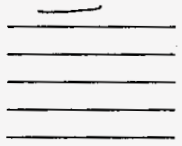

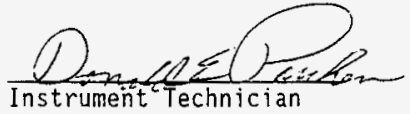

Instrument Technician

$r \mid A$

Instrument Technician

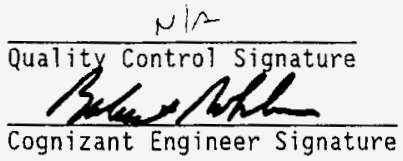

$\frac{11-1-25}{\text { Date }}$

$\frac{N / A}{\text { Date }}$ $\frac{M i s}{\text { Date }}$

$\frac{4 / 12 / 86}{\text { Date }}$ 